九州大学学術情報リポジトリ

Kyushu University Institutional Repository

\title{
Succession of Inoceramus in the Upper Cretaceous of Southwest Japan
}

Noda, Masayuk i

Wasada Junior High School, Oita

https://doi.org/10.5109/1544175

出版情報：九州大學理學部紀要：Series D, Geology. 23 (2)，pp.211-261，1975-11-25. Faculty of Science, Kyushu University バージョン:

権利関係 : 
Mem. Fac. Sci., Kyushu Univ., Ser. D, Geol., Vol. XXIII, No. 2, pp. 211-261, text-figs. 1-22, tables, 1-21, pls. 32-37, November 25, 1975

\title{
Succession of Inoceramus in the Upper Cretaceous of Southwest Japan
}

\author{
Masayuki NODA
}

\begin{abstract}
To make clear the chronological change of Inoceramus species in the Upper Cretaceous sequences, I have examined numerous specimens which were successively collected from the Onogawa and the Uwajima Group in Southwest Japan. Another sample from the Futaba Group, Northeast Japan, is added as supplementary material.

Selected characters are quantitatively and statistically examined on these samples. As a result I attempt to know the morphological relation of the successive samples and consider the infraspecific subdivision.

Inoceramus hobetsensis seems to show chronoclines in the Middle Turonian sequence. In the Upper Turonian it is replaced by Inoceramus teshioensis which is not directly related to it. Inoceramus teraokai of probably labiatus stock occurs together with $I$. hobetsensis in the lower part of Middle Turonian but has no representatives of its descendants in the higher sequences of the examined areas. In the Coniacian Inoceramus uwajimensis occurs characteristically, showing an enlarging extent of variation as the sequence goes upward. There is probably no relation between $I$. teshioensis and I. uwajimensis. The relation of $I$. uwajimensis with Inoceramus mihoensis of the next higher substage is open to question.
\end{abstract}

\section{Introduction}

Species of Inoceramus (s. 1.) are important for Mesozoic stratigraphy and paleontology. As to the Cretaceous species of Inoceramus from Japan a few species were described by YokoYama (1890), Jimbo (1894), YehaRA (1924) and YABE and NAGAO (1925) together with other fossils. The first comprehensive study of this group was "A monograph of the Cretaceous Inoceramus of Japan" by NAGAO and MATSUMOTO $(1939,1940)$. Since then, some species have been newly added or revised by Matsumoto (1957), Matsumoto in TAkaI and Matsumoto (1961), Matsumoto and Ueda in Ueda (1962), Matsumoto and Noda (1968), Tanabe (1973), Noda (1974) and Matsumoto and Noda (1975).

In the meanwhile, Matsumoto $(1959,1969)$ established a scheme of biostratigraphic division of the Upper Cretaceous in Japan in means of ammonite and Inoceramus. His zonation is at present much valuable as a reference scale not only for Japan but also for the Circum-Pacific region.

NAGAo and MATSUmoto (1939, 1940) have distinguished several species groups, recognized presumably evolutionary series within respective groups and described the extent of variation of the species.

Manuscript Received July 7, 1975.

Masayuki NodA: Wasada Junior High School, ōita. 
Outside Japan, HeINTZ (1932) and SEITZ (1961, 1965, 1967, 1970) divided Inoceramus (s. 1.) to a number of genera and subgenera, and established or emended many species and subspecies. There are, however, many intermediate or transitional forms among their species.

Since 1940 the definition of species based on new systematics and the analysis of the specific characters by statistical methods have been taken up as an important matter of biology.

The biometrical and statistical methods in paleontology had been already applied by Oinomikado (1936) and Kotaka (1953) in Japan. HaYAmi (1969) and HAYAMI and MATSUKUMA (1971) mentioned the significance to apply the concept of new systematics and the method of statistics for palaeontology quoting some concrete examples. Furthermore, HAYAMI (1973) attempted to interpret a biostratigraphic zone from a viewpoint of modern genetics.

While I am studing the Inoceramus biostratigraphy of the Upper Cretaceous of Southwest Japan, I meet with difficulty in the zonation for the reason of considerable variation of a species including various grades of transitional forms between different horizons, intermediate forms at a certain horizon and coexistence of two different zonal indices in one bed.

The purpose of the present study is to get concrete data for making clear the succession and chronological change of Inoceramus in the Upper Cretaceous sequences of Southwest Japan. For this purpose numerous specimens of Inoceramus have been collected from successive stratigraphic horizons, the variation is quantitatively investigated on the sample from each horizon, and the morphological relation between successive samples is examined.

It would be of course desirable to reexamine various species of Cretaceous Inoceramus from the population concept. The present work is, however, far from the requirements of the population paleontology in proper sense. First of all the so-called "fossil population" does not correspond with a populatin of a recent species. As will be mentioned in the next chapter, the examined specimens of a sample are in most cases probably autochthonous as judged from the mode of occurrence and as shown by a normal distribution in the frequency of selected characters. In such a case of fossil population could represent approximately a local breeding population. In some cases, however, specimens of two or more species may have been transported and embedded in the same place.

Secondly, a species of Inoceramus generally has a wide geographical distribution. Although it may form clusters at various places within its extensive biogeographical province, each sample in the present study was collected from a limited thickness of bed exposed narrowly at a restricted locality. The actual local breeding population must have had an areal distribution of a certain extent. In this respect the examined sample cannot be strictly regarded as representing the true population but it is only a fraction of the biological unit. I know that the most of the species dealt with in this paper are not confined to Southwest Japan but occur more abundantly in Hokkaido, Sakhalin and elsewhere.

Thirdly in the Onogawa and the Uwajima Group the Inoceramus bearing beds which contain abundantly well preserved specimens are allocated discontinuously in the sequence. Although I endeavoured to find fossiliferous beds as finely as possible, the two groups involve strata of flysch-type facies in which non- or poorly fossiliferous beds intervene frequently. Furthermore, a large number of specimens are necessary for the statistical examination. The samples from the fossili- 
ferous beds of the two groups are sometimes insufficient in number and preservation.

Lastly there are practically unavoidable differences in the strict interpretation between recent and fossil species. A recent species consists of synchronous populations and is recognized through anatomical morphology, heredity, breeding or reproduction, distribution and mode of life, whereas a fossil species consists of heterochronous populations and we are obliged to depend on the preserved morphological characters, the comparison of them between different stratigraphical levels and geographical provinces and also on some knowledge on the mode of life and distribution inferred from the occurrence.

Taking the above conditions into consideration, the present work is indeed preliminary. Yet the results would be worthy of description, since little attempt has hitherto been done for the statistical treatment of successive samples of Inoceramus. I hope this work would be a step towards more satisfactory work in the future.

Before going further, I thank Professor Tatsuro MATsumoto of Kyushu University for his cordial supervision and critical reading of the typescript; and also to Prof. Tsugio Shuto, Dr. Kametoshi Kanmera, Dr. Tomowo Ozawa, Dr. Hiromichi Hirano and Mr. Kazushige TANABE for their helpful advices and fruitful discussions. Further, I am indebted to Dr. Ikuwo OBATA of National Science Museum, Tokyo, Mr. Teruo SaTo of Chiba University and Mr. Tatsuo Muramoto for their help in the field work of the Futaba Group, and Mr. Shinichi SATo of Oita Educational Center and Mr. Kiyoshi KaI of Ogata-Town-Office, Ono County, Oita Pref., in the field work of the Onogawa Group, and also Messrs. Kuniaki MAKINo and Toshiomi HoRIKome in the Uwajima Group. My gratitude is due to following persons, Dr. Ikuwo OBata, Mr. Kazushige TaNaBe and Dr. Tatsuro MATSUMOTO for their kindness in supplying a large number of specimens for this study and Messrs. Hiroyuki Yamamoto, Shin Totoki, Osamu Mitsukude, Seiji KoHI, Seiichi Toshimitsu for their cooperation in collecting the specimens with me.

Their collections are indicated by the following abbreviations: GK. Geological Collections at Kyushu University, Fukuoka; JG. NoDA Coll., Oita; JM. MitsuKUdE Coll., Oita; MK. YamaMoto Coll., Oita; TO. TotoKI Coll., Oita.

This study has been completed in Kyushu University under the auspices of the Oita Educational Commission.

\section{Note on Stratigraphy}

For the examination of the chronological change of morphology in fossil species on the viewpoint of population, the following conditions are desirable: (1) The stratigraphic sequence should be exactly known as to fossiliferous beds from which the samples are obtained. (2) A large number of individuals can be obtained from a bed, and (3) The specimens are autochthonous and well-preserved, showing original characters. Actually, it is difficult to satisfy all conditions in a sequence of one geological province. In this study, following three sequences of somewhat separated areas (Fig. 1) are selected to complement the insufficient conditions with one another. They are (1) Tano Formation on the southeastern wing of the Onogawa basin, (2) the main part of the Onogawa Group on the western wing of 


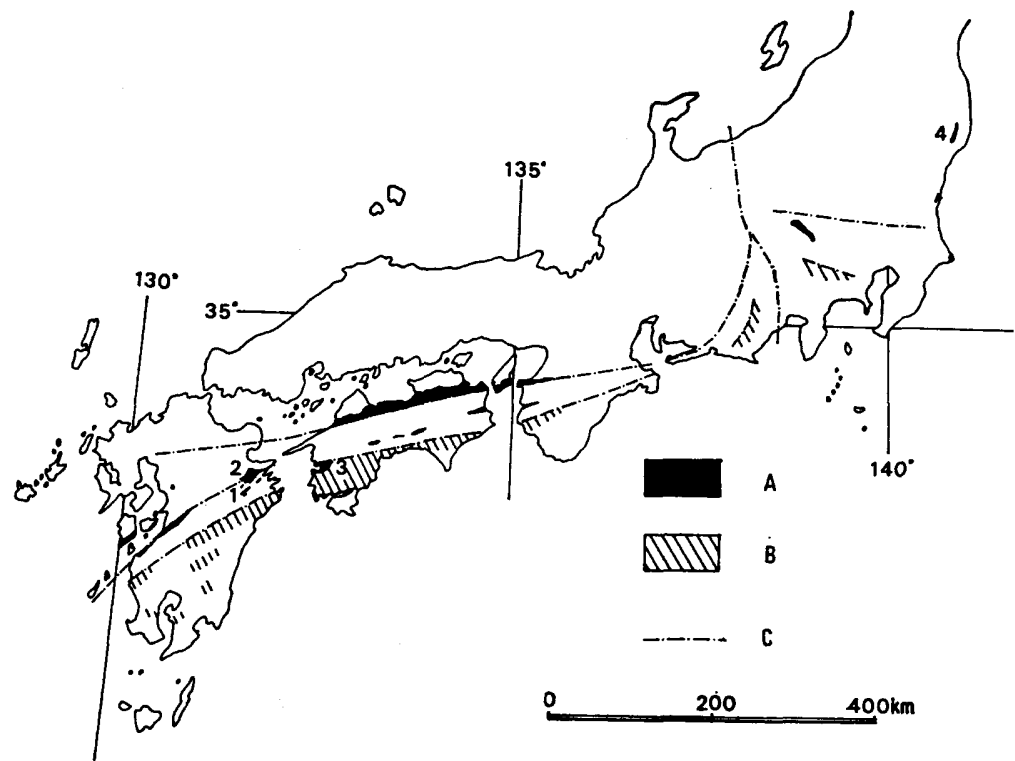

Fig. 1. Map showing the outcrop of the Cretaceous in Japan.

A: Cretaceous marine deposits. B: Probable Cretaceous marine deposits. C: Boundary of the geological provinces.

1: Tano Formation. 2: Main part of Onogawa Group. 3: Uwajima Group. 4: Futaba Group.

the same basin, and (3) the Uwajima Group.

Further, the Futaba Group in Northeast Japan is appended as a supplementary material. Before going into paleontological main part, I briefly give stratigraphic notes which are cited from NoDA (1969) and TANABE (1972).

\section{Upper Cretaceous of the Onogawa basin}

The Upper Cretaceous deposits called the Onogawa Group are developed in a basin-like area along the River Onogawa and its tributaries, central Kyushu. For details of the geology of this area see MATSumoto (1936), FUJII (1954), NodA (1969) and TERAOKA (1970).

\section{(1) Tano Formation}

This is included in the Onogawa Group, although it is separated at present by a fault from the main part on the southeastern side. The lithostratigraphic map is shown in Fig. 2. The formation is divided into three members: (a) Lower member is about $360 \mathrm{~m}$ in thickness, and unconformably oversteps the Lower Cretaceous Haidateyama Formation. It consists of ill-sorted conglomerate with an intercalation of black shale about $4 \mathrm{~m}$ in thickness. FuJII (1954) recorded the occurrence of Inoceramus concentricus nipponicus NAGAO et MATSUMOTO from the black shale. (b) Middle member is about $600 \mathrm{~m}$ in thickness and consists of medium-grained sandstone with frequent intercalations of thin-bedded black shale. (c) Upper member is about $1300 \mathrm{~m}$ in thickness and consists of well-bedded sandstone and shale with intercalations of a conglomerate and three layers of acid tuff. 


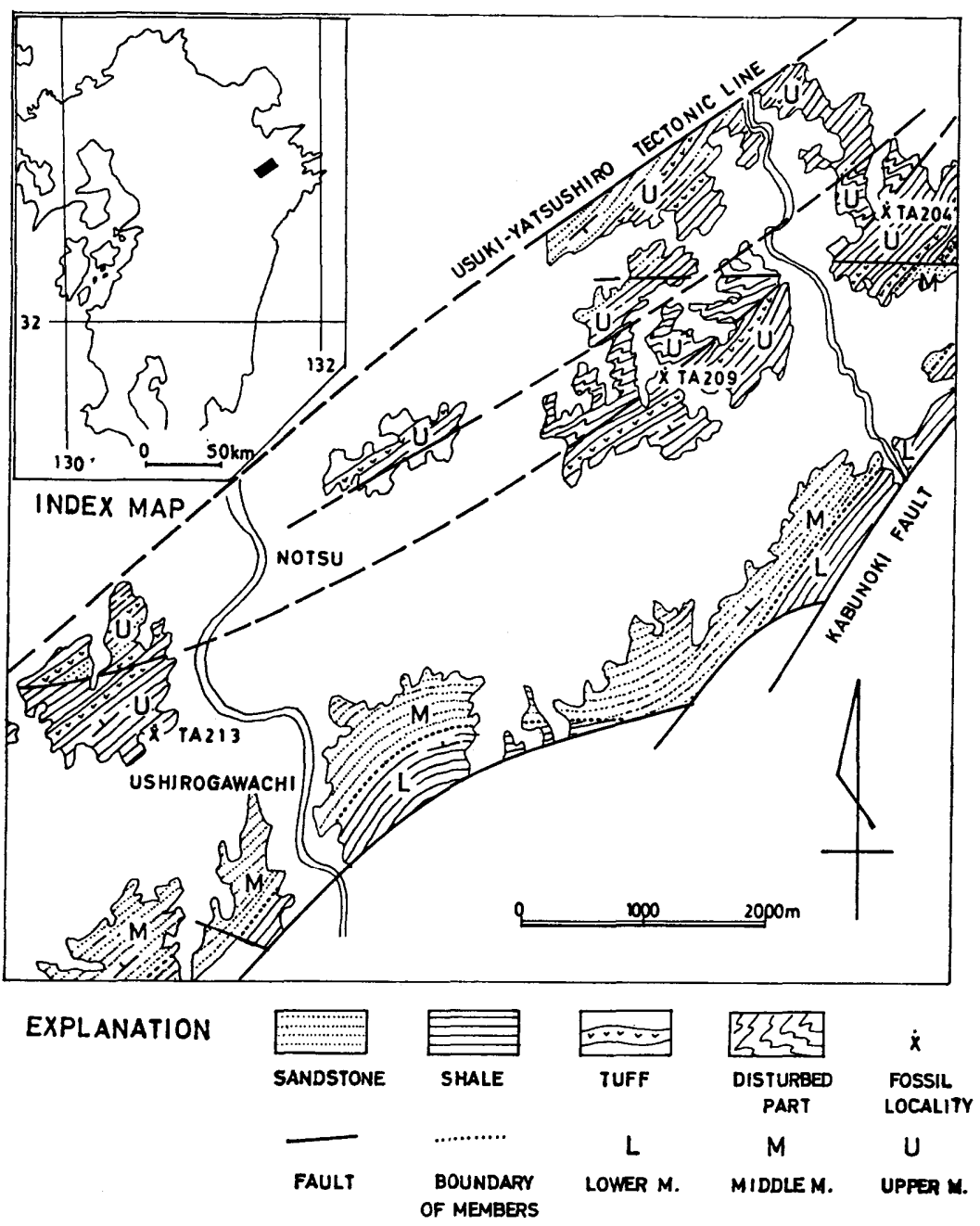

Fig. 2. Lithostratigraphic map of the Tano Formation in the Notsu area (Rocks other than the Tano Formation are left blank). (Adopted from TERAOKA, 1970)

Sample TA213 was obtained from the shaly part.

\section{(2) Main part of the Onogawa Group}

This is subdivided into three subgroups including eight formations (NoDA, 1969 , p. 4).

A. Lower Subgroup

(a) Ryozen Formation. This is about $3600 \mathrm{~m}$ in thickness, overlying unconformably the folded Paleozoic rocks. The Lower member consists of thick beds of ill-sorted conglomerate in lower part, with some interbeds of red sandstone and tuffaceous rock, and becomes gradually predominant in sandstone upward. The Upper member consists of mudstone and conformably overlies the Lower member with abrupt vertical lithologic change. It is about $300 \mathrm{~m}$ in thickness in a section 


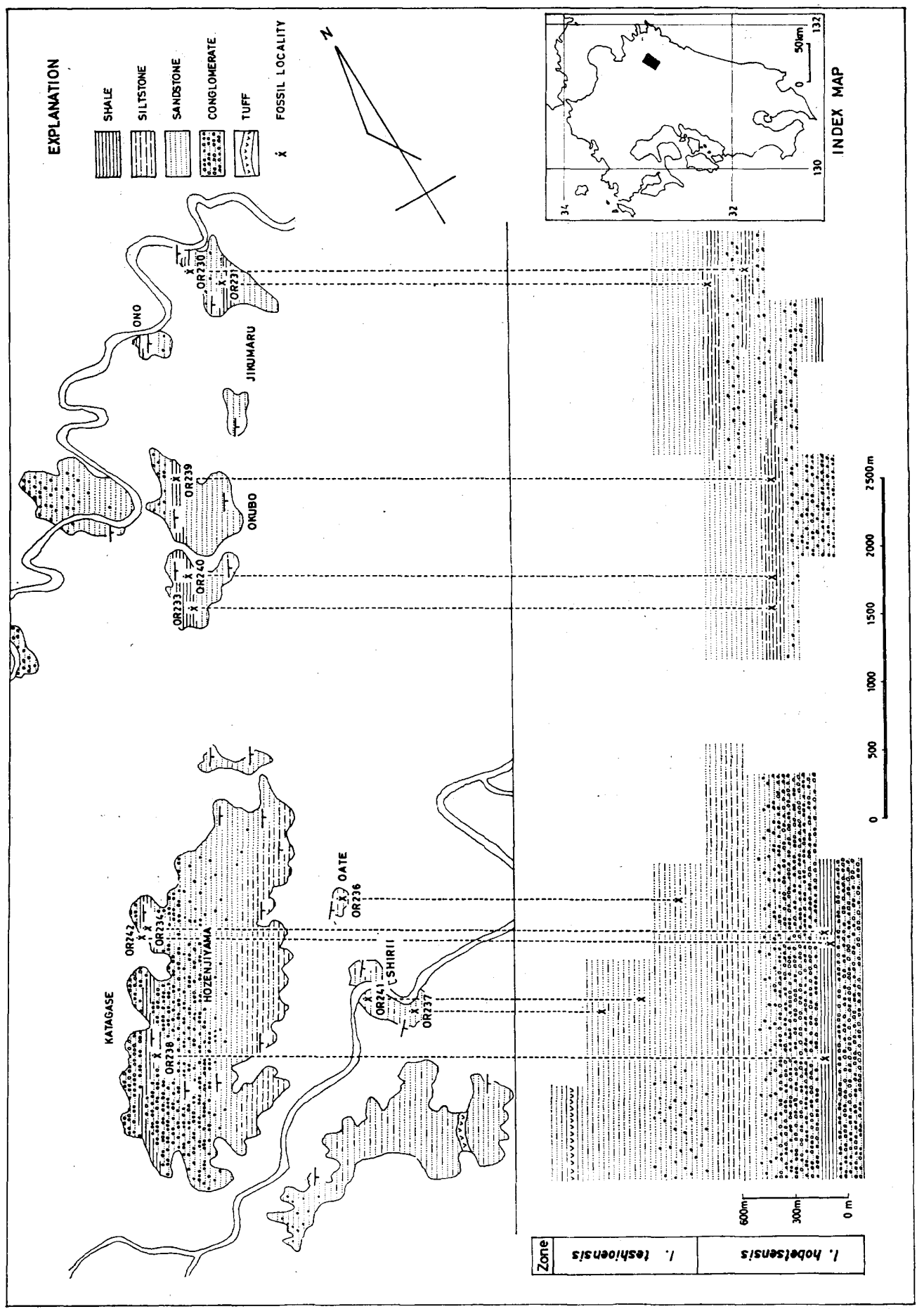

Fig. 3. Lithostratigraphic map and diagramatic profile of the Onogawa Group in the Taketa area. 
at Yudachi, about $12 \mathrm{~km}$ south from the center of Oita City, and gradually thickens southwestward, attaining $1300 \mathrm{~m}$ or more at Katagase near Taketa City, where sandstone and conglomerate are frequently inserted; thus the lateral change of lithofacies is remarkable. The distribution of the Upper member in the Taketa area and its facies change are shown in Fig. 3. Fossils are abundant at various horizons.

(b and c) Okugawarauchi and Nakagawarauchi Formations. The former conformably overlies the Upper member of the Ryozen Formation and is in turn overlain conformably by the latter. They consist of well-bedded pebble conglomerate and sandstone of various grades of coarseness, showing two major sedimentary cycles. Fossils are rare.

B. Middle Subgroup

(d) Shibakita Formation. This is apparently conformable with the Nakagawarauchi Formation, but a partial disconformity is presumed by a large amount of reworked rock fragments occurring at its basal part. Its main part consists of sandstone and shale in alternation.

(e) Inukai Formation. About $2500 \mathrm{~m}$ in thickness in a section at Takasu, about $12 \mathrm{~km}$ southeast from the center of Oita City. Lower member: sandstone and shale in alternation gradually become thin-bedded upward. Grading is common in sandstone. Fossils are rare. Upper member: alternation of thick-bedded sandstone and shale, sometimes with intercalations of pebble conglomerate, becoming gradually thin-bedded and with more predominant shale upward. A large number of specimens of Inoceramus occur in certain beds of this member. Samples OI213 and OI214 are obtained from these beds, of which Sample OI214 represents the uppermost horizon. The lithostratigraphic map of this formation in the Inukai area is shown in Fig. 4a. The lateral and vertical changes in lithofacies mean instability of sedimentary environment. The fossils are found in rocks of various grades of grain size but they are commonly autochthonous. This may imply that they were enbedded under various sedimentological environments.

The explanation of the sequence above the Inukai Formation is omitted, because it has no relation with the samples concerned with this study.

\section{Uwajima Group}

This Group is widely developed in the Uwajima area, western Shikoku, about $70 \mathrm{~km}$ southeast of the Onogawa basin, occupying the area of about $20 \mathrm{~km}$ from north to south and about $30 \mathrm{~km}$ from east to west. As to the stratigraphy, I rely upon TANABE (1972), who divided this group into three subgroups and eight formations.

A. Lower Subgroup

(a, b and c) Shitaba, Chiyoura and Iwainomori Formations. The details are omitted because of the no relation with the samples.

B. Middle Subgroup

(d) Narukawa Formation. About $1500 \mathrm{~m}$ in thickness in a section at Mutsuki. The lithostratigraphic map is shown in Fig. 4b. The Lower member overlies the Iwainomori Formation with a local disconformity; basal conglomerate is characterized by reworked blocks and fragments, gradually grading into well-bedded coarse sandstone, which, in turn, becoming finer upward. Sample UN101 was obtained from this member. The Upper member consists of compact mudstone, which is partly shaly. Fossils of numerous species occur abundantly at various 


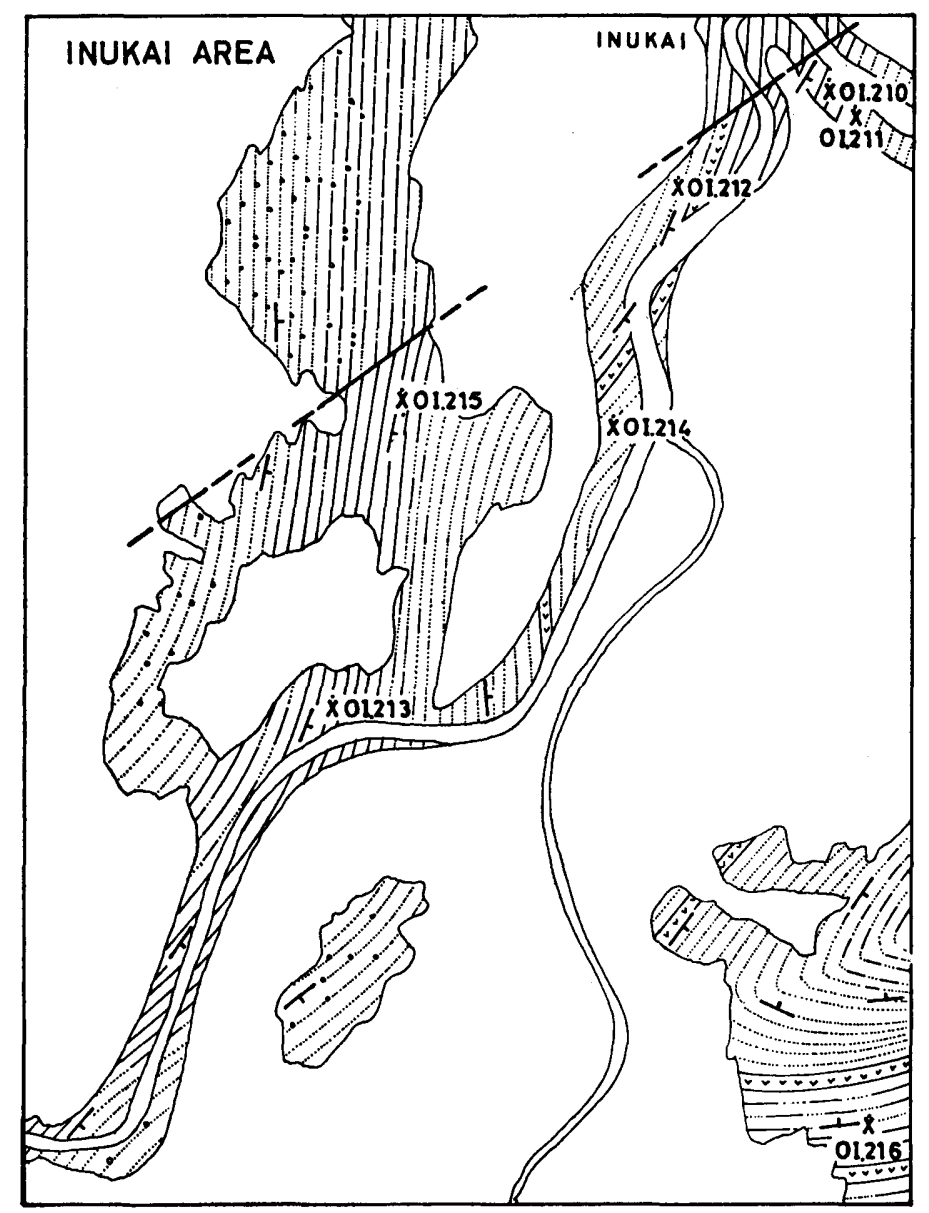

Fig. 4a. Lithostratigraphic map of the Inukai area.

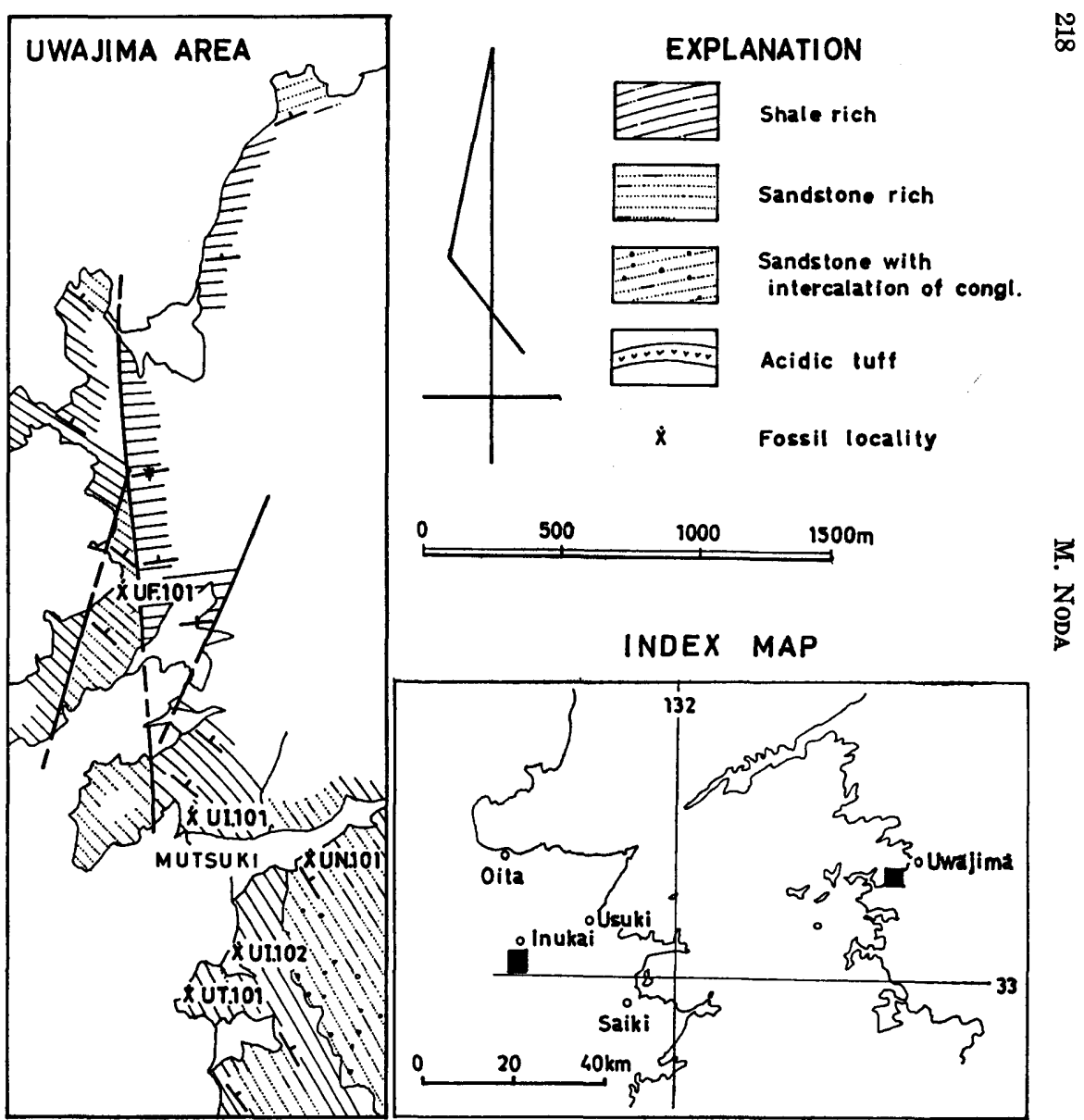

4b. Lithostratigraphic map of the Uwajima area. 
horizons.

(e and f) Ishibiki and Shimoyasuda Formations. The details are omitted because of no relation with the samples.

(g) Furushiroyama Formation. About $900 \mathrm{~m}$ in thickness. The stratigraphic allocation in the sequence is uncertain because of its separated distribution by faulting. The Lower member consists of shale and mudstone, with interbeds of acid tuff. The Middle member is medium-grained sandstone and the Upper member massive mudstone, partially with alternation of mudstone and sandstone, which shows grading. Fossils of numerous species occur abundantly at various horizons throughout the member. This member exposed in the Koike area is called the Koike mudstone (KUD0, 1949). Sample UF101 was obtained from the middle part of this mudstone.

(h) Makinoyama Formation. The details are omitted because of no relation with the sample.

\section{Correlation between the described sequences}

As mentioned in the section of the Ryozen Formation, the fossils from various horizons in the mudstone would provide suitable samples to examine the chronological change of species. Samples OR242, OR234, OR233 and OR218 from the Upper member of the Ryozen Formation satisfy such examination. Three species of Subprionocyclus, S. neptuni (GEINTZ), S. bravaisianus (D'ORBIGNY) and $S$. normalis (ANDERSON), occur in ascending order in the Upper member of the Ryozen Formation. They indicate the upper part of the Middle Turonian, the lower part of the Upper Turonian and somewhat below the top of the Upper Turonian respectively (MATSUMOTO, 1969).

The Upper member of the Tano Formation is approximately correlated to a part of the Upper member of the Ryozen Formation by means of Suprionocyclus neptuni. The associated species of Inoceramus closely resembles a broad form of Inoceramus labiatus from Hokkaido, which is found at lower horizons than that of Inoceramus hobetsensis (MATSUMOTO and OKADA, 1973; MATSUMOTO and NoDA, 1975). The Upper member of the Tano Formation, therefore, may include slightly earlier part than the $S$. neptuni zone of the Ryozen Formation. Sample TA213 represents the available lowest horizon of the Turonian of this region.

The fossils from the Shibakita Formation and the Lower member of the Inukai Formation are not sufficiently numerous for statistic treatment. To obtain supplementary information, the equivalent formations to the Shibakita and the Inukai Formations are examined in the Uwajima Group.

According to the resemblance in sedimentary facies and faunal assemblage, the Shibakita and Inukai Formations of the Onogawa Group could be probably correlated to the Narukawa and Furushiroyama Formations of the Uwajima Group respectively.

TANABE ascribed the sequence from the Narukawa to Furushiroyama Formations to the age ranging from the lower part of the Lower Urakawan (Coniacian) to the lower part of the Upper Urakaran (Santonian) by means of inocerami, in accordance to MATSUMOTO's scheme of the biostratigraphic correlation.

According to personal information from OBATA and MATSUMoto, Forresteria sp., a useful index of the Coniacian, came from the Furushiroyama Formation, at Hode (U49 of TANABE, 1972). 


\section{Futaba Group}

The Futaba Group is exposed in the area along the Pacific Coast of Fukushima Prefecture. It is divided into three formations (SAITO, 1962).

(a) Lower Formation. Lower part: basal conglomerate rests nonconformably on granite. Upper part: siltstone and shale. Fossiliferous beds occur at two horizons. The lower bed is characterized by the poorly preserved heterogenous shells showing an allochthonous assemblage and the Upper bed is probably autochthonous. Sample AS201 was obtained from the upper one.

( $b$ and $c$ ) Middle and Upper Formations. The details are omitted because of no relation with the samples.

The age of this group was regarded as Coniacian. OвAтA (1967) and ОвAтA and SUZUKI (1969), however, pointed out that it ranges up to lower Santonian on the evidence of new acquisitions. According to personal information from MATSUмото and Овата, Forresteria sp. (identified by Matsumoto) occurs in the Lower Formation.

\section{Material}

The samples examined in the present study are mainly collected from the Onogawa Group, because its stratigraphic sequence is precisely known. Two samples from the Uwajima Group are supplied for the shortage in a part of the Onogawa sequence. Furthermore, a sample from the Futaba Group is added for comparison.

Samples OR242 and UN101 are evidently autochthonous, because the specimens are of commonly closed valves and buried vertically to bedding planes with their anterior end downward. Sometimes the umbo and the anterior part are pushed into an underlying sandstone bed, while the main part of the shell is contained within the mudstone above the sandstone.

The specimens of other samples are probably allochthonous, but the distance between their habitat and place of burial is presumed to have been short, because they are preserved as articulated valves or little damaged and because it is unreasonable to consider that huge individuals more than $200 \mathrm{~mm}$ in shell height were transported for a great distance from the habitat to the embedding where clay and silt were deposited.

In spite of a great number of specimens from each locality, the available ones for measurements are only 20-30 percent of them. Others are insufficiently preserved, i.e. partly deficient or secondarily deformed. The sample size for the selected characters are shown in Table 1.

Sample Guide

Sample TA213 Locality: Inukai Quad. (1:50000); Onogawa basin of central Kyushu. Long. $131^{\circ} 41^{\prime 22} 2^{\prime \prime} \mathrm{E}$, Lat. $33^{\circ} 01^{\prime} 39^{\prime \prime} \mathrm{N}$. An eastern foot of hill about $500 \mathrm{~m}$ eastward from Ushirogawachi, Notsu Town, Ono County, Oita Pref. Str. position: Upper member of Tano Formation. Mode of occurrence: Common in black shale about $60 \mathrm{~cm}$ in thickness; commonly inarticulated valves disposed parallel to bedding plane and crushed; together with Nanonavis sachalinensis (SCHMIDT), Propeamussium cowperi yubarensis (YABE et Nagao), Acila sp., Lucina sp., Yoldia sp. cf. Y. hobetsensis (NAGao et Otatsume), Scalarites sp. and Subprionocyclus neptuni (GEINTZ).

Sample OR242 Locality: Taketa Quad. (1:50000), Onogawa basin of central Kyushu. Long. $131^{\circ} 25^{\prime} 17^{\prime \prime} \mathrm{E}$, Lat. $32^{\circ} 57^{\prime} 05^{\prime \prime} \mathrm{N}$. A waterway side of Katagase, about $50 \mathrm{~m}$ west of 
Table 1. Sample size for selected characters.

\begin{tabular}{|c|c|c|c|c|c|c|c|c|c|c|}
\hline \multicolumn{2}{|c|}{$\begin{array}{l}\text { character } \\
\text { Sample }\end{array}$} & \multicolumn{2}{|c|}{$\mathrm{L} / \mathrm{H}$} & \multicolumn{2}{|c|}{$\beta$} & \multirow{2}{*}{$\begin{array}{c}\begin{array}{c}\text { rejection } \\
\text { ellipse }\end{array} \\
37\end{array}$} & \multicolumn{2}{|c|}{$\begin{array}{l}\text { relative } \\
\text { growth }\end{array}$} & \multirow{2}{*}{$\begin{array}{c}\begin{array}{c}\text { rib } \\
\text { density }\end{array} \\
12\end{array}$} & \multirow{2}{*}{\begin{tabular}{|c|c|c|}
$\begin{array}{c}\text { total } \\
\text { number }\end{array}$ \\
65
\end{tabular}} \\
\hline TA 213 & $\begin{array}{l}\mathrm{A} \\
\mathrm{B}\end{array}$ & 38 & $\begin{array}{l}17 \\
21\end{array}$ & 41 & $\begin{array}{l}17 \\
24\end{array}$ & & 39 & $\begin{array}{l}17 \\
22\end{array}$ & & \\
\hline \multicolumn{2}{|c|}{ OR 242} & \multicolumn{2}{|c|}{35} & \multicolumn{2}{|c|}{37} & 34 & \multicolumn{2}{|c|}{16} & 8 & 47 \\
\hline \multicolumn{2}{|c|}{ OR 234} & \multicolumn{2}{|c|}{27} & \multicolumn{2}{|c|}{32} & 27 & \multicolumn{2}{|c|}{23} & 11 & 130 \\
\hline \multicolumn{2}{|c|}{ OR 233} & \multicolumn{2}{|c|}{30} & \multicolumn{2}{|c|}{30} & 29 & \multicolumn{2}{|c|}{33} & 19 & 164 \\
\hline \multicolumn{2}{|c|}{ OR 218} & \multicolumn{2}{|c|}{13} & \multicolumn{2}{|c|}{13} & 13 & \multicolumn{2}{|c|}{28} & 8 & 87 \\
\hline UN 101 & $\begin{array}{l}\text { A } \\
\text { B }\end{array}$ & 42 & $\begin{array}{l}31 \\
11\end{array}$ & 41 & $\begin{array}{l}30 \\
11\end{array}$ & 41 & 55 & $\begin{array}{l}37 \\
18\end{array}$ & 8 & 68 \\
\hline \multicolumn{2}{|l|}{ UF 101} & \multicolumn{2}{|c|}{41} & \multicolumn{2}{|c|}{42} & 41 & \multicolumn{2}{|c|}{41} & 9 & 52 \\
\hline \multicolumn{2}{|l|}{ OI 213} & \multicolumn{2}{|c|}{61} & \multicolumn{2}{|c|}{55} & 55 & \multicolumn{2}{|c|}{72} & 8 & 139 \\
\hline OI 214 & $\begin{array}{l}\mathbf{A} \\
\mathbf{B}\end{array}$ & 46 & $\begin{array}{l}25 \\
21\end{array}$ & 44 & $\begin{array}{l}28 \\
16\end{array}$ & 44 & 63 & $\begin{array}{l}37 \\
26\end{array}$ & 4 & 105 \\
\hline \multicolumn{2}{|l|}{ AS 201} & \multicolumn{2}{|c|}{45} & \multicolumn{2}{|c|}{45} & 45 & \multicolumn{2}{|c|}{51} & 11 & 85 \\
\hline
\end{tabular}

OR234, Ogata Town, Ono County, Oita Pref. Str. position: Lower part of Upper member of Ryozen Formation, Onogawa Group. Mode of occurrence: Fairly abundant in black shale; commonly closed valves which are vertical to bedding plane; sometimes secondarily deformed postero-anteriorly; associated with Mesopuzosia pacifica MATSUмото and Hemiaster sp.

Sample OR234 Locality: Taketa Quad. (1:50000); Onogawa basin of central Kyushu. Long. $131^{\circ} 25^{\prime} 16^{\prime \prime} \mathrm{E}$, Lat. $32^{\circ} 51^{\prime} 05^{\prime \prime} \mathrm{N}$. A quarry at the northern foot of Mt. Hozenjiyama, near the waterway of Katagase, Ogata Town, Ono County, Oita Pref. Str. position: Lower part of Upper member of Ryozen Formation, Onogawa Group, about $40 \mathrm{~m}$ above the horizon of OR242. Mode of occurrence: Common in black shale; commonly separated valves disposed parallel to bedding plane; fairly well-preserved; mostly moderate in size but sometimes more than $200 \mathrm{~mm}$ in $\mathrm{H}$; associated with Nanonavis sachalinensis (Shmidt), Portlandia sp., Pinna sp., Crenella sp., Gyrodes sp., Subprionocyclus neptuni (Geintz), Yubariceras sp. cf. Y. yubarense Matsumoto, SaIto et Fukuda, Mesopuzosia pacifica MATSUmoto and Hemiaster sp.

Sample OR233 Loiality: Takeda Quad. (1:50000); Onogawa basin of central Kyushu. Long. $131^{\circ} 26^{\prime} 02^{\prime \prime} E$, Lat. $32^{\circ} 58^{\prime} 02^{\prime \prime} \mathrm{N}$. A quarry of Sumiyaki, Ogata Town, Ono County, Oita Pref. (see Fig.). Str. position: Lower part of Upper member of Ryozen Formation, Onogawa Group, about $300 \mathrm{~m}$ above the horizon of OR234. Mode of occurrence: Common in siltstone, inarticulated or closed valves which are parallel to bedding plane; frequently huge individuals more than $400 \mathrm{~mm}$ in $\mathrm{H}$ and sometimes $800 \mathrm{~mm}$ in $\mathrm{H}$; generally well-preserved; rarely associated with Propeamussium cowperi yubarensis (YABE et NAGAo), Nanonavis sachalinensis (SchmidT), Acila sp., Lucina sp., Mesopuzosia pacifica MATSUMOTo, M. indopacifica Kossmat, Yubariceras sp. cf. Y. yubarense Matsumoto, SaIto et FukUda and Otoscaphites sp.

Sample OR218 Locality: Inukai Quad. (1:50000); Onogawa basin of central Kyushu. Long. $131^{\circ} 32^{\prime} 56^{\prime \prime} \mathrm{E}$, Lat. $33^{\circ} 05^{\prime} 11^{\prime \prime} \mathrm{N}$. A cliff of the backyard of Nakahaji-Post-Office, Ono Town, Ono County, Oita Pref. Str. position: Middle part of Upper member of Ryozen Formation, Onogawa Group, probably more than $1300 \mathrm{~m}$ upward of OR234 in the sequence. Mode of occurrence: Crowded in black shale; commonly closed valves and 


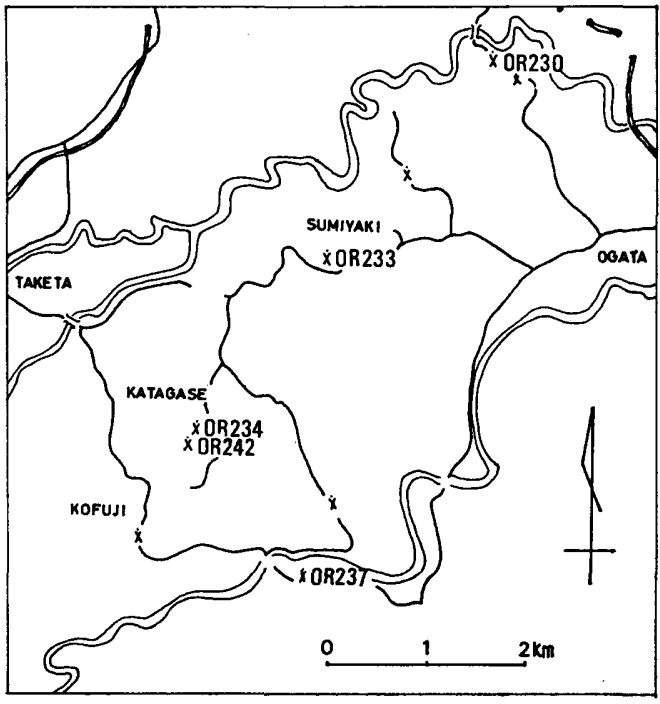

Fig. 5. Locality map of the Onogawa Group in the Taketa area. disposed parallel to bedding plane but some verical; mostly crushed laterally, but few individuals ventro-dorsally; associated with Propeamussium cowperi yubarensis (YABE et NAGAO), Lucina sp., Nanonavis sp., Subprionocyclus bravaisianus (D'ORBIGNY), Scalarites sp. cf. S. scalaris (Y $\mathrm{ABE}$ ), Hyphantoceras sp. and Hemiaster sp. Sample UN101 Locality: Uwajima Quad. (1:50000); western coast of Shikoku. Long. $132^{\circ} 31^{\prime} 08^{\prime \prime} \mathrm{E}$, Lat. $33^{\circ} 11^{\prime} 08^{\prime \prime}$ N. A cliff on road side from Mutsuki to Ishibiki, about $500 \mathrm{~m}$ away from Mutsuki, Uwajima City, Ehime Pref. (see Fig. 6). Str. position: Lower part of Narukawa Formation, Uwajima Group, about $70 \mathrm{~m}$ above the disconformity plane at the base of this formation. Mode of occurrence: Very crowded at the boundary of underlying sandstone and overlying mudstone; closed valves, some of them are ver-

tical to the bedding plane being anterior end downward, and well-preserved keeping original shell characters; no other species associated with the sample.

Sample UF101 Locality: Uwajima Quad. (1:50000) ; western coast of Shikoku. Long. $132^{\circ} 30^{\prime} 25^{\prime \prime} \mathrm{E}$, Lat. $33^{\circ} 11^{\prime} 35^{\prime \prime} \mathrm{N}$. A southern beach of Koike-Primary-School, Uwajima City, Ehime Pref. Str. position: Upper part of Middle member of Furushiroyama Formation, Uwajima Group. Mode of occurrence: Common in siltstone and fine-grained sandstone; valves inarticulated, parallel to bedding plane and well-preserved, together with Anagaudryceras limatum (YABE), Gaudryceras tenuiliratum YABE, Scaphites yokoyamai JIMBo, Otoscaphites teshioensis (YABE), O. puerculus (JIMBo) and Didymotis akamatsui (YEHARA).

Sample O1213 Locality: Inukai Quad. (1:50000); Onogawa basin of central Kyushu. Long. $131^{\circ} 37^{\prime} 43^{\prime \prime} \mathrm{E}$, Lat. $33^{\circ} 02^{\prime} 14^{\prime \prime} \mathrm{N}$. A cliff on road side from Hosonagabashi bridge to Shibayama, about $300 \mathrm{~m}$ westward from the rail-road crossing, Chitose Village, Ono County, Oita Pref. (see Fig. 7). Str. position: Lower part of Upper member of Inukai Formation, Onogawa Group. The sample is obtained from the upper one of the two fossiliferous beds. Mode of occurrence: Common in calcareous black shale; low articulation ratio, well-preserved, commonly parallel to bedding plane, and not together with any other species.

Sample 0I214 Locality: Inukai Quad. (1:50000); Onogawa basin of central Kyushu. Long. $1^{\circ} 37^{\prime}$ $40^{\prime \prime} \mathrm{E}$, Lat. $33^{\circ} 02^{\prime} 16^{\prime \prime} \mathrm{N}$. A right

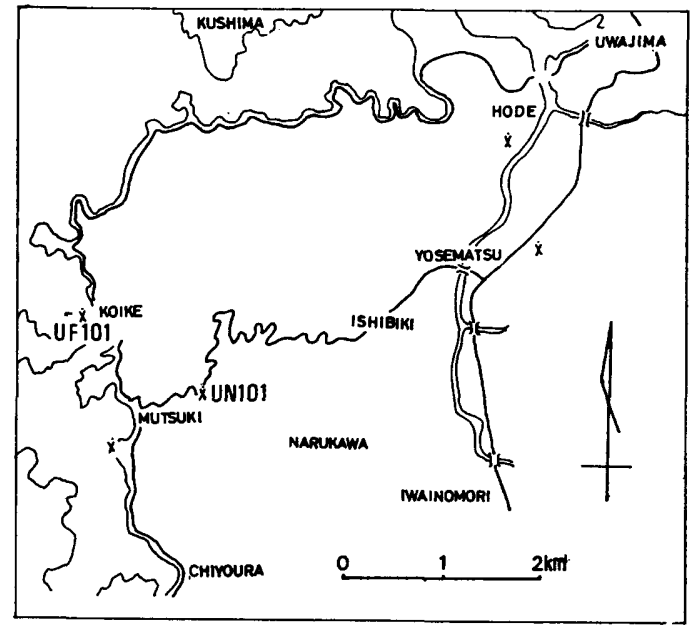

Fig. 6. Locality map of the Uwajima Group. 
bank of Onogawa about $50 \mathrm{~m}$ downstream of the confluence of the tributary "Miegawa", Sugao Village, Ono County, Oita Pref. Str. position: Upper part of Upper member of Inukai Formation, Onogawa Group, about $500 \mathrm{~m}$ above the horizon of OI213. Mode of occurrence: Crowded in sandstone of about $45 \mathrm{~cm}$ in thickness, closed or open and separated valves; well preserved; not together with any other species.

Sample AS201 Locality: Kawamae Quad. (1:50000); Pacific coast of Fukushima Pref. Long. $140^{\circ} 56^{\prime} 51^{\prime \prime}$, Lat. $37^{\circ} 10^{\prime} 20^{\prime \prime}$ N. A road cutting from Yachi to Ashizawa, Ohisa Town, Iwaki City, Fukushima Pref. Str. position: Upper part of Lower Formation, Futaba Group. Mode of occurrence: Abundant in siltstone of about $2 \mathrm{~m}$ in thickness; closed or separate valves, fairly well-preserved with original shell characters, mostly parallel to bedding plane.

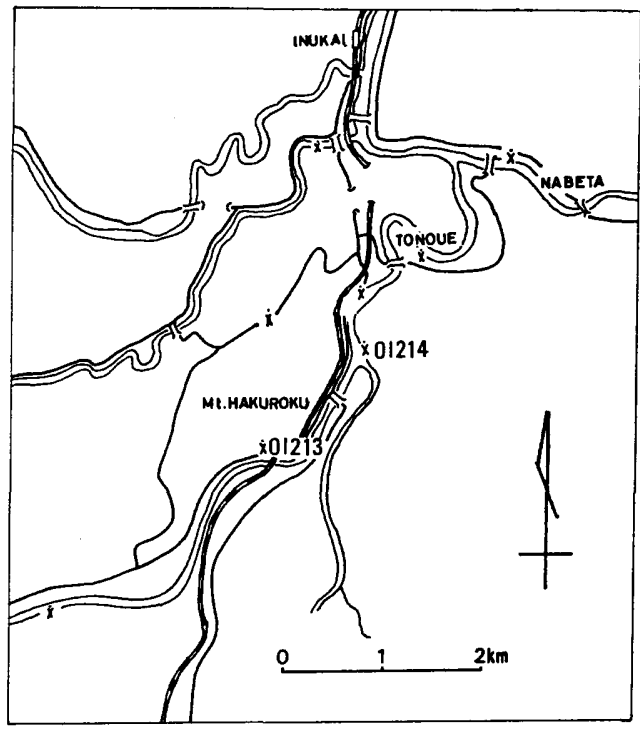

Fig. 7. Locality map of the Onogawa Group in the Inukai area.

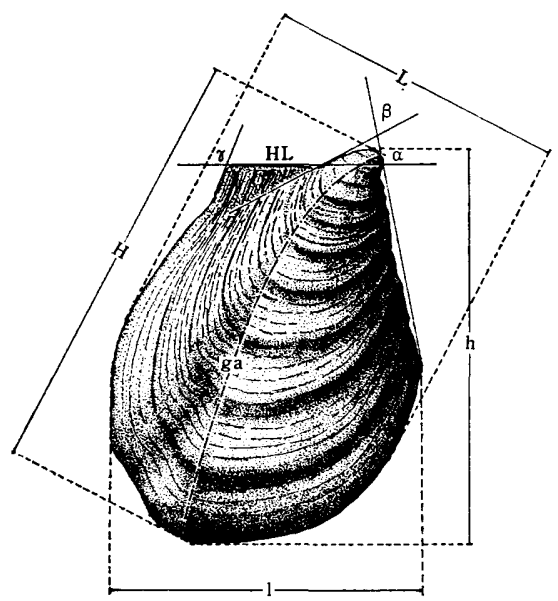

Fig. 8. Basic morphology and measurements.

\section{Method of Analysis}

In this paper the following characters are statistically examined (see Fig. 8). (1) Simple ratio of $\mathrm{L}$ to $\mathrm{H}$ ( $\mathrm{H}$ : dimension from umbo to ventral extremity, $\mathrm{L}$ : maximum dimension of the line perpendicular to $\mathrm{H}$ )

(2) Beak angle $(\beta)$ : angle of umbonal inflation

(3) Correlation between tangent $\beta / 2$ and simple ratio $\mathrm{L} / \mathrm{H}$

(4) Rib density between $30 \mathrm{~mm}$ and $60 \mathrm{~mm}$ in $\mathrm{H}$

(5) Pattern of average relative growth of $\mathrm{L}$ with $\mathrm{H}$

(6) Surface ornamentation

(7) Presence or absence of anterior and posterior wing-like areas which are examined by observation.

A calipers of JIS standard, $20 \mathrm{~mm}$ in measurable range and $1 / 20 \mathrm{~mm}$ in accuracy, and a contact goniometer are used for measurements of length and angle respectively. Measurement was done for three times for the same part and the mean value is shown. The basic analyses are carried on by the following process. 
Table 2. $F$-test and STUdent's $t$-test for simple ratio $\mathrm{L} / \mathrm{H}$ between right and left valves.

\begin{tabular}{|c|c|c|c|c|c|c|c|c|c|c|}
\hline \multicolumn{2}{|c|}{ Sample } & $\mathbf{N}$ & $\mathbf{M}$ & $s$ & $\mathrm{n}$ & $F$ & $F_{0.05}$ & $t$ & $t_{0.05}$ & significancy \\
\hline \multirow{2}{*}{ OR242 } & LV & 7 & 0.75 & 0.05 & \multirow{2}{*}{9} & \multirow{2}{*}{1.000} & \multirow{2}{*}{4.120} & \multirow{2}{*}{0.319} & \multirow{2}{*}{2.262} & \multirow{2}{*}{ not sig. } \\
\hline & RV & 4 & 0.76 & 0.05 & & & & & & \\
\hline \multirow{2}{*}{ OR234 } & LV & 6 & 0.75 & 0.05 & \multirow{2}{*}{24} & \multirow{2}{*}{1.440} & \multirow{2}{*}{4.568} & \multirow{2}{*}{0.741} & \multirow{2}{*}{2.064} & \multirow{2}{*}{ not sig. } \\
\hline & RV & 20 & 0.77 & 0.06 & & & & & & \\
\hline \multirow{2}{*}{ OR233 } & LV & 11 & 0.76 & 0.08 & \multirow{2}{*}{28} & \multirow{2}{*}{1.266} & \multirow{2}{*}{2.789} & \multirow{2}{*}{1.524} & \multirow{2}{*}{2.048} & \multirow{2}{*}{ not sig. } \\
\hline & RV & 19 & 0.81 & 0.09 & & & & & & \\
\hline
\end{tabular}

Table 3. $F$-test and STUDENT's $t$-test for beak angle between right and left valves.

\begin{tabular}{|c|c|c|c|c|c|c|c|c|c|c|}
\hline \multicolumn{2}{|c|}{ Sample } & $\mathrm{N}$ & $\mathbf{M}$ & $s$ & $\mathbf{n}$ & $F$ & $F_{0.05}$ & $t$ & $t_{0.03}$ & significancy \\
\hline \multirow{2}{*}{ OR242 } & LV & 15 & 68 & 4 & \multirow{2}{*}{23} & \multirow{2}{*}{1.563} & \multirow{2}{*}{2.645} & \multirow{2}{*}{0.554} & \multirow{2}{*}{2.069} & \multirow{2}{*}{ not sig. } \\
\hline & RV & 10 & 67 & 5 & & & & & & \\
\hline \multirow{2}{*}{ OR234 } & LV & 6 & 76 & 4 & \multirow{2}{*}{20} & \multirow{2}{*}{1.563} & \multirow{2}{*}{4.619} & \multirow{2}{*}{1.752} & \multirow{2}{*}{2.086} & \multirow{2}{*}{ not sig. } \\
\hline & $\mathrm{RV}$ & 16 & 72 & 5 & & & & & & \\
\hline \multirow{2}{*}{ OR233 } & LV & 11 & 74 & 6 & \multirow{2}{*}{27} & \multirow{2}{*}{1.440} & \multirow{2}{*}{2.450} & \multirow{2}{*}{0.969} & \multirow{2}{*}{2.052} & \multirow{2}{*}{ not sig. } \\
\hline & RV & 18 & 76 & 5 & & & & & & \\
\hline
\end{tabular}

$\mathrm{N}$ : sample size

$\mathrm{M}$ : mean

$s:$ standard deviation

$\mathrm{n}$ : degree of fredom in STUDENT' $t$-test

$F_{0.05}: 5$ perceht significant limit in $F$-test

$t_{0.05}: 5$ percent significant limit in STUDENT's $t$-tset
LV: left valve

RV: right valve

1. Evaluation of the significancy for difference in both valves-Owing to insufficient number of specimens, I have examined the adequacy to take the statistics on left and right valves altogether in term of the simple ratio $\mathrm{L} / \mathrm{H}$ and the beak angle, because the shell is inequivalve in the Turonian species.

In order to evaluate the significancy of standard deviation between a pair of samples, I have tried $F$-test. Based on the result of the $F$-test, the STUDENT's $t$-test is attempted. The method and the calculation are omitted. (see TANABE, 1973).

The results of the STUDENT's $t$-test are shown in Tables 2 and 3. They indicate the adequacy to take the statistics regardless of right or left valves.

2. Evaluation of normal distribution.-At first, the frequency distribution is shown in histogram, the abscissa being divided into $1 / 2$ power of the sample size. Then, the chi-square test is used for the evaluation of the null hypothesis of normal distribution in selected characters i.e. simple $\mathrm{L} / \mathrm{H}$, beak angle and rib density. 
If the result of the chi-square test is significant, the null hypothesis for the sample is rejected and the sample is reexamined as a composite of samples from two or more populations.

3. Evaluation of the difference of the mean of scelected characters.On the samples of which chi-square value is insignificant, the significance differences in the selected characters are evaluated between the samples by the STUdenT's $t$-test. And then, the chronological change of the simple ratio $\mathrm{L} / \mathrm{H}$ and that of the beak angle are examined by means of the frequency distribution separated by common units.

4. Examination by the method of the rejection ellipse. - On the two variables at a growth stage of $40 \mathrm{~mm}$ in $\mathrm{H}$, plotting the tangent of $\beta / 2$ in ordinate and the simple ratio $\mathrm{L} / \mathrm{H}$ in
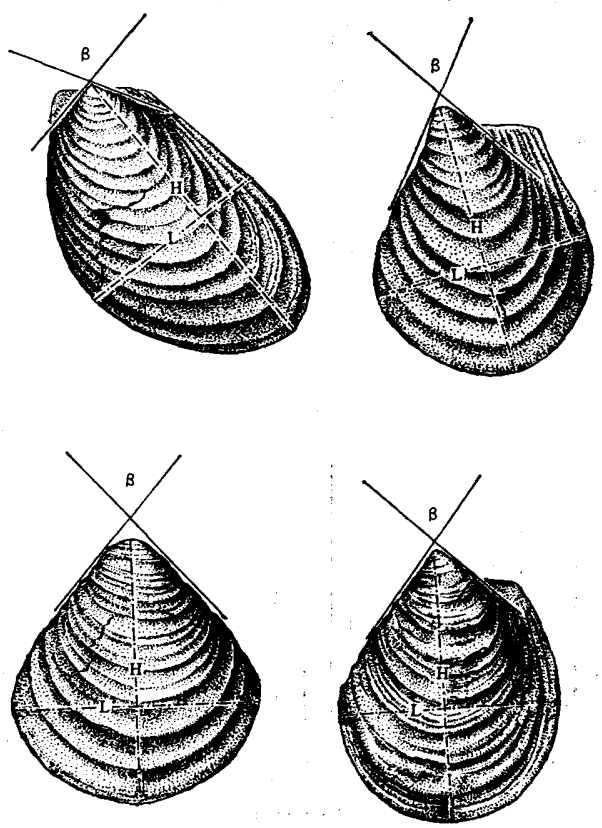

Fig. 9. Relation between the simple ratio $\mathrm{L} / \mathrm{H}$ and beak angle. abscissa, a method of the rejection ellipse is attempted. As the necessary conditions to apply the rejection ellipse, two variables must be independent on each other and show a normal distribution and the coefficient of correlation between the variables must not be great. In general, the simple ratio $\mathrm{L} / \mathrm{H}$ is closely related to the beak angle in most bivalves, but the selected characters show less correlation in inoceramid species as shown in Fig. 9.

The rejection ellipse, generally, encircles the scattered points at the 95 percent confidence level, but in the present paper, it is expressed at the confidence of 68 percent level, which expresses more directly the density of the distribution. The data of the rejection ellipse are calculated by means of degital computer and a set mathematical equation. Then the chronological change of characters encircled in rejection ellipse is examined.

5. Examination of average relative growth.-The two variables, $\mathrm{L}$ and $\mathrm{H}$, are concerned with examination, plotting $\mathrm{H}$ in ordinate and $\mathrm{L}$ in abscissa on logarithmic graph paper, and the striking feature of the reduced major axis is calculated. Then the chronological change of growth ratio $(a)$ and that of initial growth indices $(b)$ are examined respectively.

6. Examination of surface ornamentation.-At first, the rib density between $30 \mathrm{~mm}$ and $60 \mathrm{~mm}$ in $\mathrm{H}$ is numerically examined because there are some individuals whose concentric ribs are hardly discernible in early stage of growth. The results of the statistical examination are compared with each other as cases in simple ratio $\mathrm{L} / \mathrm{H}$ and beak angle. Then, the total numbers of concentric rib are counted at the growth stages graduated in $50 \mathrm{~mm}$ increments. This examination, however, is applied only huge individuals of Samples OR234 and OR233.

Finally, other characters of surface ornamentation, such as the presence or 

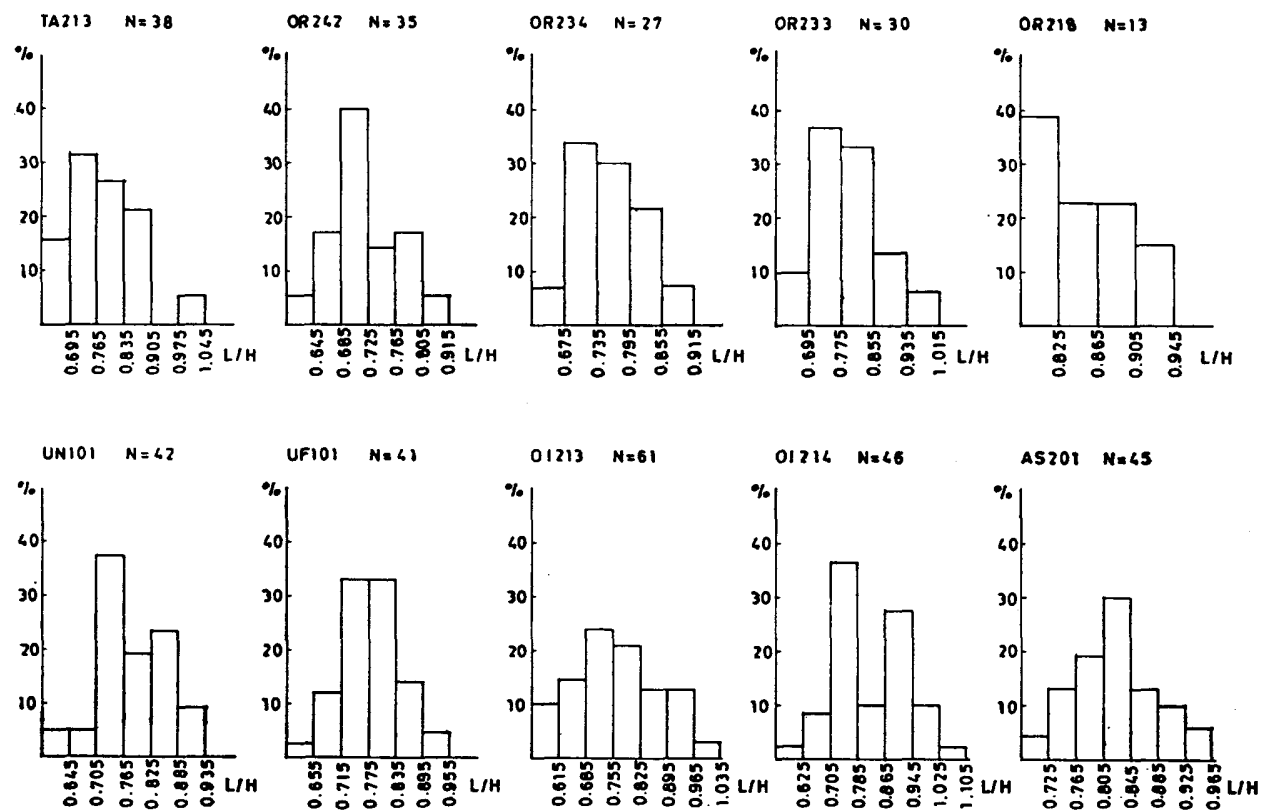

Fig. 10. Histogram showing the frequency of the simple ratio $L / H$ in each of the examined samples.
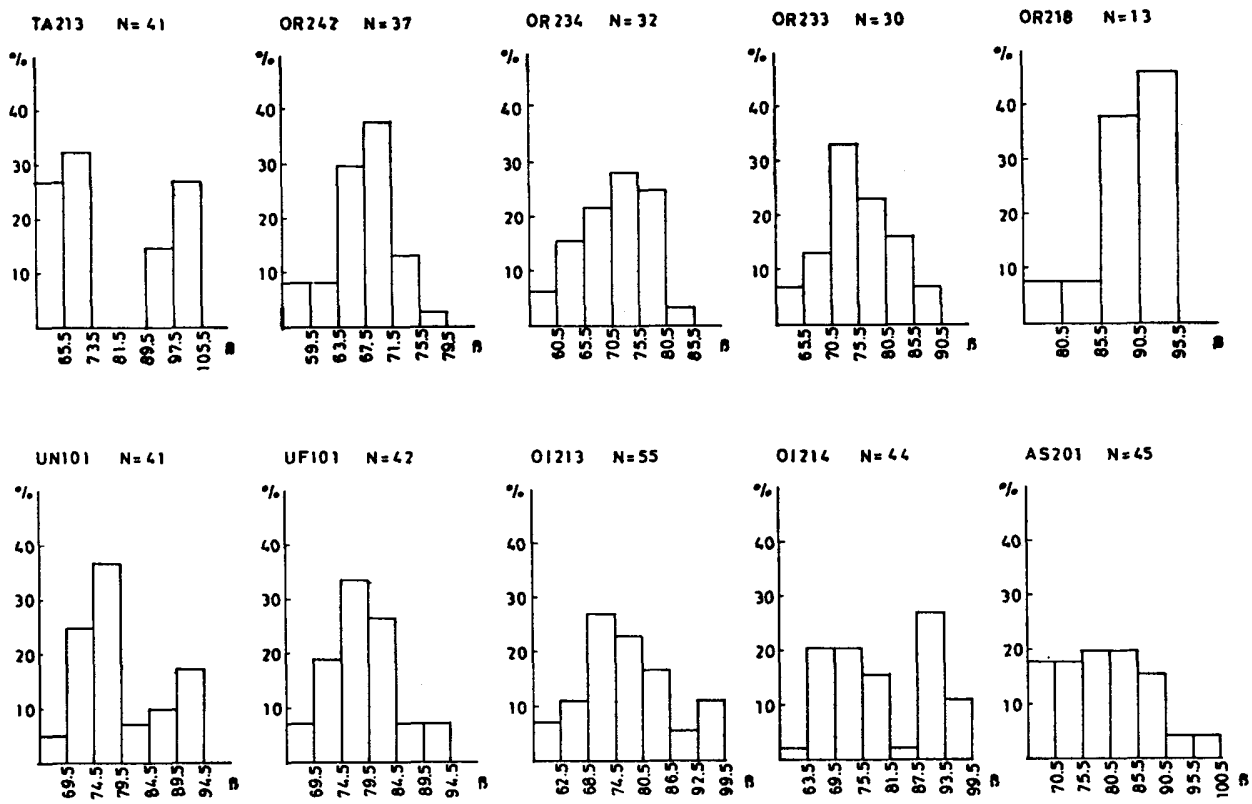

Fig. 11. Histogram showing the frequency of the beak angle in each of the examined samples.

absence of minor rings in the interspaces of major ribs, a radial depression from the umbo to the ventral extremity and the nodulous protuberances on either side of the radial depression, are examined. They are, however, unsuitable characters 

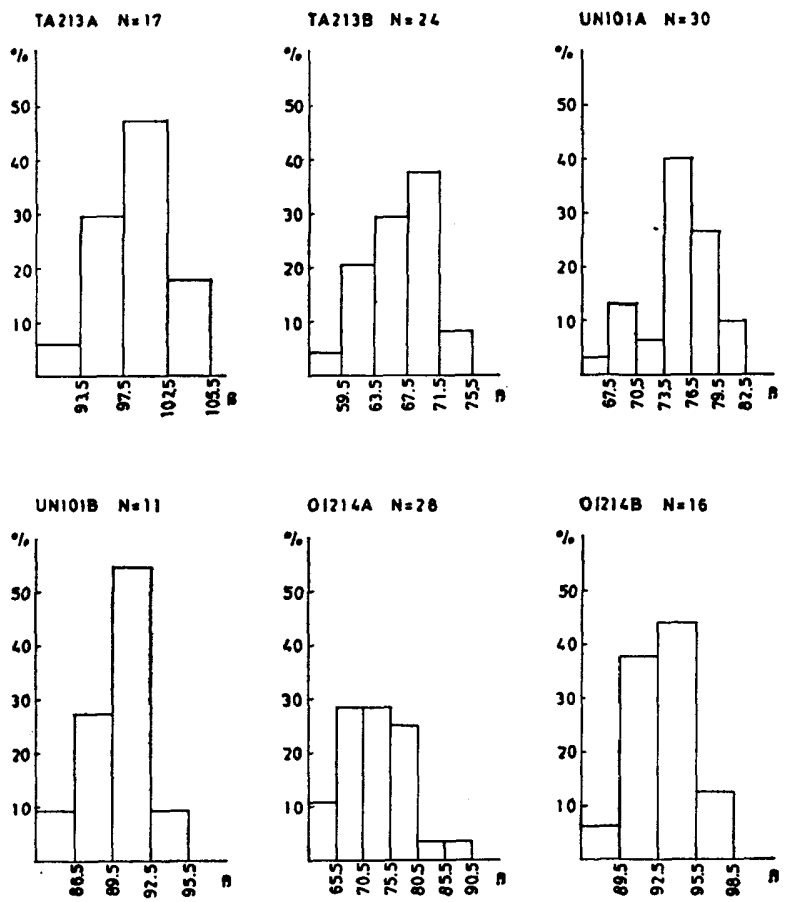

Fig. 12. Histogram showing the frequence of the beak angle in the samples of Table 4c.

for the numerical treatment by the method of mensuration.

7. Application of the taxonomic criteria of infraspecific category.-I attempt to examine the results of above analyses in terms of the taxonomic criteria of infraspecific category. The $\mathbf{7 5}$ percent rule for the numerically mensurated characters and the short-cut method for the non-numerical ones are applied for this purpose.

\section{Results of Analyses}

1. Evaluation of the normal distribution in simple ratio $L / H$ and beak angle. -The frequency distribution of the simple ratio $\mathrm{L} / \mathrm{H}$ is shown in Fig. 10 and also that of the beak angle in Fig. 11. The latter shows the bimodal distribution in Samples TA213, UN101 and OI214. The hypothesis of normal distribution of the selected characters is examined by means of chi-square test and the results are shown in Table 4. Examining the simple ratio $\mathrm{L} / \mathrm{H}$, the chi-square value $X^{2}$ is not significant at 95 percent level on all the samples, as shown in Table $4 \mathrm{~A}$. On the other hand, the chi-square value $X^{2}$ of the beak angle, as shown in Table $4 B$, indicates that the hypothesis of the normal distribution is rejected in Sample TA213, UN101 and OI214. This fact suggests that these samples are heterogeneity of species or polymorphic phenotypes.

Accordingly they are respectively subdivided into two samples which, in turn, are examined again concerning the normal distribution. However, it is too difficult to subdivide the Samples UN101 and OI214 only by beak angle, because there are intermediate forms at the minimum of bimodal distribution. The samples are divided after consideration of another character, i.e. presence of minor rings. 
Table 4. Chi-square test for selected characters.

A. simple ratio $\mathrm{L} / \mathrm{H}$

\begin{tabular}{|l|c|c|c|r|c|}
\hline Sample & $\mathrm{N}$ & mean & $s$ & $\mathrm{~V}$ & $X^{2}$ \\
\hline TA213 & 38 & 0.78 & 0.09 & 11.54 & 2.39 \\
OR242 & 35 & 0.72 & 0.05 & 6.94 & 6.85 \\
OR234 & 27 & 0.76 & 0.06 & 7.89 & 3.44 \\
OR233 & 30 & 0.79 & 0.09 & 11.39 & 4.15 \\
OR218 & 13 & 0.86 & 0.05 & 5.81 & 1.54 \\
UN101 & 42 & 0.78 & 0.08 & 10.25 & 2.49 \\
UF101 & 41 & 0.78 & 0.07 & 8.97 & 2.79 \\
OI213 & 61 & 0.77 & 0.11 & 14.29 & 3.29 \\
OI214 & 46 & 0.82 & 0.11 & 13.41 & 1.98 \\
AS201 & 45 & 0.82 & 0.07 & 8.54 & 2.52 \\
\hline
\end{tabular}

B. beak angle

\begin{tabular}{|l|r|r|r|r|r|}
\hline TA213 & 41 & 80 & 17 & 21.25 & 14.62 \\
OR242 & 37 & 68 & 4 & 5.88 & 7.78 \\
OR234 & 32 & 71 & 6 & 8.54 & 4.84 \\
OR233 & 30 & 75 & 6 & 8.00 & 1.95 \\
OR218 & 13 & 89 & 5 & 5.62 & 4.71 \\
UN101 & 41 & 79 & 7 & 8.86 & 10.20 \\
UF101 & 42 & 78 & 6 & 7.69 & 2.17 \\
OI213 & 55 & 77 & 10 & 12.99 & 4.42 \\
OI214 & 44 & 80 & 11 & 13.75 & 7.88 \\
AS201 & 45 & 80 & 9 & 11.25 & 4.66 \\
\hline
\end{tabular}

C. beak angle on the significant samples in B

\begin{tabular}{|c|c|c|c|c|c|c|}
\hline \multirow{2}{*}{ TA213 } & A & 17 & 99 & 3 & 3.03 & 1.64 \\
& B & 24 & 66 & 4 & 6.06 & 2.01 \\
\hline \multirow{2}{*}{ UN101 } & A & 30 & 75 & 4 & 5.33 & 4.01 \\
& B & 11 & 90 & 2 & 2.22 & 7.29 \\
\hline \multirow{2}{*}{ OI214 } & A & 28 & 73 & 7 & 9.59 & 4.33 \\
& B & 16 & 92 & 2 & 2.13 & 3.37 \\
\hline
\end{tabular}

V: PEARSON's coefficient of variation

$X^{2}:$ chi-squear value

They are respectively subdivided into two populations, that is, TA213A, TA213B, UN101A, UN101B, OI214A and OI214B. The results of the chi-square test for the subdivided samples are all not significant as shown in Table 4C.

2. Chronological change.-The chronological change of the frequency distribution of the simple ratio $\mathrm{L} / \mathrm{H}$ is shown in Fig. 13. Samples OR242, OR234 and OR233 become gradually larger in the mean value and standard deviation. In other words, Sample OR242 occupies the left area of the abscissa in frequency distribution, showing the presence of many elongate forms along the growth axis. 


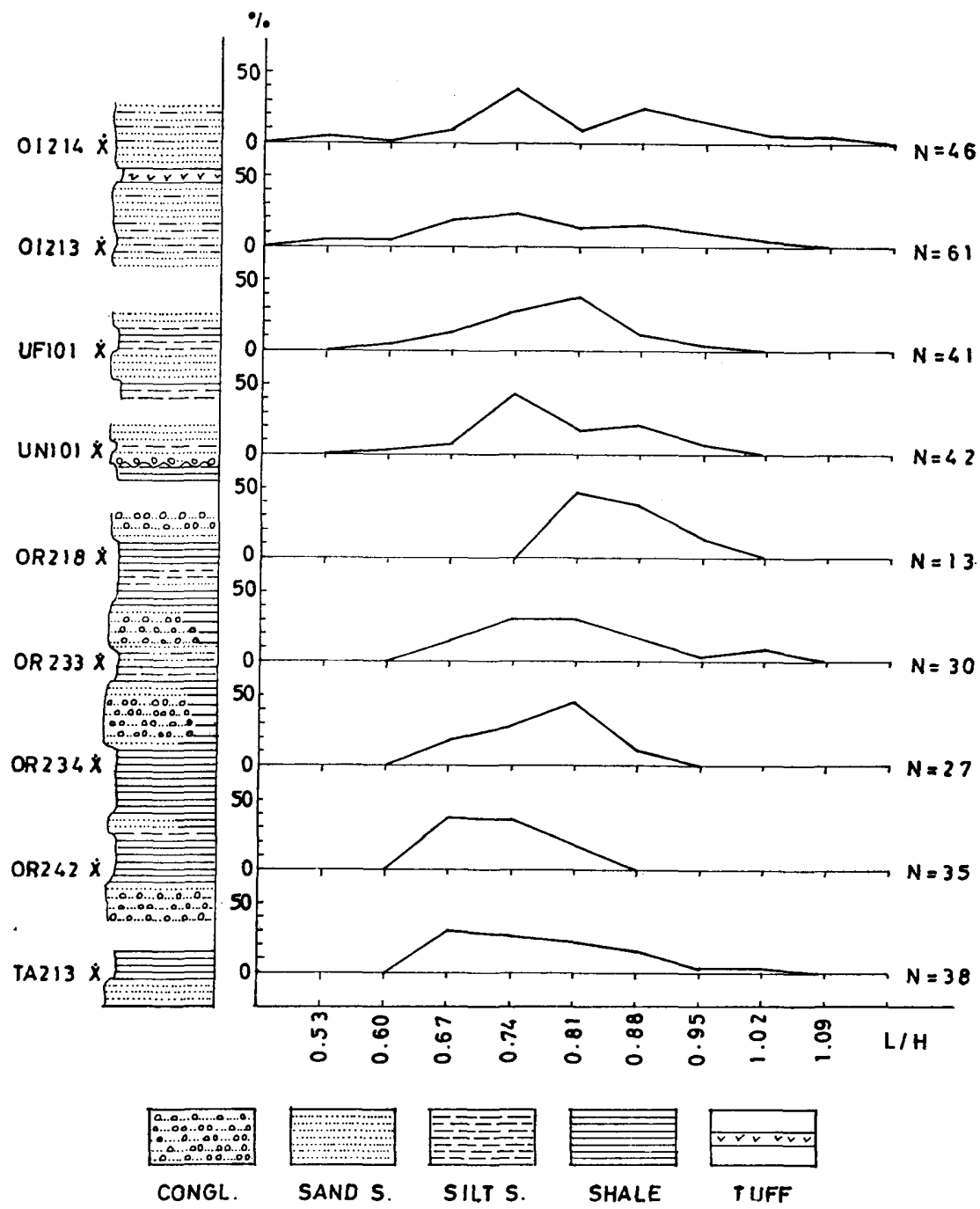

Fig. 13. Frequency distribution of the simple ratio $\mathrm{L} / \mathrm{H}$ in each of the stratigraphically successive sample.

Samples OR234 and OR233 show more extensive variation, and the broad form gradually increases in number as the sequence goes upward. Sample OR218 shows less extensive variation and the larger mean value than the above three samples. The change of the mean value between Samples OR233 and OR218 is abrupt or rather discontinuous. In the samples from the horizons higher than UN101, the frequency distribution shows very extensive variation which indicates the presence of various forms in outline.

The chronological change of frequency distribution of beak angle is shown in Fig. 14. As is evident from Fig. 14, in Samples TA213, UN101 and OI214 the frequency distribution of histogram shows the bimodal distribution which suggests the heterogeneity of species. The group representing the right area in the graph, TA213A, shows a peculiar form as shown in Fig. 15A. It probably belongs 


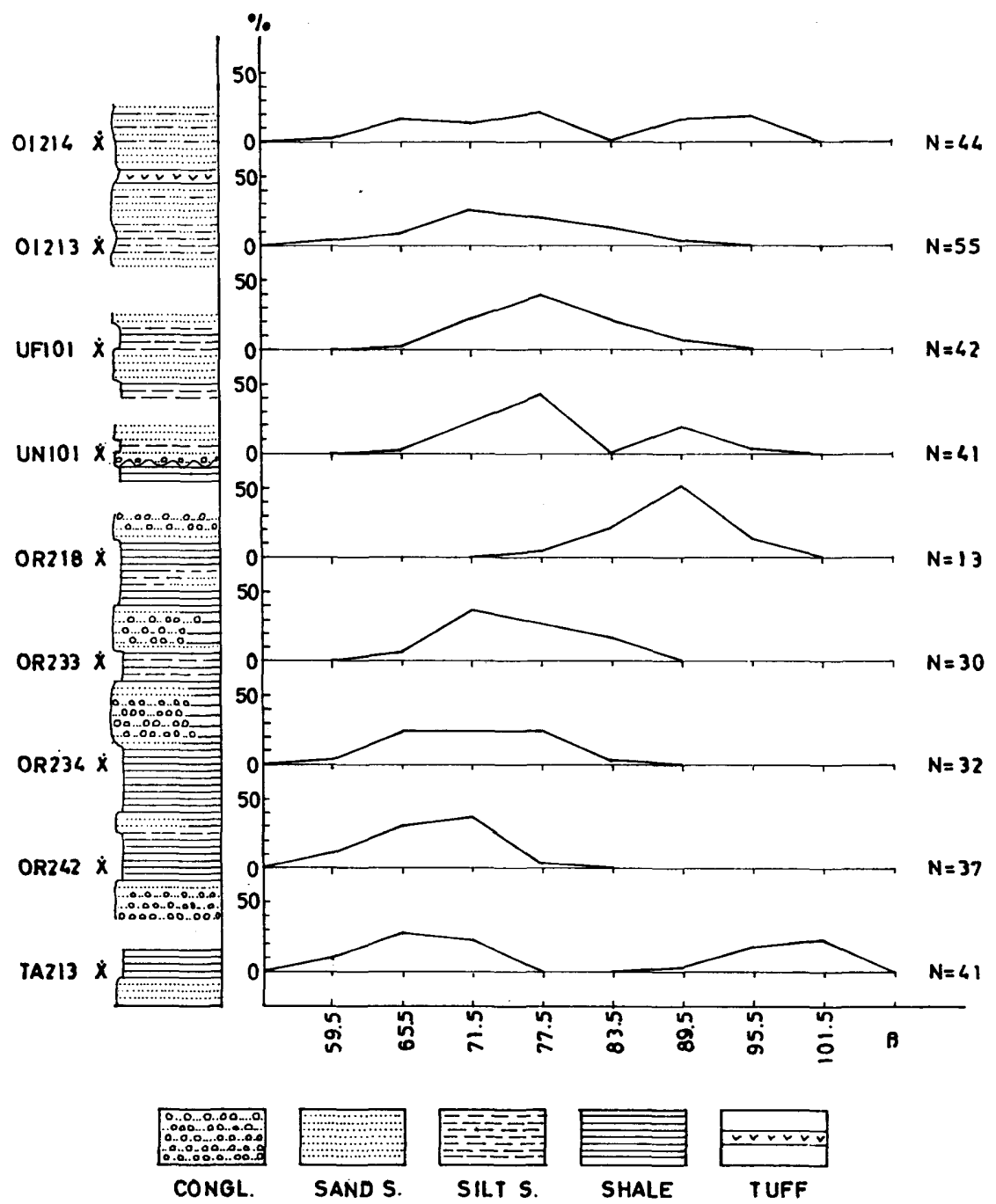

Fig. 14. Frequency distribution of the beak angle in each of the stratigraphically successive samples.

A

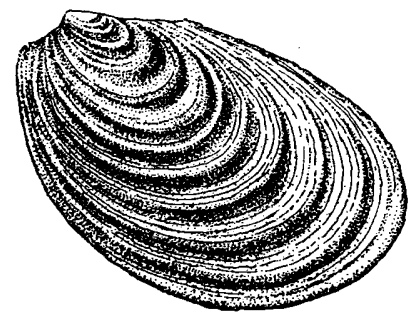

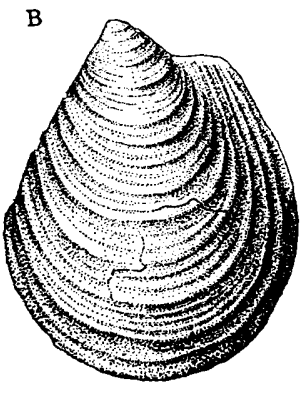

Fig. 15. A: Form of Sample TA213 A (Inoceramus teraokai).

B: Form of Samples OR218 and UN101B (Inoceramus teshioensis). 


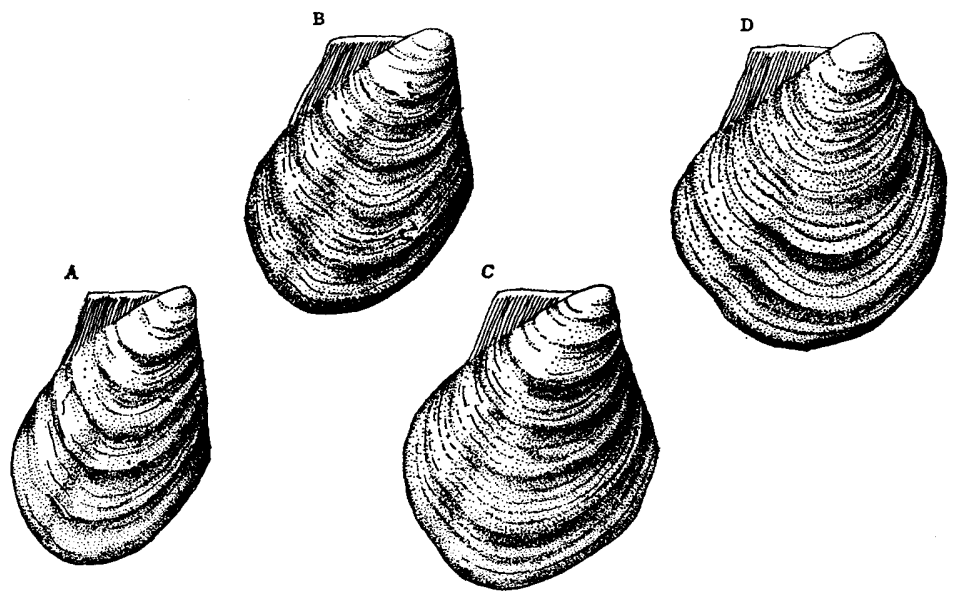

Fig. 16. Chronological change of outline in the Middle Turonian Inoceramus hobetsensis. Sample TA213B: A and B, Sample OR242: A and B, Sample OR234: B and C, Sample OR233: C and $D$

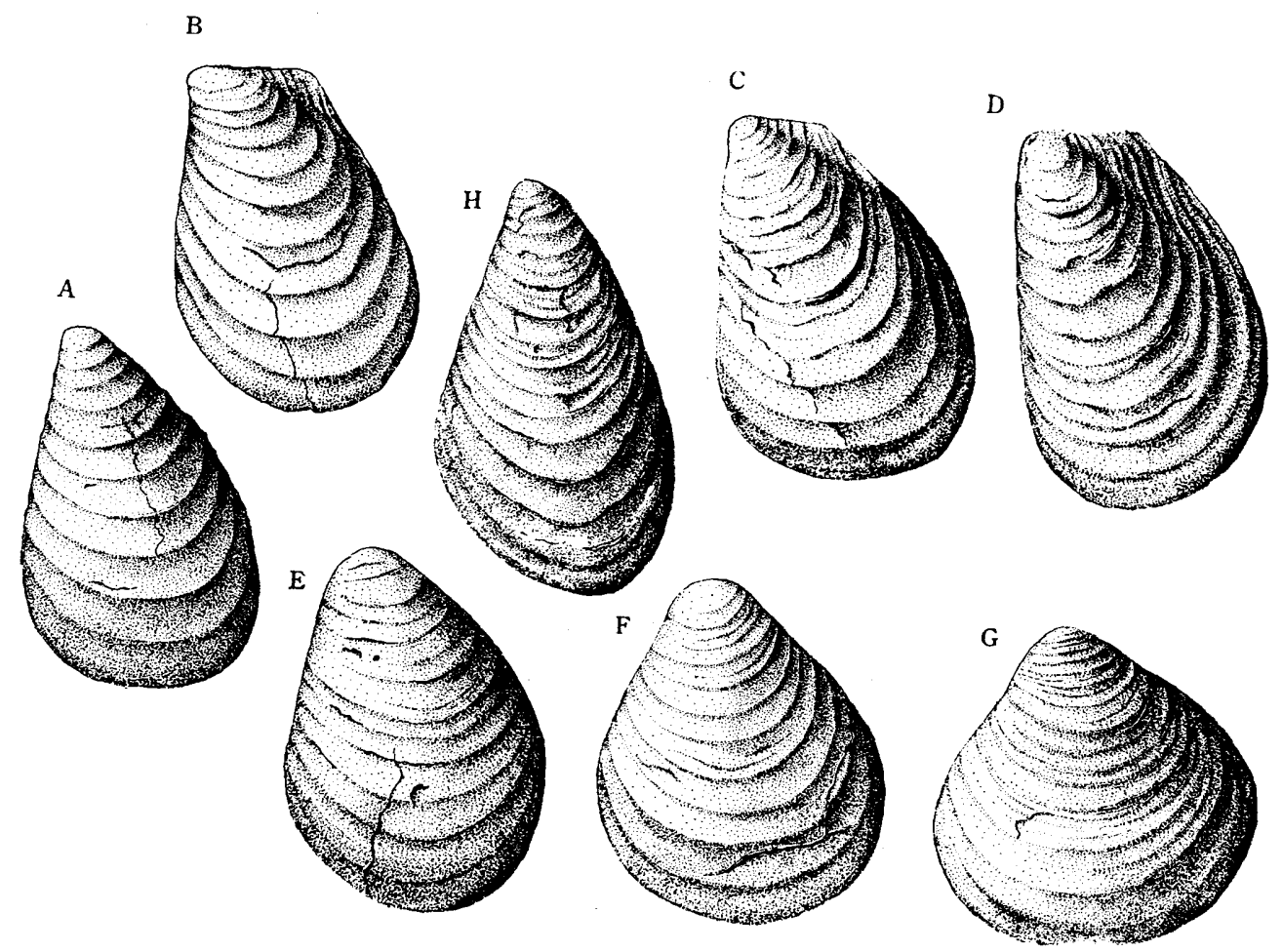

Fig. 17. Variation of outline in the Lower Coniacian Inoceramus uwajimensis. Sample UN101A: A, B and F. Sample UF101: A, B and F, Sample OI213: all forms, Sample OI214: A, B, C, D and G, Sample AS201: A, B, $\mathrm{D}, \mathrm{F}$ and $\mathrm{G}$ 

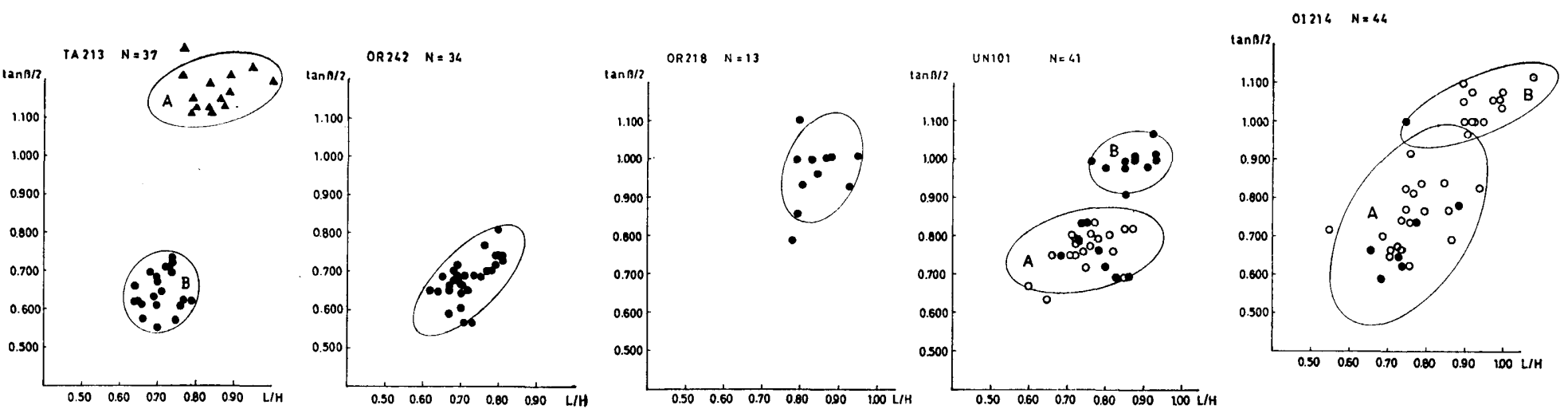

OR 234 $N=27$
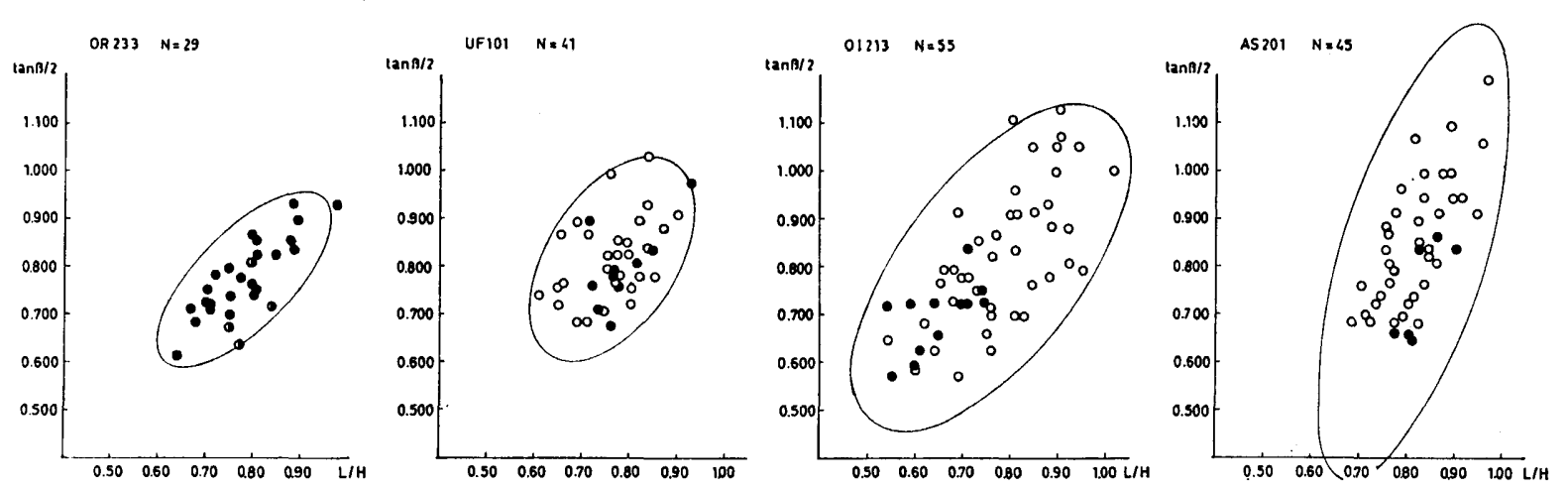

Fig. 18. Rejection ellipses showing at 68 percent confidence level. $\Delta$ : form with anterior wing wing $O$ : form without posterior wing $O$ : nodulous form 
Table 5. Date of rejection ellipse.

\begin{tabular}{|c|c|c|c|c|c|}
\hline Sample & $\mathrm{X}$ & $\mathrm{Y}$ & $\theta$ & $\lambda a$ & $\lambda b$ \\
\hline TA213A & 0.86 & 1.170 & $13^{\circ} 44^{\prime}$ & 0.35 & 0.16 \\
\hline TA213B & 0.71 & 0.652 & $59^{\circ} 15^{\prime}$ & 0.19 & 0.18 \\
\hline OR242 & 0.72 & 0.676 & $44^{\circ} 08^{\prime}$ & 0.35 & 0.15 \\
\hline OR234 & 0.76 & 0.719 & $58^{\circ} 17^{\prime}$ & 0.62 & 0.21 \\
\hline OR233 & 0.78 & 0.775 & $46^{\circ} 23^{\prime}$ & 0.48 & 0.81 \\
\hline OR218 & 0.86 & 0.980 & $67^{\circ} 01^{\prime}$ & 0.27 & 0.15 \\
\hline UN01A & 0.75 & 0.767 & $13^{\circ} 38^{\prime}$ & 0.38 & 0.20 \\
\hline UN101B & 0.87 & 0.997 & $14^{\circ} 02^{\prime}$ & 0.18 & 0.12 \\
\hline UF101 & 0.77 & 0.815 & $56^{\circ} 21^{\prime}$ & 0.46 & 0.26 \\
\hline OI213 & 0.77 & 0.802 & $52^{\circ} 04^{\prime}$ & 0.81 & 0.39 \\
\hline OI214A & 0.76 & 0.741 & $61^{\circ} 05^{\prime}$ & 0.61 & 0.27 \\
\hline OI214B & 0.94 & 1.042 & $25^{\circ} 25^{\prime}$ & 0.44 & 0.15 \\
\hline AS201 & 0.82 & 0.839 & $74^{\circ} 04^{\prime}$ & 1.02 & 0.31 \\
\hline
\end{tabular}

to another series of Inoceramus which is outside the scope of the present study.

In the Samples TA213B, OR234 and OR233, the beak angle becomes gradually larger in ascending order, but the beak angle of Sample OR218 becomes discontinuously larger than that of Sample OR233, as in the case of the simple ratio $\mathrm{L} / \mathrm{H}$. But a transitional form in surface ornament is found at a certain horizon between those of OR233 and OR218. The schematic forms of Samples TA213B, OR242, OR234 and OR233 are illustrated in Fig. 16 and the representatives of Samples OR218 and UN101B in Fig. 15B. The latter is discriminated from UN101A by the presence of minor rings on the surface.

In the Samples UN101A, UF101 and OI213 the frequency distribution becomes gradually platykurtic in ascending order. This fact might imply the heterogeneity of species. There are, however, many intermediate forms in one sample and, therefore, the sample is hardly divided morphologically. Various forms in Samples UN101A, UF101 and OI213 are illustrated in Fig. 17. Sample OI214 shows a bimodal frequency distribution where the intermediate forms decrease.

3. Correlation between tangent $\beta / 2$ and simple ratio $L / H$.-Plotting tangent $\beta / 2$ in vertical axis and simple ratio $\mathrm{L} / \mathrm{H}$ in horizontal axis, the rejection ellipses of examined samples are shown in Fig. 18 in accordance with Table 5.

As is clear in Fig. 18, the scattered diagram of Sample TA213 consists of two separate ellipses. One (TA213B) is represented by solid circles and succeeded by Samples OR242, OR234 and OR233 with enlarged distribution in ascending order of sequence. The other (TA213A) is expressed by triangles and disappears without succeeding phenotype. In Sample OR233 the half-solid circles are referred to the specimens with special ornament of nodulous protuberance. In Sample OR218 the rejection ellipse partly overlaps those of OR234 and OR233. The range, however, fairly differs from the samples of the lower horizons. Sample UN101 is subdivided into two groups as already mentioned, of which one is represented by the solid circles only (Sample UN101B) and the other (Sample UN101A) consists 
Table 6. F-test for simple ratio $\mathrm{L} / \mathrm{H}$ at the growth stage $40 \mathrm{~mm}$ in $\mathrm{H}$.

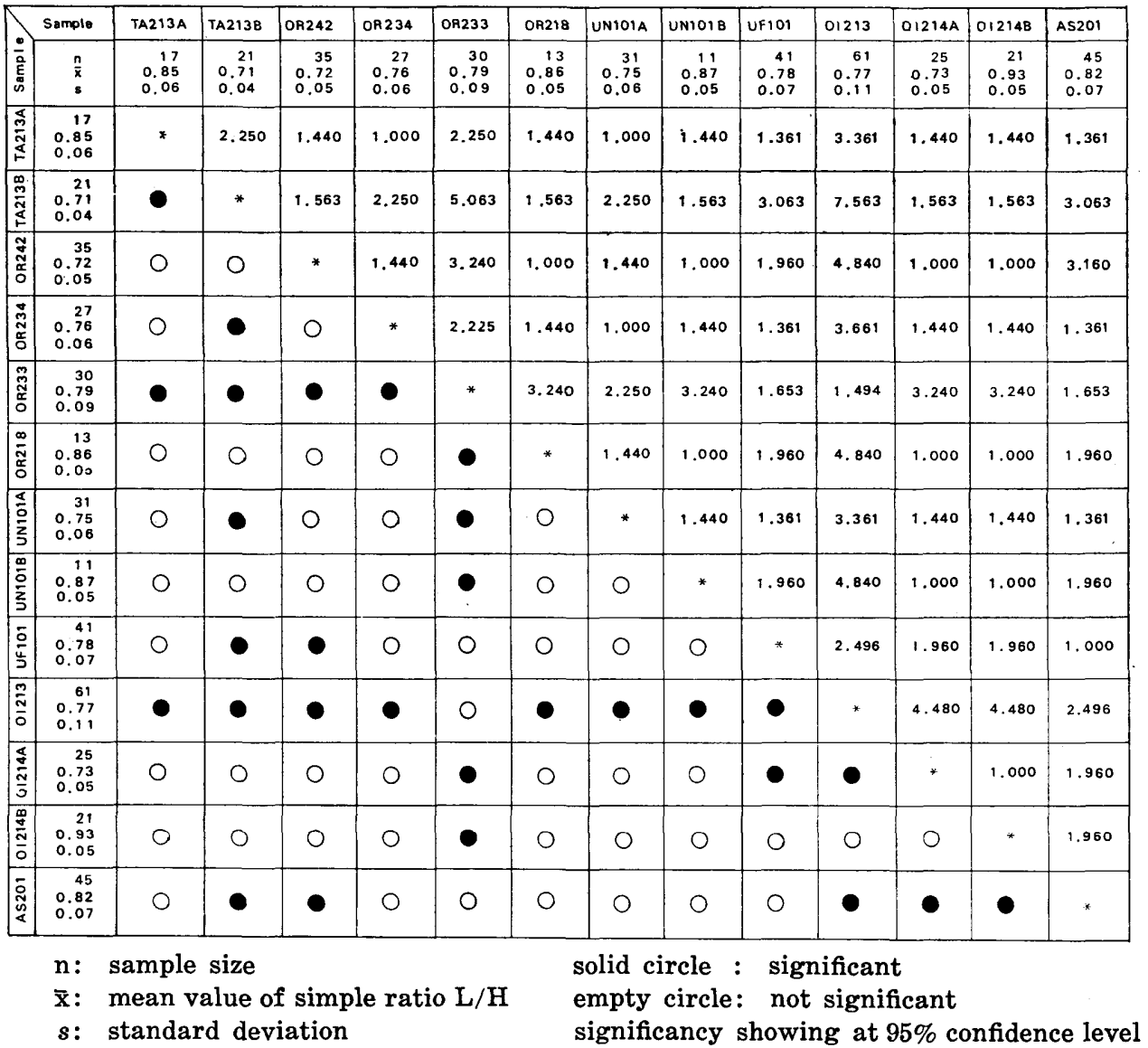

of solid and empty circles. The rejection ellipse of Sample UN101B perfectly overlaps that of Sample OR218. The form representing Sample UN101B disappears without succeeding phenotype at upper horizons. Sample UN101A consists of two phenotypes (solid circle: form with wing-like area, empty circle: form without wing-like area). The discrimination of $A$ and $B$ was due to the presence or absence of minor rings on the surface. In Sample UF101, the rejection ellipse perfectly overlaps that of Sample UN101A with more extensive distribution. Sample OI213 shows a considerable variation, but it is noteworthy that the solid circles distributed in the left-lower area. The two rejection ellipses of Sample OI214 overlap that of OI213. According to the result of chi-square test, Sample OI214 is tentatively divided into two groups. There are, however, some questions about the subdivision, since there are intermediate forms. Incidently, Sample AS201, from the upper part of the Lower Formation of the Futaba Group, shows a similar distribution in selected characters to that of OI214.

4. Results of STUDENT's $t$-test.-The results of $F$-test and STUdeNT's $t$-test for the simple ratio $\mathrm{L} / \mathrm{H}$ are shown in Tables 6 and 7 .

Samples TA213A and TA213B, UN101A and UN101B, and OI214A and 
Table 7. Student's $t$-test for simple ratio $\mathrm{L} / \mathrm{H}$ at the growth stage $40 \mathrm{~mm}$ in $\mathrm{H}$.

\begin{tabular}{|c|c|c|c|c|c|c|c|c|c|c|c|c|c|c|}
\hline 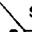 & Sample & TA213A & TA213B & OR242 & OR234 & OR233 & OR218 & UN101A & UNTO1B & UFio1 & 01213 & $01214 \mathrm{~A}$ & 012140 & AS 201 \\
\hline : & $\begin{array}{l}n \\
\bar{x} \\
s\end{array}$ & $\begin{array}{r}17 \\
0.85 \\
0.06\end{array}$ & $\begin{array}{r}21 \\
0.71 \\
0.04\end{array}$ & $\begin{array}{r}35 \\
0.72 \\
0.05\end{array}$ & $\begin{array}{r}27 \\
0.76 \\
0.06\end{array}$ & $\begin{array}{r}30 \\
0.79 \\
0.09\end{array}$ & $\begin{array}{r}13 \\
0.86 \\
0.05\end{array}$ & $\begin{array}{r}31 \\
0.75 \\
0.06\end{array}$ & $\begin{array}{r}11 \\
0.87 \\
0.05\end{array}$ & $\begin{array}{r}41 \\
0.78 \\
0.07\end{array}$ & $\begin{array}{r}61 \\
0.77 \\
0.11\end{array}$ & $\begin{array}{r}25 \\
0.73 \\
0.05\end{array}$ & $\begin{array}{r}21 \\
0.93 \\
0.05\end{array}$ & $\begin{array}{r}45 \\
0.82 \\
0.07\end{array}$ \\
\hline 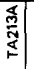 & $\begin{array}{r}17 \\
0.85 \\
0.06\end{array}$ & * & 8.284 & 8.234 & 4.845 & $\underline{2.740}$ & 1.844 & 5.522 & 0.918 & 3.606 & 3.941 & 7.042 & 4.483 & 0.855 \\
\hline $\begin{array}{c}0 \\
\frac{m}{m} \\
\frac{m}{y} \\
\frac{\alpha}{5}\end{array}$ & $\begin{array}{r}21 \\
0.71 \\
0.04\end{array}$ & & * & 0.793 & 3.472 & 4.324 & 3.256 & $\underline{2.920}$ & 9.961 & $\underline{5.036}$ & 3.636 & 1.500 & 13.879 & $\underline{8.148}$ \\
\hline 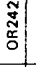 & $\begin{array}{r}35 \\
0.72 \\
0.05\end{array}$ & & 0 & * & 2.907 & 3.784 & 8.620 & 2.215 & 8.680 & 4.348 & 3.049 & 0.764 & 15.216 & 7.463 \\
\hline 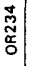 & $\begin{array}{r}27 \\
0.76 \\
0.06\end{array}$ & & & & * & 1.351 & 5.196 & 0.633 & $5.351^{\prime}$ & 1.226 & $\underline{0.594}$ & 1.951 & 10.453 & 3.707 \\
\hline $\begin{array}{c}\tilde{y} \\
\tilde{w} \\
\tilde{c} \\
0\end{array}$ & $\begin{array}{r}30 \\
0.79 \\
0.09\end{array}$ & & & & 0 & * & $\underline{3.256}$ & $\underline{2.583}$ & 3.587 & 0.694 & 0.863 & $\underline{3.125}$ & 7.107 & 1.414 \\
\hline $\begin{array}{c}\infty \\
\tilde{\tilde{\sigma}} \\
\tilde{\alpha}\end{array}$ & $\begin{array}{r}13 \\
0.86 \\
0.05 \\
\end{array}$ & 0 & & & 0 & & * & 5.810 & 0.488 & 3.813 & 4.545 & 7.604 & 3.968 & 1.918 \\
\hline \begin{tabular}{l}
\multicolumn{5}{|c}{} \\
0 \\
$z$ \\
$z$ \\
\end{tabular} & $\begin{array}{r}31 \\
0.75 \\
0.06\end{array}$ & & & (?) & 0 & (a) & 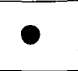 & * & 5.925 & 1.912 & 1.130 & 1.333 & 11.333 & 4.537 \\
\hline $\begin{array}{l}\frac{m}{0} \\
\bar{z} \\
\\
\end{array}$ & $\begin{array}{r}11 \\
0.87 \\
0.05 \\
\end{array}$ & 0 & & & 0 & & 0 & 0 & * & 3. 986 & 4.854 & 7.738 & 1.612 & 2.229 \\
\hline$\frac{5}{5}$ & $\begin{array}{r}41 \\
0.78 \\
0.07\end{array}$ & & & & 0 & 0 & & 0 & 0 & * & 0.562 & 3.378 & 8. 743 & 2.647 \\
\hline $\begin{array}{c}\frac{m}{2} \\
0 \\
0\end{array}$ & $\begin{array}{r}61 \\
0.77 \\
0.11\end{array}$ & & & & 0 & 0 & & 0 & 0 & 0 & * & 2.312 & 6.420 & $\underline{2.875}$ \\
\hline $\begin{array}{c}\frac{\pi}{0} \\
\frac{\pi}{3} \\
\end{array}$ & $\begin{array}{r}25 \\
0.73 \\
0.05 \\
\end{array}$ & & 0 & $\mathrm{O}$ & 0 & 0 & & 0 & 8 & 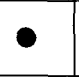 & (0) & * & 13.514 & 6.207 \\
\hline 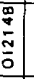 & $\begin{array}{r}21 \\
0.93 \\
0.05\end{array}$ & & & & & 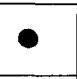 & $\mathrm{C}$ & 0 & 0 . & 0 & 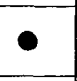 & 0 & * & 7.285 \\
\hline 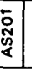 & $\begin{array}{l}.45 \\
0.82 \\
0.07\end{array}$ & 0 & & & & 0 & 0 & & () & 0 & & 0 & 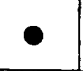 & * \\
\hline
\end{tabular}

n: sample size

$\overline{\mathrm{x}}$ : mean value of simple ratio $\mathrm{L} / \mathrm{H}$

$s$ : standard deviation

solid circle : significant double circle: less significant empty circle: not significant significancy showing at $95 \%$ confidence level underline : WeLcH's method

OI214B are very significant $\left(P>t_{0.01}\right)$ in $t$ value, Sample TA213A is not significant $\left(P<t_{0.05}\right)$ in $t$ value in the relations among the Samples OR218, UN101B and AS201, which are fairly broad forms. While, Sample TA213B is not significant in relation to OR242 and OI214A, which are much elongate along the growth axis, as are Samples OR234 to OR233, UN101A, UF101, OI213 and OI214A; and Samples OR233 to OR234, UF101, OI213 and AS201. Sample UN101A indicates insignificant values to Samples OR234, UF101, OI213 and OI214A, and less significant $\left(t_{0.05}<P<t_{0.01}\right)$ to Samples OR242 and OR233. Sample UN101B is not significant to Samples TA213A, OR218 and less significant to Sample AS201. Sample UF101 is not significant to Samples OR234, OR233, UN101A and OI213. Sample OI213 is less significant to Sample OI214A. The others are all significant between each pair.

The results of $F$-test and STUDENT's $t$-test for the beak angle are shown in Tables 8 and 9.

Samples TA213A and TA213B, UN101A and UN101B, and OI214A and OI214B respectively indicate very significant in $t$ value, as in the case of $\mathrm{L} / \mathrm{H}$. As is 
Table 8. F-test for beak angle at the growth stage $40 \mathrm{~mm}$ in $\mathrm{H}$.

\begin{tabular}{|c|c|c|c|c|c|c|c|c|c|c|c|c|c|c|}
\hline \multicolumn{2}{|c|}{ Sample } & \multirow{2}{*}{\begin{tabular}{|c|} 
TA213A \\
17 \\
99 \\
3
\end{tabular}} & \multirow{2}{*}{\begin{tabular}{|c|} 
TA213 B \\
24 \\
66 \\
4
\end{tabular}} & \multirow{2}{*}{$\begin{array}{r}\text { OR242 } \\
37 \\
68 \\
4 \\
\end{array}$} & \multirow{2}{*}{$\begin{array}{r}\text { OR234 } \\
32 \\
71 \\
6 \\
\end{array}$} & \multirow{2}{*}{$\begin{array}{r}\text { OR233 } \\
30 \\
75 \\
6 \\
\end{array}$} & \multirow{2}{*}{$\begin{array}{r}\text { OR218 } \\
13 \\
89 \\
5 \\
\end{array}$} & \multirow{2}{*}{\begin{tabular}{|c|} 
UN101A \\
30 \\
75 \\
4 \\
\end{tabular}} & \multirow{2}{*}{$\begin{array}{c}\text { UN101 B } \\
11 \\
90 \\
2 \\
\end{array}$} & \multirow{2}{*}{\begin{tabular}{|r|} 
UF101 \\
42 \\
78 \\
6 \\
\end{tabular}} & \multirow{2}{*}{\begin{tabular}{|r|}
01213 \\
55 \\
77 \\
10 \\
\end{tabular}} & \multirow{2}{*}{\begin{tabular}{|r|}
$01214 \mathrm{~A}$ \\
28 \\
73 \\
7 \\
\end{tabular}} & \multirow{2}{*}{\begin{tabular}{|c|}
012148 \\
16 \\
92 \\
2 \\
\end{tabular}} & \multirow{2}{*}{\begin{tabular}{|r|} 
AS201 \\
45 \\
80 \\
9 \\
\end{tabular}} \\
\hline 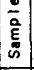 & $\begin{array}{l}n \\
\bar{y} \\
s \\
\end{array}$ & & & & & & & & & & & & & \\
\hline 离 & $\begin{array}{r}17 \\
99 \\
3 \\
\end{array}$ & * & 1.777 & 1.777 & 4.000 & 4.000 & 2.777 & 1.777 & 2.250 & 4.000 & 11.111 & 5.444 & 2.250 & 9.000 \\
\hline 密 & $\begin{array}{r}24 \\
66 \\
4 \\
\end{array}$ & 0 & * & 1.000 & 2.250 & 2.250 & 1.563 & 1.000 & 4.000 & 2.250 & 6.250 & 3.063 & 4.000 & 5.063 \\
\hline $\begin{array}{l}\tilde{y} \\
\tilde{N} \\
\tilde{x} \\
\end{array}$ & $\begin{array}{r}37 \\
68 \\
4 \\
\end{array}$ & 0 & 0 & * & 2.250 & 2.250 & 1.563 & 1.000 & 4.000 & 2.250 & 6.250 & 3.063 & 4.000 & 5.063 \\
\hline 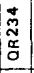 & $\begin{array}{r}32 \\
71 \\
6 \\
\end{array}$ & 0 & 0 & - & * & 1.000 & 1.440 & 2.250 & 9.000 & 1.000 & 2.778 & 1.361 & 9.000 & 2.250 \\
\hline 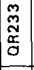 & $\begin{array}{r}30 \\
75 \\
6 \\
\end{array}$ & 0 & - & - & 0 & * & 1.440 & 2.250 & 9.000 & 1.000 & 2.778 & 1.361 & 9.000 & 2.250 \\
\hline 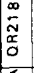 & $\begin{array}{r}13 \\
89 \\
5 \\
\end{array}$ & 0 & 0 & 0 & 0 & 0 & *. & 1.563 & 6.250 & 1.440 & 4.000 & 1.960 & 6.250 & 3.240 \\
\hline $\mid \begin{array}{l}5 \\
0 \\
2 \\
\end{array}$ & $\begin{array}{r}30 \\
75 \\
4 \\
\end{array}$ & 0 & 0 & 0 & - & - & 0 & * & 4.000 & 2.250 & 6.250 & 3.063 & 4.000 & 5.063 \\
\hline \begin{tabular}{|l|}
0 \\
0 \\
$\vdots$ \\
$z$ \\
2 \\
\end{tabular} & $\begin{array}{r}11 \\
90 \\
2 \\
\end{array}$ & 0 & - & - & - & - & - & - & * & 9.000 & 25.000 & 12.250 & 1.000 & 20.250 \\
\hline \begin{tabular}{|l|}
$\frac{0}{4}$ \\
$\frac{2}{2}$ \\
\end{tabular} & $\begin{array}{r}42 \\
78 \\
6 \\
\end{array}$ & 0 & - & - & 0 & 0 & 0 & - & - & * & 2.778 & 1.361 & 9.000 & 2.250 \\
\hline$\frac{m}{\bar{c}}$ & $\begin{array}{l}55 \\
77 \\
10 \\
\end{array}$ & - & - & - & 0 & - & - & 0 & - & - & $*$ & 2.041 & 25.000 & 1.235 \\
\hline \begin{tabular}{|c|} 
\\
$\frac{1}{2}$ \\
0 \\
0 \\
\end{tabular} & $\begin{array}{r}28 \\
73 \\
7 \\
\end{array}$ & - & 0 & - & 0 & 0 & 0 & - & - & 0 & - & * & 12.250 & 1.653 \\
\hline $\mid$ & $\begin{array}{r}16 \\
92 \\
2 \\
\end{array}$ & 0 & 0 & - & 0 & • & - & - & 0 & - & 0 & - & * & 20.250 \\
\hline 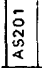 & $\begin{array}{r}45 \\
80 \\
9\end{array}$ & 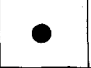 & - & 0 & ○ & - & $\bullet$ & 0 & - & - & 0 & 0 & - & * \\
\hline
\end{tabular}

$\bar{y}$ : mean value of beak angle

For others see reference of Table 6

evident from Table 9, Sample TA213A is significant in relation to all other samples. Samples TA213B, OR242, OR234 and OR233 are not significant or less significant only with respect to the sample from the next upper horizon. The fact is ascribed to the rapid and continuous enlargement of the beak angle. Sample OR218 shows insignificant value in relation to UN101B and OI214B, and are significant to other samples. Samples UN101A, UF101, OI213 and OI214A indicate insignificant or less significant value in relation to the next upper representatives. The fact suggests the continuously decreasing change of the beak angle.

5. Rib density.-The result of chi-square test of rib density is shown in Table 10, which is assigned to the normal distribution. The $F$-test and the STUDENT's $t$-test for rib density are shown in Tables 11 and 12. Samples TA213B, OR242 and OR234 indicate insignificant values in each pair respectively and Sample OR233 is not significant to OR234 and slightly significant $\left(P=t_{0.01}\right.$ or slightly more than $t_{0.01}$ ) values to Samples TA213B and OR 242. These four samples are mostly significant in relation to other samples but TA213B and OR242 are exceptionally insignificant to OI214 and less significant to AS201. While the other Samples TA213A, UN101A, UN101B, UF101, OI213, OI214 and AS201 are also mostly not or less significant or slightly significant in their relations. 
Table 9. StUdent's $t$-test for beak angle at the growth stage $40 \mathrm{~mm}$ in $\mathrm{H}$.

\begin{tabular}{|c|c|c|c|c|c|c|c|c|c|c|c|c|c|c|}
\hline 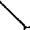 & Sample & TA213A & TA2138 & OR242 & OR234 & OR233 & OR 218 & UN101 A & UN1O1B & UF101 & 01213 & OI214A & 012148 & AS201 \\
\hline $\begin{array}{l}\frac{0}{a} \\
\bar{\varepsilon} \\
\bar{b} \\
\end{array}$ & $\begin{array}{l}n \\
\bar{y} \\
s\end{array}$ & $\begin{array}{r}17 \\
99 \\
3\end{array}$ & $\begin{array}{r}24 \\
66 \\
4\end{array}$ & $\begin{array}{r}37 \\
68 \\
4\end{array}$ & $\begin{array}{r}32 \\
71 \\
6\end{array}$ & $\begin{array}{r}30 \\
75 \\
6\end{array}$ & $\begin{array}{r}13 \\
89 \\
5\end{array}$ & $\begin{array}{r}30 \\
75 \\
4\end{array}$ & $\begin{array}{r}11 \\
90 \\
2\end{array}$ & $\begin{array}{r}42 \\
78 \\
6\end{array}$ & $\begin{array}{l}55 \\
77 \\
10\end{array}$ & $\begin{array}{r}28 \\
73 \\
7\end{array}$ & $\begin{array}{r}16 \\
92 \\
2\end{array}$ & $\begin{array}{r}45 \\
80 \\
9\end{array}$ \\
\hline 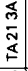 & $\begin{array}{r}17 \\
99 \\
3\end{array}$ & & 28.728 & 30.268 & 21.770 & 21.291 & 4.078 & 21.507 & 8.743 & 17.834 & 14.443 & 17.221 & 7.834 & 5.892 \\
\hline 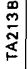 & $\begin{array}{r}24 \\
66 \\
4\end{array}$ & & * & 1.908 & $\underline{3.736}$ & 6.587 & 15.288 & 8. 294 & $\underline{23.645}$ & 9.721 & 6.980 & 4.350 & 27.157 & 8.914 \\
\hline 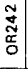 & $\begin{array}{r}37 \\
68 \\
4\end{array}$ & & 0 & * & 2.404 & 5.479 & 14.956 & 7,123 & 24.658 & 8.059 & 6.136 & 3.392 & 29.052 & 8.032 \\
\hline 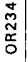 & $\begin{array}{r}32 \\
71 \\
6\end{array}$ & & & (2) & * & 2.589 & 9.538 & 3.106 & 15.574 & 4.972 & 3.497 & 1.191 & 17.909 & 5.262 \\
\hline 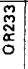 & $\begin{array}{r}30 \\
75 \\
6\end{array}$ & & & 0 & (2) & * & 7.361 & 0.000 & 19.995 & 2.092 & 0.398 & 1.171 & 14.117 & 2.887 \\
\hline \begin{tabular}{c|}
$\infty$ \\
$\underset{\sim}{\alpha}$ \\
0 \\
0
\end{tabular} & $\begin{array}{r}13 \\
89 \\
5\end{array}$ & & & & & 0 & * & 9.767 & 0.661 & 6.597 & 6.204 & 7. 390 & 2.035 & 4.664 \\
\hline $\begin{array}{l} \\
0 \\
0 \\
3 \\
\end{array}$ & $\begin{array}{r}30 \\
75 \\
4\end{array}$ & & & & & 0 & 0 & * & 15.838 & 2.544 & 1.304 & 1.324 & 21.703 & 3.273 \\
\hline $\begin{array}{l}\frac{\infty}{0} \\
\bar{z} \\
\end{array}$ & $\begin{array}{r}11 \\
90 \\
2\end{array}$ & & & & & & 0 & 0 & * & 10.429 & 8.734 & 11.693 & 2.553 & 6.799 \\
\hline$\frac{\bar{o}}{\frac{5}{5}}$ & $\begin{array}{r}42 \\
78 \\
6\end{array}$ & & & & & & 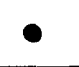 & (C) & 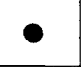 & * & 0.611 & 3.194 & 13.305 & 1.227 \\
\hline$\frac{m}{\bar{a}}$ & $\begin{array}{l}55 \\
77 \\
10\end{array}$ & & & & & & 0 & 0 & 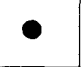 & 0 & * & 2.118 & 9.735 & 1.561 \\
\hline $\begin{array}{l}\frac{\pi}{0} \\
\frac{\pi}{4} \\
\end{array}$ & $\begin{array}{r}28 \\
73 \\
7\end{array}$ & & & & 0 & 0 & 0 & 0 & & 0 & (C) & * & 13.435 & 3.503 \\
\hline \begin{tabular}{l} 
足 \\
\multirow{2}{*}{} \\
0 \\
0
\end{tabular} & $\begin{array}{r}16 \\
92 \\
2\end{array}$ & & & & & & 0 & & & 0 & C & 0 & * & 8.381 \\
\hline 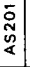 & $\begin{array}{r}45 \\
80 \\
9\end{array}$ & & & & & & & & & 0 & 0 & 0 & ? & * \\
\hline
\end{tabular}

$\bar{y}$ : mean value of beak angle

For others see reference of Table 7

Table 10. Chi-square test for rib density.

\begin{tabular}{|l|r|r|c|c|c|}
\hline Sample & $\mathrm{N}$ & mean & $s$ & $\mathrm{~V}$ & $X^{2}$ \\
\hline TA213 & 12 & 6.1 & 1.78 & 29.18 & 2.68 \\
OR242 & 8 & 4.4 & 0.92 & 20.90 & 1.14 \\
OR234 & 11 & 3.8 & 0.87 & 22.89 & 4.05 \\
OR233 & 19 & 3.4 & 0.58 & 17.06 & 6.11 \\
OR218 & 8 & 7.1 & 0.83 & 11.69 & 5.59 \\
UN101 & 8 & 7.0 & 0.76 & 10.86 & 2.27 \\
UF101 & 9 & 6.4 & 0.73 & 11.41 & 2.86 \\
OI213 & 8 & 6.4 & 0.74 & 11.56 & 2.06 \\
OI214 & 4 & 5.5 & 0.58 & 10.55 & 6.23 \\
AS201 & 11 & 5.5 & 0.82 & 14.91 & 1.23 \\
\hline
\end{tabular}

N: sample size

$s:$ standard deviation

V: Pearson's coefficient of variation

$X^{2}$ : chi-square value 
Table 11. F-test for rib density at the growth stage between $30 \mathrm{~mm}$ and $60 \mathrm{~mm}$ in $\mathrm{H}$.

\begin{tabular}{|c|c|c|c|c|c|c|c|c|c|c|c|c|c|}
\hline & Sample & TA213A & TA213B & OR242 & OR234 & OR233 & OR218 & UN101A & UN1018 & UF101 & 01213 & 01214 & AS 201 \\
\hline $\begin{array}{l}\frac{0}{a} \\
\bar{\varepsilon} \\
\text { है }\end{array}$ & $\begin{array}{l}\frac{n}{d} \\
s\end{array}$ & $\begin{array}{r}7 \\
7.3 \\
1.20\end{array}$ & $\begin{array}{r}5 \\
4.4 \\
0.89\end{array}$ & $\begin{array}{r}8 \\
4.4 \\
0.92\end{array}$ & $\begin{array}{r}11 \\
3.8 \\
0.87\end{array}$ & $\begin{array}{r}19 \\
3.4 \\
0.58\end{array}$ & $\begin{array}{r}8 \\
7.1 \\
0.83\end{array}$ & $\begin{array}{r}4 \\
7.0 \\
0.76\end{array}$ & $\begin{array}{r}7 \\
7.0 \\
0.75\end{array}$ & $\begin{array}{r}9 \\
6.4 \\
0.73\end{array}$ & $\begin{array}{r}8 \\
6.4 \\
0.74\end{array}$ & $\begin{array}{r}4 \\
5.5 \\
0.58\end{array}$ & $\begin{array}{r}11 \\
5.5 \\
0.82\end{array}$ \\
\hline 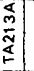 & $\begin{array}{r}7 \\
7.3 \\
1.20\end{array}$ & * & 1.817 & 1.701 & 1.902 & 4.281 & 2.090 & 2.493 & 2.560 & 2.702 & 2.638 & 4.281 & 2.142 \\
\hline $\begin{array}{l}\frac{\infty}{2} \\
\frac{\pi}{N} \\
\leqslant\end{array}$ & $\begin{array}{r}5 \\
4.4 \\
0.89\end{array}$ & 0 & * & 1.069 & 1.047 & 2.356 & 1.150 & 1.371 & 1.408 & 1.486 & 1.446 & 2.356 & 1.187 \\
\hline 㺃 & $\begin{array}{r}8 \\
4.4 \\
0.92\end{array}$ & 0 & 0 & * & 1.118 & 2.516 & 1.229 & 1.465 & 1.505 & 1.588 & 1.546 & 2.516 & 1.259 \\
\hline 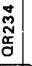 & $\begin{array}{r}11 \\
3.8 \\
0.87\end{array}$ & 0 & 0 & 0 & * & 2.250 & 1.099 & 1.310 & 1.346 & 1.420 & 1.382 & 2.250 & 1.126 \\
\hline 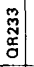 & $\begin{array}{r}19 \\
3.4 \\
0.58\end{array}$ & 0 & 0 & 0 & 0 & * & 2.048 & 1.717 & 1.672 & 1.584 & 1.628 & 1.000 & 1.999 \\
\hline 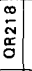 & $\begin{array}{r}8 \\
7.1 \\
0.83\end{array}$ & 0 & 0 & 0 & 0 & 0 & * & 1.193 & 1.225 & 1. 293 & 1.258 & 2.068 & 1.025 \\
\hline 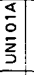 & $\begin{array}{r}4 \\
7.0 \\
0.76 \\
\end{array}$ & 0 & 0 & 0 & 0 & 0 & 0 & $*$ & 1.028 & 1.084 & 1.055 & 1.717 & 1.164 \\
\hline $\begin{array}{l}\frac{m}{2} \\
\overline{2} \\
\underline{3} \\
\end{array}$ & $\begin{array}{r}4 \\
7.0 \\
0.75\end{array}$ & 0 & 0 & 0 & 0 & 0 & 0 & 0 & * & 1.056 & 1.027 & 1.672 & 1.195 \\
\hline$\frac{-}{0}$ & $\begin{array}{r}9 \\
6.4 \\
0.73\end{array}$ & 0 & 0 & 0 & 0 & 0 & 0 & 0 & 0 & * & 1.028 & 1.584 & 1.262 \\
\hline$\frac{m}{\frac{3}{0}}$ & $\begin{array}{r}8 \\
6.4 \\
0.74\end{array}$ & 0 & 0 & 0 & $\mathrm{O}$ & 0 & 0 & 0 & 0 & 0 & * & 1.628 & 1.228 \\
\hline$\frac{0}{ \pm}$ & $\begin{array}{r}4 \\
5.5 \\
0.58 \\
\end{array}$ & 0 & 0 & 0 & 0 & 0 & 0 & 0 & 0 & 0 & 0 & * & 1.999 \\
\hline 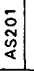 & $\begin{array}{r}11 \\
5.5 \\
0.82\end{array}$ & 0 & 0 & 0 & 0 & 0 & 0 & 0 & 0 & $\mathrm{O}$ & 0 & 0 & * \\
\hline
\end{tabular}

$\overline{\mathrm{d}}$ : mean value of rib density

For others see reference of Table 6

6. Pattern of average relative growth.-As is mentioned in the preceding section, the examined specimens are more than $10 \mathrm{~mm}$ in $\mathrm{H}$, and the two variables of $\mathrm{H}$ and $\mathrm{L}$ do not mean the maximum shell height $(\mathrm{h})$ and shell length (l) (see Fig. 8).

As is evident from Fig. 19, in the relative growth of $\mathrm{H}$ and $\mathrm{L}$ the reduced major axis of every sample is monophasic without critical point. The relative growth of bivalvia, however, generally shows abrupt change at a certain growth stage in various characters.

The scattered diagrams of the samples overlap one another.

In Samples TA213B, OR242, OR234 and OR233, the scattering areas slide to the lower right little by little with time. Samples OR233, UN101A, UF101, OI213 and OI214A also overlap one another but there is no regularity as to the relation of the samples TA213B, OR242, OR234 and OR233. In pairs of Samples UN101A and $\mathrm{UN101B}$, and those of OI213A and OI214B, the reduced major axes mostly overlap each other in the early stage of growth, but are gradually separated with growth respectively.

7. Surface ornamentation.-Although in Inoceramus (s. 1.) the surface ornamentations are not suitable character for mensuration, only the number of ribs with growth is examined statistically. 
Table 12. STUDENT's $t$-test for rib density at the growth stage between $30 \mathrm{~mm}$ and $60 \mathrm{~mm}$ in $\mathrm{H}$.

\begin{tabular}{|c|c|c|c|c|c|c|c|c|c|c|c|c|c|}
\hline & Sample & TA213A & TA213B & QR242 & OR 234 & QR233 & OR2 18 & UN101A & UN101B & UF 101 & 01213 & 01214 & AS201 \\
\hline 竭 & $\begin{array}{l}\frac{n}{d} \\
s\end{array}$ & $\begin{array}{r}7 \\
7.3 \\
1.20\end{array}$ & $\begin{array}{r}5 \\
4.4 \\
0.89 \\
\end{array}$ & $\begin{array}{r}8 \\
4.4 \\
0.92 \\
\end{array}$ & $\begin{array}{r}11 \\
3.8 \\
0.87\end{array}$ & $\begin{array}{r}19 \\
3.4 \\
0.58\end{array}$ & $\begin{array}{r}8 \\
7.1 \\
0.83\end{array}$ & $\begin{array}{r}4 \\
7.0 \\
0.76\end{array}$ & $\begin{array}{r}74 \\
7.70 \\
0.75\end{array}$ & $\begin{array}{r}9 \\
6.4 \\
0.73 \\
\end{array}$ & $\begin{array}{r}8 \\
6.4 \\
0.74\end{array}$ & $\begin{array}{r}4 \\
5.5 \\
0.58\end{array}$ & $\begin{array}{r}11 \\
5.5 \\
0.82 \\
\end{array}$ \\
\hline 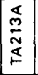 & $\begin{array}{r}7 \\
7.3 \\
1.20\end{array}$ & $*$ & 4.558 & 5,296 & 7.192 & 8.850 & 0.373 & 0.415 & 0.447 & 1.861 & 1.775 & 2.774 & 3.799 \\
\hline 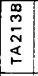 & $\begin{array}{r}5 \\
4.4 \\
0.89\end{array}$ & 0 & * & 0.000 & 1.270 & 3.073 & 5.557 & 4.632 & 4.653 & 4.556 & 4.397 & 2.123 & 2,426 \\
\hline 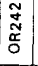 & $\begin{array}{r}8 \\
4.4 \\
0.92 \\
\end{array}$ & 0 & 0 & * & 1.449 & 3. 428 & 6.163 & 4.852 & 5.578 & 4.994 & 4.791 & 2.157 & 2,279 \\
\hline 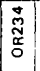 & $\begin{array}{r}11 \\
3.8 \\
0.87\end{array}$ & 0 & 0 & $\mathrm{O}$ & * & 1.513 & 8.318 & 7.660 & 6.495 & 7.134 & 6.832 & 3.584 & 4.716 \\
\hline$\underset{\substack{\tilde{\pi} \\
0 \\
0}}{m}$ & $\begin{array}{r}19 \\
3.4 \\
0.58\end{array}$ & 0 & & & 0 & * & 13.309 & 11.509 & 10.777 & 11.768 & 11.318 & 6.582 & 8. 214 \\
\hline$\frac{\infty}{\tilde{\pi}}$ & $\begin{array}{r}8 \\
7.1 \\
0.83\end{array}$ & 0 & & & & & * & 0.202 & 0.202 & 1.851 & 1.780 & 3.422 & 3.443 \\
\hline $\begin{array}{l}\frac{5}{2} \\
\frac{2}{2}\end{array}$ & $\begin{array}{r}4 \\
7.0 \\
0.76 \\
\end{array}$ & 0 & & & & & 0 & * & 0.000 & 1.412 & 1. 393 & 3.138 & 3.185 \\
\hline$\frac{0}{2}$ & $\begin{array}{r}4 \\
7.0 \\
0.75 \\
\end{array}$ & 0 & & & & & 0 & 0 & * & 1.418 & 1.331 & 3.164 & 3.194 \\
\hline$\frac{5}{5}$ & $\begin{array}{r}9 \\
6.4 \\
0.73 \\
\end{array}$ & 0 & & 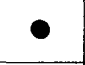 & & & 0 & 0 & 0 & $*$ & 0.000 & 2.163 & 2.563 \\
\hline$\frac{m}{\frac{m}{0}}$ & $\begin{array}{r}8 \\
6.4 \\
0.74\end{array}$ & 0 & & 0 & & & $\mathrm{O}$ & 0 & 0 & $\mathrm{O}$ & * & 2.112 & 2.459 \\
\hline$\frac{0}{2}$ & $\begin{array}{r}4 \\
5.5 \\
0.58\end{array}$ & (C) & 0 & 0 & & & 0 & (C) & (2) & 0 & $\mathrm{O}$ & $*$ & 0.000 \\
\hline 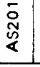 & $\begin{array}{r}11 \\
5.5 \\
0.82 \\
\end{array}$ & & (a) & () & & & & 0 & 0 & (a) & () & 0 & * \\
\hline
\end{tabular}

$\bar{d}$ : mean value of rib density

For others see reference of Table 7

Samples OR234 and OR233, which represent Inoceramus hobetsensis as explained in another chapter, consist of specimens of various sizes, containing individuals larger than $100 \mathrm{~mm}$ in $\mathrm{H}$, sometimes larger than $400 \mathrm{~mm}$. Their surface is ornamented with strong and coarse concentric ribs or undulations and also minor concentric rings. The rib density commonly changes with growth as shown in Table 13. The numerals express the total number of the ribs in the indicated $H$ respectively.

As is clarified from Table 13, the rib density abruptly becomes lower between $100 \mathrm{~mm}$ and $150 \mathrm{~mm}$ in $\mathrm{H}$. This inclination is not recognized in the specimens of other samples.

8. Chronological change of ornaments.-Samples TA213B, OR242, OR234 and OR233 continuously and gradually change in surface ornamentation with time as in shell outline. As shown in Table 14, three morphotypes are recognized and their frequency distribution changes with time, that is, Sample TA213B consists of two forms i.e. nonsulcate and sulcate forms in percentage of 33.3 and 66.7 (in number of 5 and 10) respectively. The former gradually decreases in frequency with time, whereas, the latter increases in Samples OR242 and OR234. A new form with nodulous protuberance appears in Sample OR234 and it increases in number in Sample OR233 and at OR 230. 

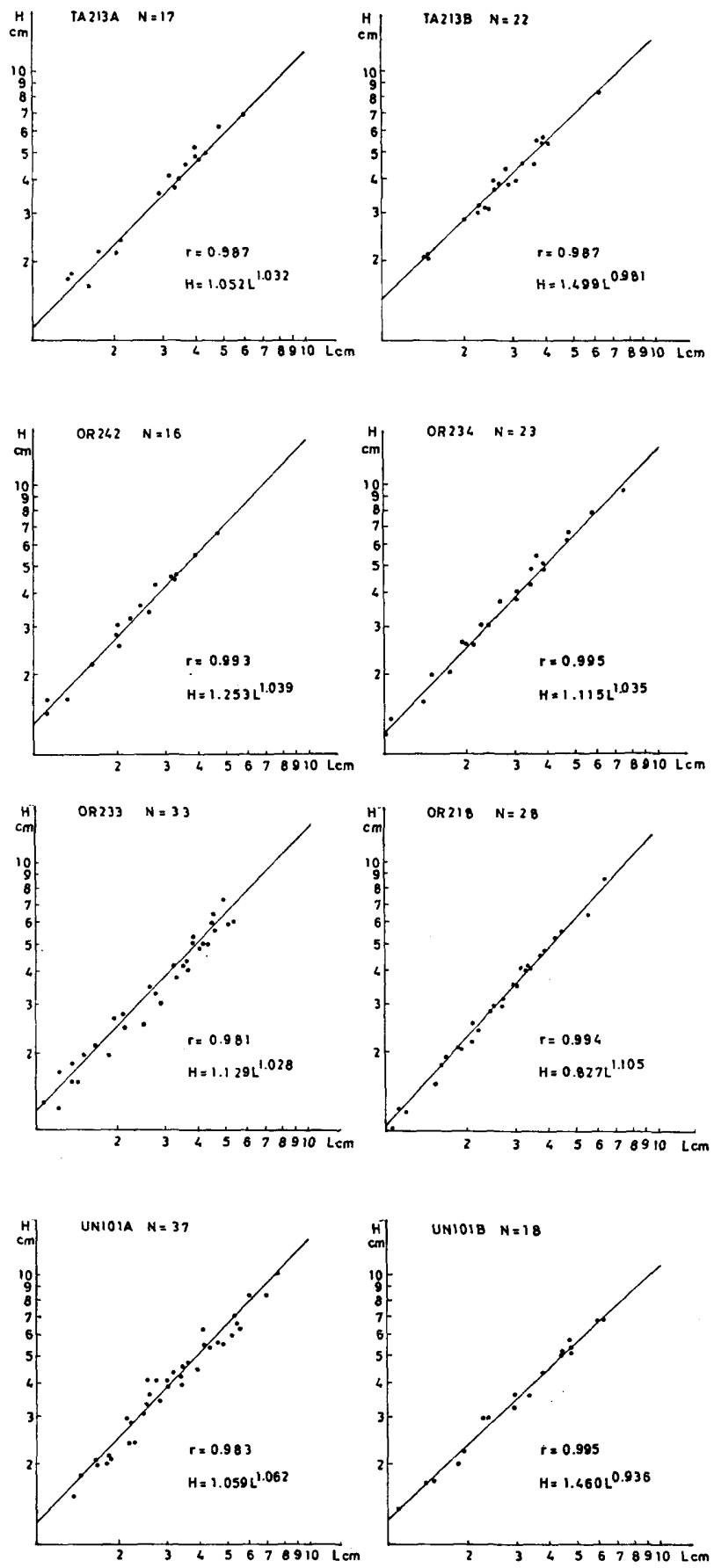

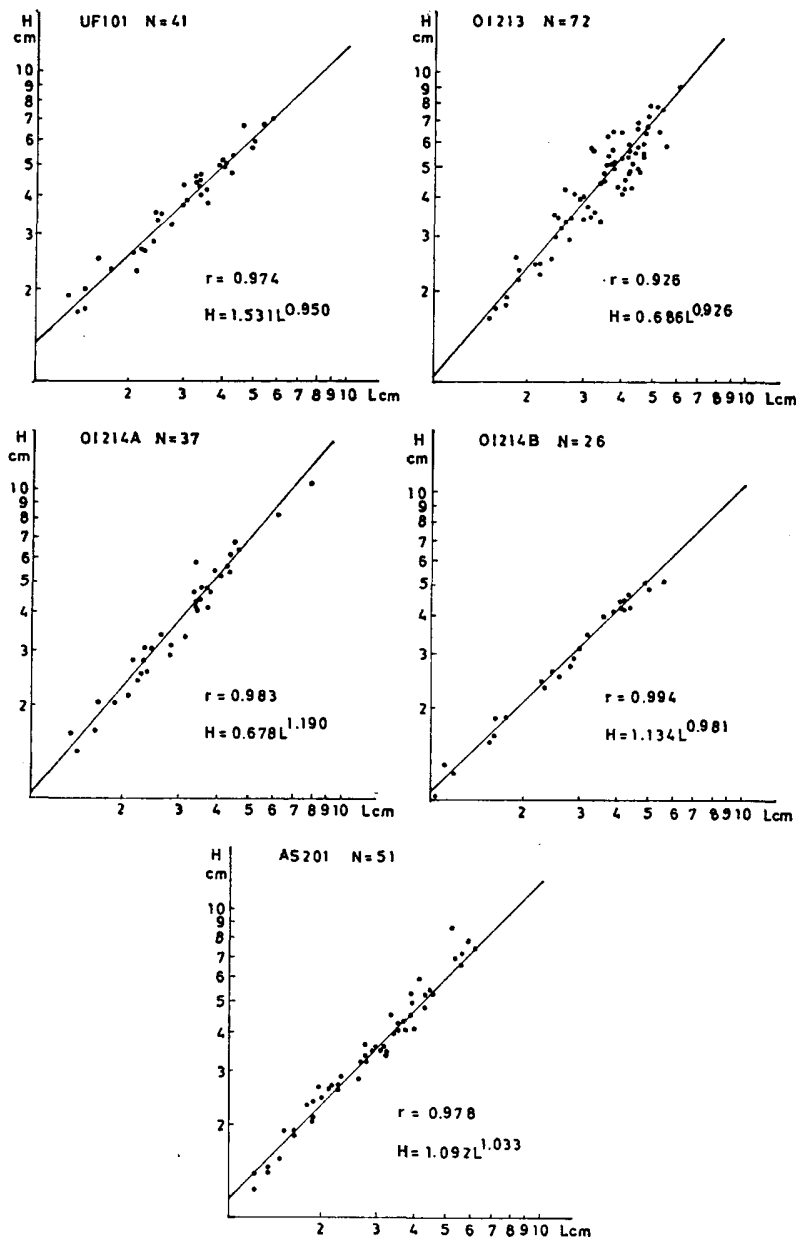

Fig. 19. Reduced major axis of $\mathrm{L}$ to $\mathrm{H}$ for each sample.

The various kinds of ornament of the above samples are schematically illustrated in Fig. 20.

\section{Infraspecific Distinction}

MAYR et al. (1953) proposed the 75 percent rule as a conventional level of subspecific distinction, and it is convenient to apply this rule to the biometrically examined characters.

The term "subspecies" is available to a certain grade of geographical variation of recent species, but it is doubtful to apply the same term to the so-called chronological subspecies or transients in fossil species. Anyhow, the 75 percent rule is used conventionally to find distinction between successive samples in the present study.

The results of evaluation of $\mathbf{7 5}$ percent rule for the characters of simple ratio $\mathrm{L} / \mathrm{H}$, beak angle and rib density are shown in Tables 15, 16 and 17. The result of 
Table 13. Number of ribs with growth.

\begin{tabular}{|c|c|c|c|c|c|c|}
\hline \multicolumn{2}{|c|}{ growth stage $(\mathrm{mm}$ in H) } & 50 & 100 & 150 & 200 & 250 \\
\cline { 1 - 6 } specimen & Loc. & & & & & \\
\cline { 1 - 4 } JG. H 2010 & OR 234 & 6 & 10 & - & - & - \\
JG. H 2022 & OR 233 & 7 & 10 & 12 & - & - \\
JG. H 2023 & OR 233 & 5 & 9 & 11 & - & - \\
JG. H 2024 & OR 233 & 7 & 9 & 11 & 12 & 13 \\
JG. H 2028 & OR 233 & 7 & 10 & 12 & 13 & 14 \\
JG. H 2029 & OR 234 & 6 & 9 & 11 & 13 & - \\
JG. H 2030 & OR 233 & 6 & 9 & - & - & - \\
JM 101 & OR 233 & 5 & 9 & - & - & - \\
MK 108 & OR 233 & 6 & 9 & 11 & 12 & - \\
\hline
\end{tabular}

Table 14. Chronological change of frequency of surface ornamentations in selected samples from various horizons.

\begin{tabular}{|l|r|r|r|r|r|r|r|}
\hline \multirow{2}{*}{ Sample } & \multirow{2}{*}{$\begin{array}{c}\text { sample } \\
\text { zize }\end{array}$} & \multicolumn{2}{|c|}{ nonsulcate form } & \multicolumn{2}{c|}{ sulcate form } & \multicolumn{2}{c|}{ nodulous form } \\
\cline { 3 - 8 } & & $\mathrm{N}$ & $\%$ & $\mathrm{~N}$ & $\%$ & $\mathrm{~N}$ & $\%$ \\
\hline OR230 & 65 & 3 & 5.5 & 40 & 61.1 & 22 & 33.4 \\
OR233 & 164 & 11 & 6.5 & 112 & 68.8 & 41 & 24.7 \\
OR234 & 123 & 24 & 19.3 & 92 & 74.5 & 7 & 5.9 \\
OR242 & 47 & 12 & 25.5 & 35 & 74.5 & 0 & 0.0 \\
TA213B & 15 & 5 & 33.3 & 10 & 66.7 & 0 & 0.0 \\
\hline
\end{tabular}

(Sample OR230 obtained at a horizon about $70 \mathrm{~m}$ above that of OR233)

STUDENT's $t$-test does not always agree with that of 75 percent rule, as has already been remarked by HAYAMI (1969).

From the result of 75 percent rule for the simple ratio $\mathrm{L} / \mathrm{H}$, the relation in pair samples marked by solid circle is significant as shown in Table 15.

As to the beak angle, as shown in Table 16, Sample TA213A is significantly unrelated with all other samples except OR218. Sample TA213A is thus discriminated from other samples. Every pair between TA213B, OR 242, OR234 and OR233 is not significantly related with each other. The fact indicates that these four samples are not infraspecifically discriminated from one another, but discriminated from OR218 and UN101B.

Samples OR218 and UN101B are closely related with each other and are clearly discriminated from other samples.

Every pair between Samples UN101A, UF101, OI213 and OI214 is not significantly related with each other, which is not either discriminated from Samples TA213B, OR242, OR234 and OR233.

On the rib density, as shown in Table 17, Sample TA213A is clearly discriminated from Samples TA213B, OR242, OR234 and OR233, and the latter four samples are not discriminated from one another. Samples TA213A, OR218, UN101A, UN101B, OI213 and OI214 are not either discriminated from one another.

In general, the infraspecific criteria of Inoceramus depend on the characters which are unsuitable for numerical examination. For example, the surface orna- 

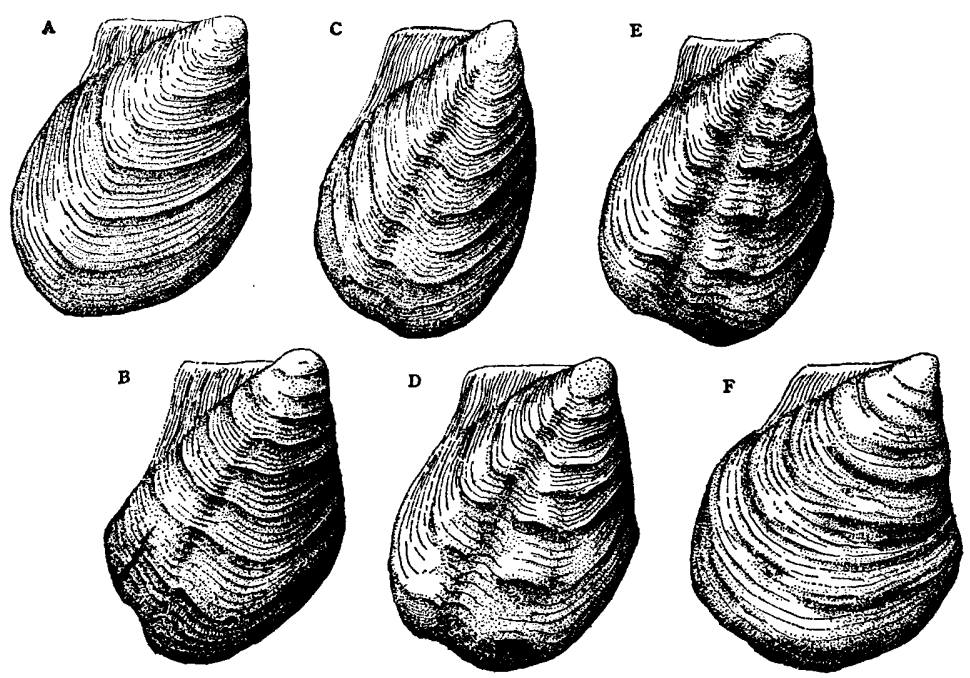

Fig. 20. Chronological change of surface ornamentation in the Middle Turonian Inoceramus hobetsensis.

A: nonsulcate form, B: form with an incipient radial depression, C: form with a radial depression, D: form with nodulous protuberance on either side of the radial depression, $\mathbf{E}$ : form with nodulous protuberance appeared in early growth stage, F: from with irregular concentric ornaments.

mentation is important as a criterion of infraspecific discrimination. The shortcut method is applicable to such characters as indicated in Tables 18 and 19.

Calculating from the data of Table 18, the random variables $\left(X^{2}\right)$ between Samples OR233 and OR234 is 10.762, that is more than 5 percent significant limit, while the value between Samples OR234 and OR242 is less than 5 percent significant limit, i.e. $\left(X^{2}\right)=0.738$.

I would regard that the presence or absence of the radial depression is significant for infraspecific discrimination between OR234 and OR233. The above examination proves quantitatively the rationality of the discrimination of Inoceramus hobetsensis var. nonsulcatus NAGAO et MATSUMOTO from the typical form.

According to Table 19, the random variable $\left(X^{2}\right)$ between Samples OR233 and OR234 is also larger than a value of 5 percent significant limit, i.e. $\left(X^{2}\right)=$ 18.815, whereas the one between Samples OR234 and OR242 is less than the significant limit, i.e. $\left(X^{2}\right)=2.789$. This fact suggests that the nodulous character is also applicable as a criterion for infraspecific discrimination. The above two facts, as indicated in Tables 18 and 19, suggest that a phylogenetical change must have occurred at a certain time between the beds of OR234 and OR233.

The summary of the above evaluation is shown in Table 20 and my conclusion of the specific and infraspecific classification is as follows.

Sample TA213A is discriminated from all other samples in the examined characters. This is referred to Inoceramus teraokai MATsumoto et NoDA, which probably belongs to different stock from any other samples.

Samples of TA213B, OR242 and OR234 are indistinguishable from one another with respect to the examined characters. They altogether represent a particular stage in the phylogenetical series of Inoceramus hobetsensis NAGAO et MATSU- 
Table 15. Coefficient of difference (simple ratio $\mathrm{L} / \mathrm{H}$ ).

\begin{tabular}{|c|c|c|c|c|c|c|c|c|c|c|c|c|c|}
\hline & Sample & TA213A & TA213B & OR242 & OP234 & $\mathrm{OP} 233$ & OR218 & UNIOIA & UN101B & UF 101 & 01213 & 01214 & AS201 \\
\hline 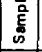 & $\begin{array}{l}\overline{\bar{x}} \\
s \\
\end{array}$ & $\begin{array}{l}0.85 \\
0.06 \\
\end{array}$ & $\begin{array}{l}0.71 \\
0.04\end{array}$ & $\begin{array}{l}0.72 \\
0.05\end{array}$ & $\begin{array}{l}0.76 \\
0.06\end{array}$ & $\begin{array}{l}0.79 \\
0.09\end{array}$ & $\begin{array}{l}0.86 \\
0.05\end{array}$ & $\begin{array}{l}0.75 \\
0.06\end{array}$ & $\begin{array}{l}0.87 \\
0.05\end{array}$ & $\begin{array}{l}0.78 \\
0.07\end{array}$ & $\begin{array}{l}0.77 \\
0.11\end{array}$ & $\begin{array}{l}0.82 \\
0.11\end{array}$ & $\begin{array}{l}0.82 \\
0.07\end{array}$ \\
\hline 敢 & $\begin{array}{l}0.85 \\
0.06 \\
\end{array}$ & * & 1.400 & 1.182 & 0.750 & 0.400 & 0.091 & 0.833 & 0.182 & 0.538 & 0.471 & 0.176 & 0.231 \\
\hline 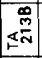 & $\begin{array}{l}0.71 \\
0.04\end{array}$ & 0 & * & 0.311 & 0.500 & 0.615 & 1.667 & 0.400 & 1.778 & 0.636 & 0.400 & 0.733 & 1.000 \\
\hline ๔ू্ & $\begin{array}{l}0.72 \\
0.05\end{array}$ & 0 & 0 & . & 0.353 & 0.500 & 1.400 & 0.237 & 1.500 & 0.500 & 0.313 & 0.625 & 0.833 \\
\hline 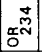 & $\begin{array}{l}0.76 \\
0.06 \\
\end{array}$ & 0 & 0 & 0 & , & 0.200 & 0.903 & 0.083 & 1.000 & 0.154 & 0.059 & 0.353 & 0.462 \\
\hline ๘ल & $\begin{array}{l}0.79 \\
0.09 \\
\end{array}$ & 0 & 0 & 0 & 0 & * & 0.500 & 0.267 & 0.571 & 0.063 & 0.100 & 0.150 & 0.188 \\
\hline$\sigma_{0}^{\infty}$ & $\begin{array}{l}0.86 \\
0.05\end{array}$ & 0 & 0 & 0 & 0 & 0 & * & 1.000 & 0.100 & 0.667 & 0.563 & 0.250 & 0.333 \\
\hline$z^{4}=$ & $\begin{array}{l}0.75 \\
0.06\end{array}$ & $\mathrm{O}$ & 0 & 0 & 0 & 0 & 0 & * & 1.091 & 0.231 & 0.118 & 0.412 & 0.538 \\
\hline 20 & $\begin{array}{l}0.87 \\
0.05 \\
\end{array}$ & 0 & 0 & 0 & 0 & 0 & 0 & 0 & * & 0.750 & 0.625 & 0.313 & 0.417 \\
\hline$=$ & $\begin{array}{l}0.78 \\
0.07 \\
\end{array}$ & 0 & 0 & 0 & 0 & 0 & 0 & 0 & 0 & * & 0.056 & 0.222 & 0.286 \\
\hline$-\frac{m}{2}$ & $\begin{array}{l}0.77 \\
0.11\end{array}$ & 0 & 0 & 0 & 0 & 0 & 0 & 0 & 0 & 0 & * & 0.227 & 0.287 \\
\hline$\frac{0^{\circ}}{\frac{\pi}{N}}$ & $\begin{array}{l}0.82 \\
0.11\end{array}$ & 0 & 0 & 0 & 0 & 0 & 0 & 0 & 0 & 0 & 0 & * & 0.000 \\
\hline कृष्त & $\begin{array}{l}0.82 \\
0.07\end{array}$ & 0 & 0. & 0 & 0 & 0 & 0 & 0 & 0 & 0 & 0 & 0 & * \\
\hline
\end{tabular}

$\overline{\mathrm{x}}$ : mean value of simple ratio $\mathrm{L} / \mathrm{H}$

$s$ : standard deviation

solid circle : significant

empty circle: not significant

Table 16. Coefficient of difference (beak angle).

\begin{tabular}{|c|c|c|c|c|c|c|c|c|c|c|c|c|c|}
\hline 5 & Sample & TA213A & TA2138 & OR242 & OR234 & OR233 & OR218 & UN101A & UN101 $\mathrm{B}$ & UF101 & 01213 & 01214 & AS20 1 \\
\hline 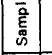 & $\begin{array}{l}\vec{y} \\
\mathbf{s}\end{array}$ & $\begin{array}{r}99 \\
3 \\
\end{array}$ & $\begin{array}{r}66 \\
4 \\
\end{array}$ & $\begin{array}{r}68 \\
4 \\
\end{array}$ & $\begin{array}{r}71 \\
6\end{array}$ & $\begin{array}{r}75 \\
6 \\
\end{array}$ & $\begin{array}{r}89 \\
5 \\
\end{array}$ & $\begin{array}{r}75 \\
4 \\
\end{array}$ & $\begin{array}{r}90 \\
2 \\
\end{array}$ & $\begin{array}{r}78 \\
6\end{array}$ & $\begin{array}{l}77 \\
10\end{array}$ & $\begin{array}{l}80 \\
11 \\
\end{array}$ & $\begin{array}{r}80 \\
9 \\
\end{array}$ \\
\hline $\mathbb{E}^{\mathbb{m}}$ & $\begin{array}{r}99 \\
3 \\
\end{array}$ & * & 4.714 & 4.571 & 3.111 & 2.667 & 1.250 & 3.429 & 1.800 & 2.333 & 1.692 & 1.337 & 1.583 \\
\hline 象 & $\begin{array}{r}66 \\
4 \\
\end{array}$ & 0 & * & 0.250 & 0.500 & 0.900 & 2.555 & 1.125 & 4.000 & 1.200 & 0.786 & 0.933 & 1.077 \\
\hline$x_{0}^{\mathbb{N}}$ & $\begin{array}{r}68 \\
4 \\
\end{array}$ & 0 & 0 & * & 0.300 & 0.700 & 2.333 & 0.875 & 3.667 & 1.000 & 0.643 & 0.800 & 0.923 \\
\hline 恕 & $\begin{array}{r}71 \\
6 \\
\end{array}$ & 0 & 0 & 0 & * & 0.333 & 1.636 & 0.400 & 2.375 & 0.583 & 0.375 & 0.529 & 0.600 \\
\hline x. & $\begin{array}{r}75 \\
6 \\
\end{array}$ & 0 & 0 & 0 & 0 & * & 1.272 & 0.000 & 1.875 & 0.250 & 0.125 & 0.294 & 0.333 \\
\hline${ }_{0}^{\infty} \stackrel{\infty}{N}$ & $\begin{array}{r}89 \\
5 \\
\end{array}$ & 0 & 0 & 0 & - & - & * & 1.555 & 0.143 & 1.000 & 0.800 & 0.563 & 0.643 \\
\hline$z^{5}$ & $\begin{array}{r}75 \\
4 \\
\end{array}$ & $\bullet$ & 0 & 0 & 0 & 0 & 0 & * & 2.500 & 0.300 & 0.143 & 0.333 & 0.385 \\
\hline$z^{\infty} \overline{0}$ & $\begin{array}{r}90 \\
2 \\
\end{array}$ & 0 & - & 0 & - & $\bullet$ & 0 & 0 & * & 1.500 & 1.083 & 0.769 & 0.909 \\
\hline 훔 & $\begin{array}{r}78 \\
6\end{array}$ & $\bullet$ & 0 & 0 & 0 & 0 & 0 & 0 & 0 & * & 0.063 & 0.118 & 0.133 \\
\hline $0^{\frac{m}{N}}$ & $\begin{array}{l}77 \\
10 \\
\end{array}$ & $\bullet$ & 0 & 0 & 0 & 0 & 0 & 0 & 0 & 0 & * & 0.143 & 0.158 \\
\hline $0^{\frac{\pi}{N}}$ & $\begin{array}{l}80 \\
11\end{array}$ & 0 & 0 & 0 & 0 & 0 & 0 & 0 & 0 & 0 & 0 & * & 0.000 \\
\hline पi & $\begin{array}{r}80 \\
9\end{array}$ & 0 & 0 & 0 & 0 & 0 & 0 & 0 & 0 & 0 & 0 & 0 & * \\
\hline
\end{tabular}

$\bar{y}$ : mean value of beak angle

For others see reference of Table $\mathbf{1 5}$ 
Table 17. Coefficient of difference (rib density).

\begin{tabular}{|c|c|c|c|c|c|c|c|c|c|c|c|c|c|}
\hline 0 & Sample & TA213A & TA 213 B & OR242 & OR234 & OR233 & 0 O218 & UNIOIA & UN101B & UF101 & 01213 & 01214 & AS201 \\
\hline $\begin{array}{l}\overline{\bar{a}} \\
\bar{\xi} \\
\overline{5}\end{array}$ & $\begin{array}{l}\bar{d} \\
\mathrm{~s}\end{array}$ & $\begin{array}{r}7.3 \\
1.20\end{array}$ & $\begin{array}{r}4.4 \\
0.89\end{array}$ & $\begin{array}{r}4.4 \\
0.92\end{array}$ & $\begin{array}{r}3.8 \\
0.87 \\
\end{array}$ & $\begin{array}{r}3.4 \\
0.58\end{array}$ & $\begin{array}{r}7.1 \\
0.83\end{array}$ & $\begin{array}{r}7.0 \\
0.76\end{array}$ & $\begin{array}{r}7.0 \\
0.75\end{array}$ & $\begin{array}{r}6.4 \\
0.73\end{array}$ & $\begin{array}{r}6.4 \\
0.74\end{array}$ & $\begin{array}{r}5.5 \\
0.58\end{array}$ & $\begin{array}{r}5.5 \\
0.82\end{array}$ \\
\hline$<\frac{m}{N}$ & $\begin{array}{r}7.3 \\
1.20\end{array}$ & * & 1.388 & 1.368 & 1.69 & 2.191 & 0.099 & 0.152 & 0.152 & 0.466 & 0.464 & 1.011 & 0.891 \\
\hline $\mathbb{m}^{\infty}$ & $\begin{array}{r}4.4 \\
0.89\end{array}$ & 0 & * & 0.000 & 0.341 & 0.680 & 1.570 & 1.576 & 1.585 & 1.235 & 1.227 & 0.745 & 0.634 \\
\hline א్̃ & $\begin{array}{r}4.4 \\
0.92\end{array}$ & 0 & 0 & * & 0.335 & 0.665 & 1.543 & 1.646 & 1.557 & 1.212 & 1.205 & 0.733 & 0.632 \\
\hline$\alpha_{0}^{ \pm}$ & $\begin{array}{r}3.8 \\
0.87\end{array}$ & 0 & 0 & 0 & * & 0.276 & 1.941 & 1.963 & 1.975 & 1.625 & 1.615 & 1.172 & 1.006 \\
\hline 땜 & $\begin{array}{r}3.4 \\
0 \quad 58 \\
\end{array}$ & 0 & 0 & 0 & 0 & * & 2.624 & 2.687 & 2.707 & 2.290 & 2.273 & 1.810 & 1.500 \\
\hline $\mathscr{c}_{0}^{\frac{\infty}{N}}$ & $\begin{array}{r}7.1 \\
0.83\end{array}$ & 0 & 0 & 0 & 0 & & * & 0.063 & 0.063 & 0.321 & 0.446 & 1.135 & 0.970 \\
\hline zঃ & $\begin{array}{r}7.0 \\
0.76\end{array}$ & 0 & 0 & 0 & 0 & & 0 & * & 0.000 & 0.403 & 0.400 & 1.119 & 0.949 \\
\hline $3^{\circ}$ & $\begin{array}{r}7.0 \\
0.75 \\
\end{array}$ & 0 & 0 & 0 & 0 & 0 & 0 & 0 & * & 0.405 & 0.403 & 1,128 & 0.955 \\
\hline 흔 & 0.73 & 0 & 0 & 0 & 0 & 0 & 0 & 0 & 0 & * & 0.000 & 0.687 & 0.581 \\
\hline$-\frac{m}{N}$ & $\begin{array}{l}6.4 \\
0.74\end{array}$ & 0 & 0 & 0 & 0 & 0 & 0 & 0 & 0 & 0 & * & 0.682 & 0.577 \\
\hline $0^{-\frac{D}{N}}$ & $\begin{array}{r}5.5 \\
0.58 \\
\end{array}$ & 0 & 0 & 0 & 0 & 0 & 0 & 0 & 0 & 0 & 0 & * & 0.000 \\
\hline ชุ̄̄ & $\begin{array}{r}5.5 \\
0.82\end{array}$ & 0 & 0 & 0 & 0 & 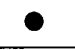 & 0 & 0 & 0 & 0 & 0 & 0 & * \\
\hline
\end{tabular}

$\overline{\mathrm{d}}$ : mean value of rib density

For others see reference of Table 15

Table 18. Frequency of two forms at three horizons (presence or absence of radial depression).

\begin{tabular}{|c|c|c|c|}
\hline Sample & $\begin{array}{c}\text { Type I } \\
\text { non-sulcate form }\end{array}$ & $\begin{array}{c}\text { Type II } \\
\text { sulcate form }\end{array}$ & total \\
\hline $\begin{array}{c}\text { Sample A } \\
\text { OR233 }\end{array}$ & $\mathrm{a}=11$ & $\mathrm{~b}=153$ & 164 \\
\hline $\begin{array}{c}\text { Sample B } \\
\text { OR234 }\end{array}$ & $\mathrm{c}=24$ & $\mathrm{~d}=99$ & 123 \\
\hline total & 35 & 252 & 287 \\
\hline \hline $\begin{array}{c}\text { Sample B } \\
\text { OR234 }\end{array}$ & $\mathrm{c}=24$ & $\mathrm{~d}=99$ & 123 \\
\hline $\begin{array}{c}\text { Sample C } \\
\text { OR242 }\end{array}$ & $\mathrm{e}=12$ & $\mathrm{f}=35$ & 47 \\
\hline total & 36 & 134 & 170 \\
\hline
\end{tabular}

мото, which can be infraspecifically distinguished from the typical form.

Sample OR233 is discriminated from others in the better development of a radial depression or nodulous protuberances. The typical form of Inoceramus hobetsensis NAGAO et MATSUMOTO could be probably group with it.

Sample OR218 is not discriminated from UN101B, and these two are distinguishable from others. This form is identical to Inoceramus teshioensis NAGAO et Matsumoto.

Samples UN101A, UF101, OI213 and 0I214 are not discriminated from one another and discriminated from others. The former group is referred to Inoceramus 
Table 19. Frequency of two forms at three horizons (presence or absence of nodulous protuberance).

\begin{tabular}{|c|c|c|c|}
\hline Sample & $\begin{array}{c}\text { Type I } \\
\text { non-nodulous form }\end{array}$ & $\begin{array}{c}\text { Type II } \\
\text { nodulous form }\end{array}$ & total \\
\hline $\begin{array}{c}\text { Sample A } \\
\text { OR233 }\end{array}$ & $\mathrm{a}=123$ & $\mathrm{~b}=41$ & 164 \\
\hline $\begin{array}{c}\text { Sample B } \\
\text { OR234 }\end{array}$ & $\mathrm{c}=116$ & $\mathrm{~d}=7$ & 123 \\
\hline total & 239 & 48 & 287 \\
\hline $\begin{array}{c}\text { Sample B } \\
\text { OR234 }\end{array}$ & $\mathrm{c}=116$ & $\mathrm{~d}=7$ & 123 \\
\hline $\begin{array}{c}\text { Sample C } \\
\text { OR242 }\end{array}$ & $\mathrm{e}=47$ & $\mathrm{f}=0$ & 47 \\
\hline total & 163 & 7 & 170 \\
\hline
\end{tabular}

Table 20. Data of approximate determination of infraspecific category.

\begin{tabular}{|c|c|c|c|c|c|c|c|c|c|c|c|c|}
\hline Samole & TA213A & TA213B & OR242 & OR234 & OR233 & QR218 & UN1O1A & UN101B & UF 101 & 01213 & Q1214 & AS201 \\
\hline$\frac{\text { character }}{\text { Sample }}$ & 123456 & 123456 & 123456 & 123456 & 123456 & 123456 & 123456 & 123456 & 123456 & 123456 & 123456 & 123456 \\
\hline TA213A & & $\bullet \bullet \bullet$ & $\bullet \bullet$ & $\bullet \bullet$ & $\bullet \bullet$ & $\bullet$ & $\bullet \bullet \bullet$ & - $\bullet$ & $\bullet \bullet \bullet$ & $\bullet \bullet \bullet$ & $\bullet \bullet$ & $\bullet \bullet \bullet$ \\
\hline TA213B & & $x$ & & & $\bullet$ & $\bullet \bullet$ & $\bullet$ & $\bullet \bullet$ & $\bullet$ & $\cdot$ & • & $\bullet$ \\
\hline QR242 & & & & & $\bullet$ & $\bullet \bullet$ & $\bullet$ & $\bullet$ & - & - & $\bullet$ & $\bullet$ \\
\hline OR234 & & & & & - & $\bullet \bullet$ & $\bullet$ & $\bullet \bullet$ & $\bullet$ & $\bullet$ & $\bullet$ & $\bullet$ \\
\hline QR233 & & & & & & $\bullet \bullet$ & $\bullet \bullet$ & $\bullet \bullet$ & $\bullet \bullet$ & $\bullet$ & $\bullet \bullet$ & $\bullet \bullet$ \\
\hline QR218 & & & & & & & $\bullet \bullet$ & & $\bullet$ & $\bullet$ & - & $\bullet$ \\
\hline UN101A & & & & & & & & $\bullet$ & & & & \\
\hline UN1O1B & & & & & & & & 7 & $\bullet \bullet$ & $\bullet$ & $\bullet$ & $\bullet$ \\
\hline \multicolumn{13}{|l|}{ UF101 } \\
\hline \multicolumn{13}{|l|}{01213} \\
\hline \multicolumn{13}{|l|}{01214} \\
\hline AS201 & & & & & & & & & & & & \\
\hline
\end{tabular}

solid circle: infraspecifically significant
1: simple ratio $\mathrm{L} / \mathrm{H}$
4: presence or absence of minor rings
2: beak angle
5: presence or absence of a radial depression
3: rib density
6: presence or absence of anterior wing

uwajimensis (YEHARA).

In the description of Inoceramus uwajimensis, NAGAO and MATSUMOTo gave a name var. yeharai to a form which has a wing-like area in the posterior part. The two forms are, however, commonly coexistent. As is shown in Table 21, the result of short-cut method indicated insignificant value in randam variable $\left(X^{2}\right)$ in all pairs of the samples. The fact implies that the two forms are hardly divided infraspecifically on either geographical or chronological viewpoint. It is more reasonable to deal with the form with posterior wing-like area as a mere variety of the species as before.

Sample OI214 is divided into two groups in the present examination through 
Table 21. Evaluation of significancy by short-cut method in pairs selected samples.

(presence or absence of wing-like area)

\begin{tabular}{|c|c|c|c|c|}
\hline Population & Type I & Type II & total & $\begin{array}{c}X^{2} \\
\text { significancy }\end{array}$ \\
\hline OI214A & $a=9$ & $\mathrm{~b}=20$ & 29 & \multirow{3}{*}{$\begin{array}{c}0.538 \\
\text { not sig. }\end{array}$} \\
\hline OI213 & $c=13$ & $\mathrm{~d}=42$ & 55 & \\
\hline total & 22 & 62 & 84 & \\
\hline OI213 & $c=13$ & $\mathrm{~d}=42$ & 55 & \multirow{3}{*}{$\begin{array}{c}0.007 \\
\text { not sig. }\end{array}$} \\
\hline UF101 & $e=10$ & $\mathbf{f}=31$ & 41 & \\
\hline total & 23 & 73 & 96 & \\
\hline UF101 & $e=10$ & $f=31$ & 41 & \multirow{3}{*}{$\begin{array}{c}0.685 \\
\text { not sig. }\end{array}$} \\
\hline UN101A & $g=10$ & $h=20$ & 30 & \\
\hline total & 20 & 51 & 71 & \\
\hline OI214A & $a=9$ & $b=20$ & 29 & \multirow{3}{*}{$\begin{array}{c}0.379 \\
\text { not sig. }\end{array}$} \\
\hline UF101 & $e=10$ & $f=31$ & 41 & \\
\hline total & 19 & 51 & 70 & \\
\hline OI214A & $\mathbf{a}=\mathbf{9}$ & $\mathrm{b}=\mathbf{2 0}$ & 29 & \multirow{3}{*}{$\begin{array}{c}0.036 \\
\text { not sig. }\end{array}$} \\
\hline UN101A & $g=10$ & $h=20$ & 30 & \\
\hline total & 19 & 40 & 59 & \\
\hline OI213 & $c=13$ & $\mathrm{~d}=42$ & 55 & \multirow{3}{*}{$\begin{array}{c}0.611 \\
\text { not sig. }\end{array}$} \\
\hline UN101A & $g=10$ & $\mathrm{~h}=20$ & 30 & \\
\hline total & 23 & 62 & 85 & \\
\hline
\end{tabular}

Type I : form with posterior wing-like area

Type II: form without posterior wing-like area

chi-square test and Student's $t$-test. As the sympatric subspecies is, however, unreasonable, they could be regarded as the same species. As another alternative, they could be regarded as two species of different stock. We need more lines of evidence from various areas to settle the problem.

\section{Descriptions of Species}

The species of Inoceramus from the Upper Cretaceous of Japan were classified primarily on the ground of typological concept (e.g. YeHARA, 1924; NAGAO and Matsumoto, 1939-40; Matsumoto, 1957; Matsumoto and Noda, 1968). Although these authors attempted to describe the variation of a species to some extent, they recognized the variation on the basis of the observation of individual specimens from scattered localities of partly synchronous and partly heterchronous beds.

In the present study certain morphological characters have been biometrically 
and statistically examined on samples of a considerable size collected from well ordered sequences. The results are here taken into consideration for the revised descriptions of species. However, as is mentioned above (p. 212), the samples do not satisfactorily represent the populations. In this respect the present description can be regarded as provisional memoranda based mainly on the examined samples from Southwest Japan, which do not cover the entire framework of a species in space and time. For the information on the specimens of Hokkaido, Sakhalin and other oversea areas I owe much on Professor MaTSUMOTo's comprehensive knowledge.

\section{Inoceramus teraokai MATSUMoTo et NoDA}

Pl. 32, Figs. 1-5, 9; Text-fig. 15A

1968. Inoceramus teraokai Matsumoto et NodA, Trans. Proc. Palaeont. Soc. Japan, [N. S.], (71), p. 319, pl. 32, figs. 1-5, text-fig. 2.

Holotype.-GK .H6833, from Loc. TA204, upper part of the Tano Formation, Onogawa basin, Kyushu, as originally designated.

Morphologic characters.-Shell of moderate size, about 60 to $80 \mathrm{~mm}$ in $\mathrm{H}$, equivalve, less convex, highly inequilateral, obliquely elongated from the back to the postero-ventral margin. The axis of growth gently convex anteriorly; obliquity gradually increased with growth, showing $70^{\circ}$ to $50^{\circ}$ in $\beta$. Hinge-line of moderate length, about two-fifth of 1 . Umbo subterminal and improminent, rising slightly above the hinge-line. Gently inflated main part of the valve gradually flattened to posterior wing-like area; anterior part fairly steep and provided with small but distinct anterior ear. Anterior margin broadly arcuate, passing gradually to gently curved ventral one; postero-ventral margin narrowly rounded, continuing to nearly straight long posterior one.

Surface ornamented with low and round-topped major concentric ribs, which are regular in strength and distance in the main part but may become irregular

\section{Explanation of Plate 32}

(All figures natural size)

Figs. 1-5. Inoceramus teraokai Matsumoto et NoDA .................. 248

1. GK. H6833, Holotype, inner cast of right valve. Loc. TA204, a mountain path-side from Yamaji to Otomi, Usuki City, Oita Pref. Lower part of Upper member of Tano Formation (coll. Y. TERAOKA).

2. GK. H6836, Paratype, rubber cast of left external mould. Loc. TA209, a western slope of hill occupying northern area of Tarabaru, Notsu Town, Ono County, Oita Pref. Probably the same horizon as TA213 (coll. M. NODA).

3. JG. H2123, inner cast of right valve. Loc. TA213 (coll. M. NodA).

4. JG. H2125, left valve. Loc. TA213 (coll. A. KAI).

5. JG. H2126, inner cast of left valve. Loc. TA213 (coll. M. NodA).

Figs. 6-9. Inoceramus hobetsensis NAGAo et MATSUмото ............ Page 249

6. JG. H2307, closed valves. Loc. OR242 (coll. M. NODA).

7. JM. 206, inner cast of right valve. Loc. OR234 (coll. O. MitsuKUDE).

8. TO. 205, inner cast of left valve. Loc. OR234 (coll. S. ToTOKI).

9. Associated with Inoceramus teraokai. JG. H2016, inner cast of left valve. Loc. TA213 (coll. M. NODA). 

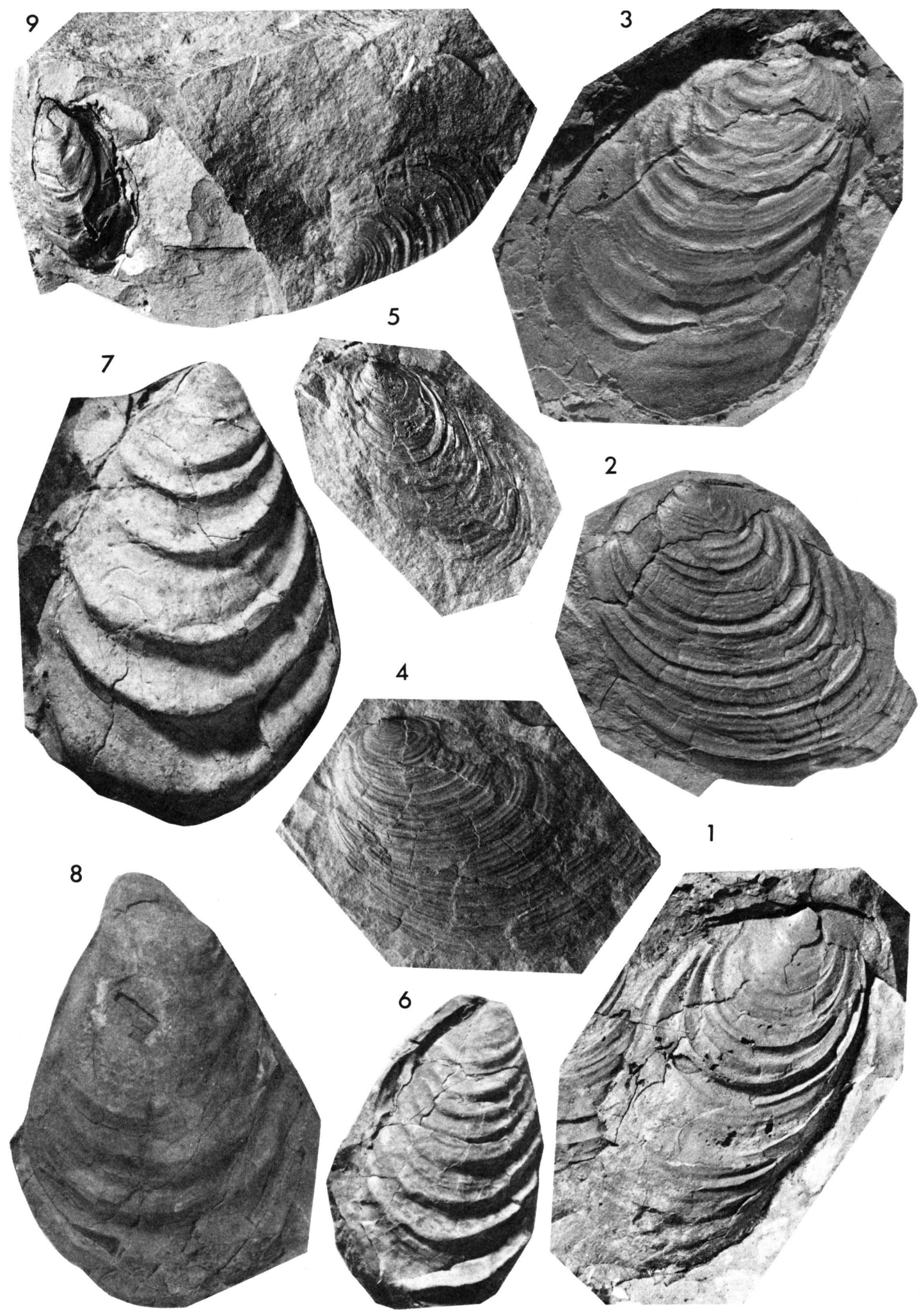

M. NoDA: Succession of Inoceramus in Upper Cretaceous 

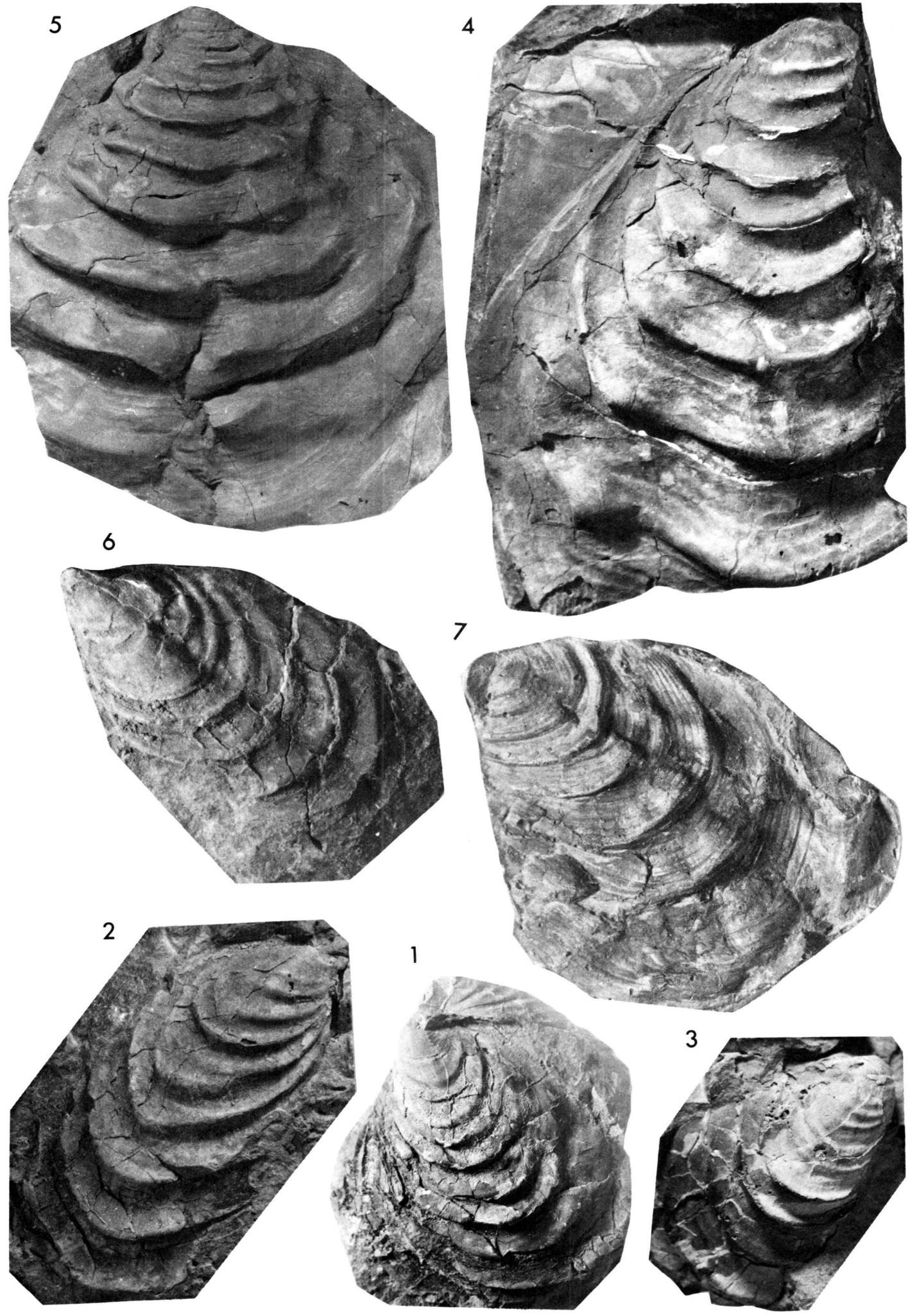

M. NoDA: Succession of Inoceramus in Upper Cretaceous 
in the late stage of growth. Numerous fine minor concentric rings discernible on the ribs and the interspaces.

Remarks.-Specimens of Sample TA213A are assigned to this species. As MATSUMOTо and NODA (1975) discussed, the present species is intimately related to Inoceramus labiatus (SchLot HEIM).

Occurrence.-Extent of geographical distribution is not yet precisely known. Common in the shaly part of the Upper member of the Tano Formation, southern wing of the Onogawa Group, Oita Prefecture, where this species occurs together with Inoceramus hobetsensis NAGAO et MATSUMOTO and Subprionocyclus neptuni (GeINITZ), Middle Turonian.

Inoceramus hobetsensis Nagao et Matsumoto Pl. 32, Figs. 6-9; Pl. 33, Figs. 1-7; Pl. 34, Figs. 1-5;

P1. 35, Fig. 1; Text-figs. 16, 20.

1924. Inoceramus uwajimensis YeHARA (pars). Japan. Jour. Geol. Geogr., 3, p. 36 , pl. 4, figs. 1,2 (only).

1925. Inoceramus cf. percostatus, YABE and NAGAO. Sci. Rept. Tohoku Imp. Univ. [2], 7, (4), p. 115, pl. 28, figs. 7, 8; pl. 28, fig. 10.

1939. Inoceramus hobetsensis NAGAo et MATSUmoto. Jour. Fac. Sci., Hokkaido Imp. Univ. [4], 4, (3-4), p. 281, pl. 28, fig. 3; pl. 29, figs. 1-6; pl. 30, figs. 2, 3.

1939. Inoceramus hobetsensis var. nonsulcatus NAGAo et MATSUMoto, Ibid., p. 282 , pl. 27 , fig. 3 ; pl. 28 , fig. 4 ; pl. 30 , fig. 1 .

Types.-NAGAO and MATSUMOTo (1939) established this species on a number of syntypes. Probably because of a considerable extent of variation, they refrained from designating a single holotype. To avoid nomenclatorial confusion that might arise in the future I designate here the specimen figured by NAGAO and MATSUмото, 1939, pl. 29, fig. 3 (Hokkaido University Collection) as the lectotype. It is of huge size and has a well marked radial sulcus. It came from the Hobetsu area, central Hokkaido. It was illustrated by NAGAO (1935) in a report written in

\section{Explanation of Plate 33}

(Figures natural size, unless otherwise stated)

Figs. 1-7. Inoceramus hobetsensis NAGAo et Matsumoto ............Page 249

1. Form with weak radial depression, GK. H6941, articulate valves. Loc. OR234 (coll. K. MrYAZAKI).

2. Form with weak radial depression, MK027, inner cast of right valve. Loc. OR234 (coll. H. YамAMOTO).

3. Form without radial depression, JG. H2020, articulate valves. Loc. OR234 (coll. M. NODA).

4. Nodulous form, JG. H2030, inner cast of right valve. $\times 0.8$. Loc. OR234 (coll. M. NoDA).

5. Typical form. JG. H2025, inner cast of left valve. $\times 0.4$, Loc. OR233 (coll. Н. ҮАмАмото).

6. Typical form. MK206, inner cast of left valve. Loc. OR233 (coll. H. YAMAмото).

7. Nodulous form in which the nodes appear in early stage of growth, foretelling the characters of Inoc. iburiensis NAGAo et MATSUMoro from the Upper Turonian in Hokkaido. JG. H2017, plaster cast of left external mould. Loc. OR233 (coll. M. NODA). 
Japanese under this specific name (nom. nud.) without diagnosis.

Morphological characters.-Shell of moderate to large size (e.g. 60-160 mm in $\mathrm{H}$ ) in many specimens, attaining a huge size ( 400 to $850 \mathrm{~mm}$ in $\mathrm{H}$ ) in some others, somewhat inequivalve, moderately convex from anterior to posterior and also along the growth axis, umbonal region considerably inflated, anterior part steep or truncated, posterior part gradually flattened, passing to wing-like area. Umbo terminal; left umbo somewhat incurved and more prominently projected beyond the hinge-line. Beak angle acute. Obliquity not conspicuous $\left(\delta=70^{\circ}\right)$, gradually decreasing with growth. Outline much high, elongate pentagonal or suboval in general aspect; antero-dorsal margin nearly straight or rather concave, anterior margin broadly convex, gradually passing to moderately rounded ventral and then postero-ventral margins, posterior one broadly arcuate and postero-dorsal margin very gently convex or almost straight, forming obtuse angle with the hinge-line of moderate length (about 2/3 l).

Surface ornamented with coarse and strong concentric ribs which are rounded on top and separated by somewhat wider interspaces with concave bottom. Transverse section of ribs asymmetric, with moderate inclination to the umbo and steep one to the venter. Numerous concentric rings well marked, which are as a rule parallel to the curvature of the major ribs but may be oblique in some specimens. In many groups of specimens, including the lectotype from Hokkaido, a radial depression or furrow runs somewhat posteriorly along the growth-axis. In some other specimens the furrow does not appear, whereas in still other specimens even the nodulous protuberlances are developed on either side of the distinct furrow.

Remarks.-Samples TA213B, OR242, OR234 and OR233 are referred to Inoceramus hobetsensis.

So far as the material of the Onogawa Group is concerned, the statistical analyses of the successive samples have revealed the following facts. (1) Sample TA213 of the available lower horizon contains predominantly nonsulcate specimens and some weakly sulcate ones. (2) Sample OR242 of the next higher horizon contains a considerable number of non-sulcate specimens but sulcate specimens become somewhat more numerous than in TA213B. (3) The simple ratio $\mathrm{L} / \mathrm{H}$ and the beak angle of Sample OR242 are on the average somewhat larger than those of Sample TA213B. (4) Sample OR234 contains relatively more numerous specimens of the sulcate form, but still the non-sulcate form is somewhat predominant. Some examples of the latter are illustrated (e. g. JM. 206, Pl. 32, Fig. 7 and OT. 205, Pl. 32, Fig. 8). It is noted that a form with nodulous protuberance appears in this sample (e. g. JG. H2030, Pl. 33, Fig. 4), although it is only represented by a small number of specimens. In general Sample OR234 contains fairly large individuals, from $160 \mathrm{~mm}$ to $200 \mathrm{~mm}$ in $\mathrm{H}$. The abrupt change of rib density from high to low is common in these large specimens. (5) Sample OR233 mainly consists of the specimens with a well marked furrow. If we apply the short-cut method, Sample OR233 is distinct from Samples GR234 and other underlying ones in this respect. It contains huge individuals, from $440 \mathrm{~mm}$ to $850 \mathrm{~mm}$ in $\mathrm{H}$. The "broad form" (with larger ratio of $\mathrm{L} / \mathrm{H}$ ) increases in number. In most individuals the minor rings are parallel to the curvature of the major ribs in the preceding samples from lower horizons, but in some of this sample the minor rings run somewhat obliquely across the major ribs (e. g. GK. H6945, NoDA, 1971, pl. 1, fig. 7). Sometimes the major ribs do not persist from anterior to posterior but a rib on the anterior half may continue to an interspace of the ribs on the 
posterior half (e. g. JG. H2009, Pl. 34, Fig. 2) or the ribs may be irregular in intensity, distance and persistency (e. g. JG. H2020, Pl. 34, Fig. 5). (6) In Sample OR233 the specimens with nodulous protuberance are relatively more numerous than in OR234; the nodes appearing at an earlier growth stage (e. g. JG. H2017, Pl. 33, Fig. 7). The nodulous individuals are commonly elongated along the growthaxis, with smaller $\mathrm{L} / \mathrm{H}$ and have considerably inflated valves. Specimens from Loc. OR230 of still higher horizon are characterized by the considerable number of nodulous forms although they are inadequately deformed for biometric examination.

The form without radial furrow was called Inoceramus hobetsensis var. nonsulcatus by NAGAO and MATSUmoto (1939). They showed several examples from Hokkaido, but the detailed examination of samples from horizon to horizon or from place to place was not carried out in that date. The above described facts in the Onogawa Group seem to enable us to subdivide infraspecifically the group of Samples TA213B through OR234 below from that of Samples OR233 above. Although I am tempted to call the former group Inoceramus hobetsensis nonsulcatus, I refrain from doing so until the material from Hokkaido be examined more precisely with a result adequately compared with that of Southwest Japan. Similarly a group with nodulous protuberance can be distinguished, but I would not give a name and a definition of the intraspecific taxon at this moment.

Distribution and occurrence.-For the location, stratigraphic position and mode of occurrence of the specimens at Locs. TA213, OR242, OR234 and OR233 (see p. 220, 221). In addition there is OR230 which is situated about $70 \mathrm{~m}$ stratigraphically above OR233 in the Onogawa Group.

According to MATSUMOTO (1959 and recent personal information) I. hobetsensis is widespread and occurs in abundance in the main or middle part of the Turonian in Hokkaido and southern Sakhalin and some comparable specimens are also found from North America. Collignoniceras woolgari (MANTELL) sometimes occurs in the middle part of the Zone of Inoceramus hobetsensis of Hokkaido.

Affinities.-The above mentioned nodulous form closely resembles Inoceramus iburiensis NAGAO et MATSUMOTO, from the upper part of the Turonian in Hokkaido, but differs in less convexity of the valves. The nodulous form from the Onogawa Group should be specifically included in $I$. hobetsensis by the fact that there are various grades of intermediate forms even in one sample. Only the infraspecific subdivision is suggested. It may be stated that the nodulous form foretells the characters of $I$. iburiensis. To know the true relationship we should further examine the material from Hokkaido and other areas.

Inoceramus percostatus MÜLlER (1888) (see also HEINE, 1929), from the Upper Turonian and the Lower Emscher (approximately Coniacian) of Germany, closely resembles the above nodulous form. Furthermore, Inoceramus gibbosus SCHLÜTER is probably a succeeding species in which the nodes become more prominent. As these species are geographically much apart from the Japanese ones and of somewhat different ages, there is much to be done to know exactly the relationships between the species from Germany and Japan.

\section{Inoceramus teshioensis NAGAO et MATSUMOTO}

Pl. 35, Figs. 2-7; Text-fig. 15B

1939. Inoceramus teshioensis Nagao et Matsumoto, Jour. Fac. Sci., Hokkaido Imp. Univ., [4], 4, p. 274, pl. 24, figs. 6, 7, 9; pl. 26, figs. 5, 6, 7. 
Types.-NAGAO and MATSUMOTO established this species on several syntypes. In the typological viewpoint I-711 of the University of Tokyo (NAGAO and MATSUмото, 1939, pl. 24, fig. 7-misspelled as T-721 in the explanation of plate), from the Abeshinai area, Teshio province, Hokkaido, is here designated as the lectotype.

Morphological characters.-Shell small or of moderate size, subequivalve, somewhat inequilateral, slightly higher than long, moderately convex along the axis of growth and also from anterior to posterior; anterior part steep or nearly perpendicular to the valve plane; posterior part gradually flattened, passing to wing-like area. Obliquity less conspicuous and constant throughout growth. Antero-dorsal margin straight or slightly concave; anterior margin rounded, gradually passing to arcuate ventral and postero-ventral ones; posterior margin broadly curved, forming an obtuse angle with the hinge-line. Hinge-line of moderate length, nearly as long as or slightly longer than a half of the shell length $(1 / 21)$. Umbo subterminal; that of the left valve considerably curved inward and moderately forward.

Surface ornamented with rather low concentric ribs which are regular in intensity and distance, separated by wider interspaces; concentric rings combined with the major ribbing.

Remarks.-Specimens of Sample OR218 represent Inoc. teshioensis in the Onogawa Group. Those of Sample UN101B are also similar to them.

Distribution and occurrence.-According to MATsumoto (1959, elsewhere) I. teshioensis is common in the Upper Turonian of Hokkaido, occurring in muddy sediments and also in somewhat sandy siltstone or silty sandstone. Various kinds of ammonites are embedded in the same sediments. Subprionocyclus bravarisianus (D'ORBIGNY), S. normalis (ANDERSON) and then Reesidites minimus (HAYASAKA et FUKUDA) are the important subzonal indices in the zone of Inoceramus teshioensis of Hokkaido. See p. 221 for the mode of occurrence at Loc. OR218 in the Onogawa Group. If the specimens of UN101B were really of identical species with those of OR218, Inoc. teshioensis would become to range up to lower Lower Coniacian, but the evidence is not convincing.

Affinity.-As is examined in the foregoing pages, the morphological difference is distinct between Sample OR218 and the underlying Sample OR233. This probably means that $I$. teshioensis has no affinity with $I$. hobetsensis, belonging pos-

\section{Explanation of Plate 34}

(Figures natural size, unless otherwise stated)

Figs. 1-5. Inoceramus hobetsensis Nagao et Matsumoto .......... Page 249

1. Broad form with weak radial depression. JG. H2011, inner cast of right valve. Loc. OR233 (coll. M. NodA).

2. Form with irregular ornament of which the concentric ribs of anterior half of flank correspond to the interspaces of posterior half. JG. H2009, inner cast of right valve. Loc. OR233 (coll. M. NoDA).

3. Nodulous form. JG. H2028, plaster cast of left external mould. $\times 0.6$. Loc. OR233 (coll. H. YамAMOTO).

4. Broad form. JG. H2021, inner cast of left valve. $\times 0.8$. Loc. OR233 (coll. M. NODA).

5. Form with irregular ornament of which the concentric ribs are very irregular in strength and distance and not persistent from anterior to posterior. JG. H2022, inner cast of left valve. Loc. OR233 (coll. M. NODA). 

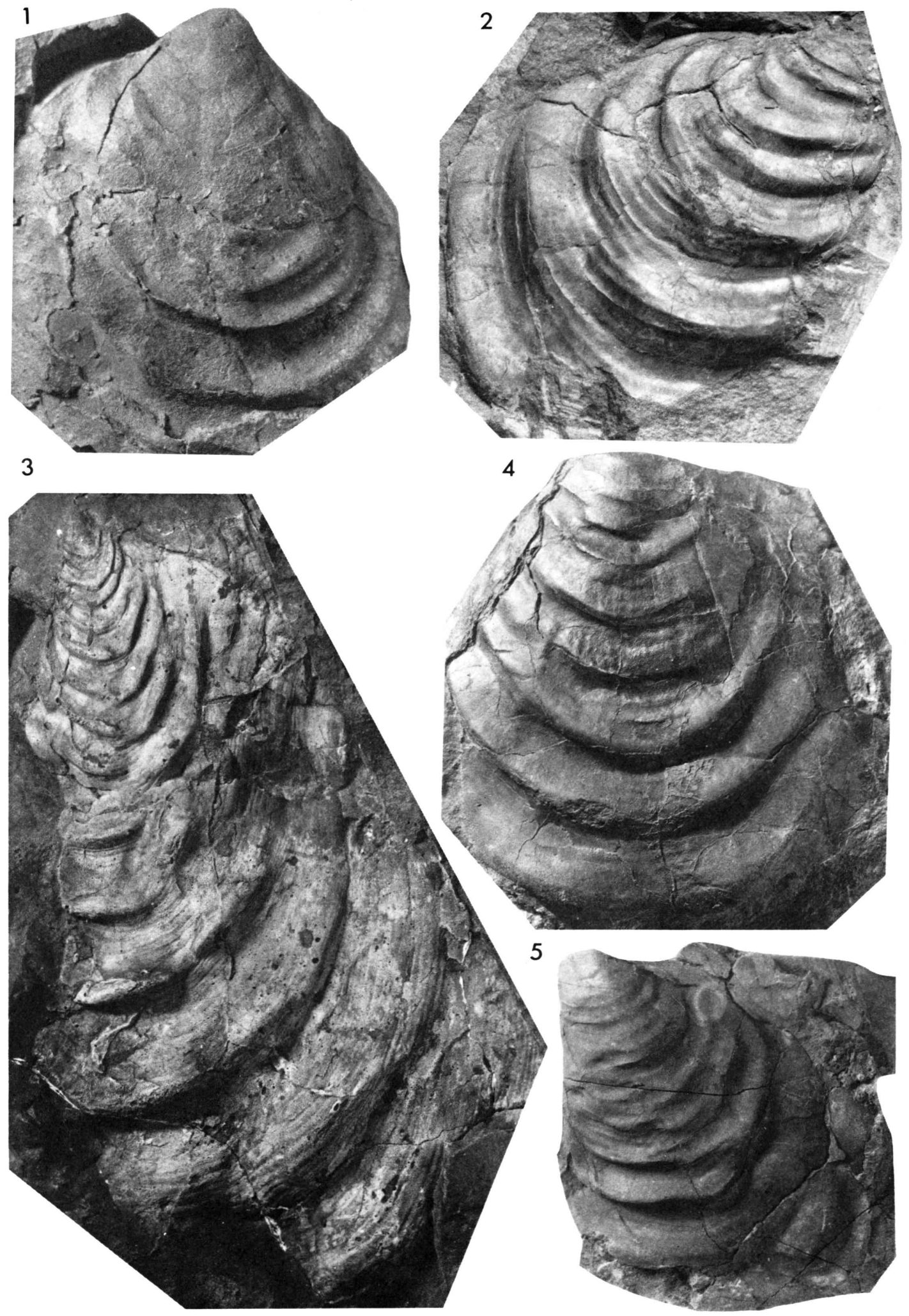

M. NoDA: Succession of Inoceramus in Upper Cretaceous 
M. NoDA: Succession of Inoceramus in Upper Cretaceous

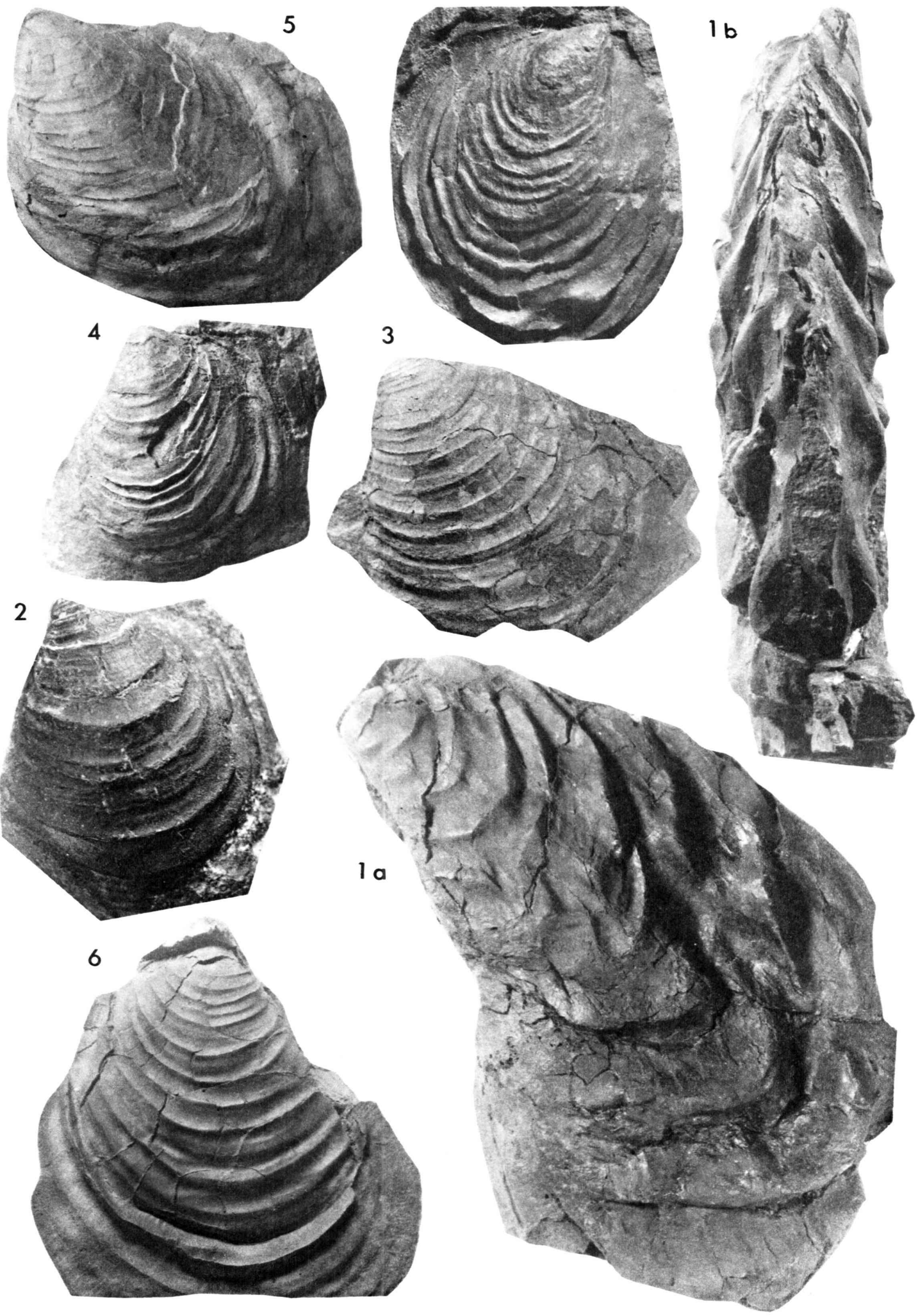

M. NoDA: Succession of Inoceramus in Upper Cretaceous 
sibly another lineage.

There is a specimen, GK. H6949 (Pl. 35, Fig. 2), from Loc. OR229, immediately below OR218, which has stronger and coarser ribs than normal specimens of I. teshioensis. In other characters there is no distinction.

MATSUMOTо (1959, p. 84) noted a resemblance between certain form of $I$. teshioensis and I. costellatus WooDs, from the Upper Turonian Chalk Rock of England.

\section{Inoceramus uwajimensis (YEHARA)}

Pl. 36, Figs. 1-8; Text-fig. 17

1924. Inoceramus uwajimensis YeHARA, Japan. Jour. Geol. Geogr., 3, p. 36, pl. 3, figs. 1,2 ; pl. 4, fig. 2.

1939. Inoceramus uwajimensis, NAGAO and MATsumoto, Jour. Fac. Sci., Hokkaido Imp. Univ., [4], 4, (3-4), p. 286, pl. 34, figs. 1, 3, 4, 6; pl. 35, figs. 1-3.

1939. Inoceramus uwajimensis var. yeharai NAGAo et MATSUmoto, Ibid., [4], 4 (3-4), p. 287, pl. 34, figs. 2,5 ; pl. 35, fig. 4 .

Lectotype.-The specimen figured by YehaRA (1924), pl. 3, fig. 2, from Furushiroyama, Uwajima Group, designated by Matsumoto in TAKaI and Matsumoto, 1961, p. 273.

Morphological characters. - Shell of moderate size on the average, ranging to a considerable extent $(50-200 \mathrm{~mm}$ in $\mathrm{H})$, equivalve, moderately convex and nearly symmetric in the antero-posterior transverse section, typically oval but sometimes subpentagonal in outline, higher than long and elongated along the growth axis, which is straight or gently concave anteriorly, showing little obliquity. Antero-dorsal margin straight or slightly concave, passing gradually to broadly arched anterior one; ventral margin narrowly rounded with a subsymmetrical curvature; posterior margin broadly arched. Postero-dorsal wing-like area is normally absent but present in some specimens. Umbo subterminal, slightly curved forward and inward, slightly projecting beyond the short hinge-line.

Surface ornamented with low, sharp-topped concentric ribs, which are normally regular in strength and distance and separated by wider, gently concave

\section{Explanation of Plate 35}

(Figures all natural size)

Fig 1. Inoceramus hobetsensis Nagao et Matsumoto . . . . . . . . . Page 249 Nodulous form. a: lateral view; b: posterior view. JG. H2001, closed valves. Loc. OR233 (coll. H. YAMAMOTO).

Figs. 2-7. Inoceramus teshioensis Nagao et Matsumoto ........... Page 251

2. Form with strong concentric ribs. GK. H6949, inner cast of left valve. Loc. OR229, a left bank about $1000 \mathrm{~m}$ downstream from Wada, Asaji Town, Ono County, Oita Pref. Middle part of Upper member of Ryozen Formation, Onogawa Group (coll. T. KAMEYAMA).

3. Crushed secondarily. GK. H6948, left valve. Loc. OR218 (coll. M. NoDA).

4. GK. H6947, inner cast of left valve. Loc. OR218 (coll. M. NoDA).

5. Form with weak concentric ornament. JG. H2238, left valve. Loc. OR218 (coll. M. NoDA).

6. Crushed secondarily. JG. H2239, closed valves. Loc. OR218 (coll. M. NodA).

7. JG. H2240, right valve. Loc. OR218 (coll. M. NodA). 
interspaces without perceptible concentric rings. Only on the umbonal part fine concentric rings are discernible.

Remarks.-Specimens of Samples UN101A and UF101 of the Uwajima Group, those of Samples OI213 and OI214A of the Onogawa Group and those of Sample AS201 of the Futaba Group are all referred to the present species. In every sample the form with a posterior wing is coexistent with the normal form without the wing. The former was called Inoc. uwajimensis var. yeharai by NAGAO and MATSUMоTо, but this name would have proved unnecessary in the population concept. The functional meaning of the posterior wing-like area should be worked out.

The analyses of the Samples UN101A, UF101, OI213 and OI214 from the Coniacian sequences show that the shell-form chronologically changes in various trends. In other words the extent of variation in shell-form becomes greater as the sequence goes upward. Whether this is maintained in the material of Hokkaido and elsewhere or not is another question.

Distribution and mode of occurrence.-According to Matsumoto (1959, p. 85; also personal information) Inoceramus uwajimensis is a widespread index of Lower Urakawan (approximately Coniacian) throughout the Japanese islands and extends further to Sakhalin, Kamchatska, Alaska and California.

For the mode of occurrence at the above mentioned sample localities see the description in p. 222, 223. According to MATsumoto, in Hokkaido and South Sakhalin this species occurs abundantly sometimes almost exclusively, in particular beds. The sediments are in many cases mudstone and fine-sandy siltstone, but in some cases sandstone and even conglomerate. Ammonites are found occasionally from the beds containing I. uwajimensis. Baculites yokoyamai TokunAGA et SHIMIZU, Scalarites sp., Scaphites sp., Otoscaphites sp., Forresteria (Forresteria) allaudi (Boule, Lemoine et Thevenin), Yabeiceras orientale Tokunaga et Shimizu etc. are important among many others. Some of them undoubtedly indicate Conician. Didymotis akamatsui (YEHARA) is another commonly associated bivalve species.

Affinities.-The results of the present analyses show that there is probably no relation between Upper Turonian I. teshioensis and Lower Coniacian I. uwajimensis. A possibility of the derivation of I. uwajimensis from certain populations of $I$. hobetsensis could be suggested, but the available evidence is by no means sufficient.

In Samples OI213 and AS201 of high variability the extreme forms apparently looked like a different species, i.e. Inoceramus mihoensis MATSUMoTo, if the presence of intermediate forms were ignored. At still higher horizon OI214 the sample consists of two groups without intermediate forms. One of them OI214B could be ascribed to $I$. mihoensis for the morphological resemblance. MATSUMOTO (1957) is of opinion that I. mihoensis is an offshoot from the main stock of the group of $I$. inconstans WooDs. It is, therefore, open to question whether a serial evolutionary relation existed from I. uwajimensis to I. mihoensis or they are of idependent stocks. In the latter case what I called the intermediate forms in Samples OI213 and AS201 would be apparent. The question should be answered by further examination of the materials from Northeast Japan, Hokkaido and other areas.

It should be recalled that $I$. deformis MEek, from the Coniacian of the Western Interior province of North America, is also allied to I. mihoensis and I. inconstans, as pointed out by Matsumoto $(1957$, p. 86). Matsumoto $(1959$, p. 85) has noted 


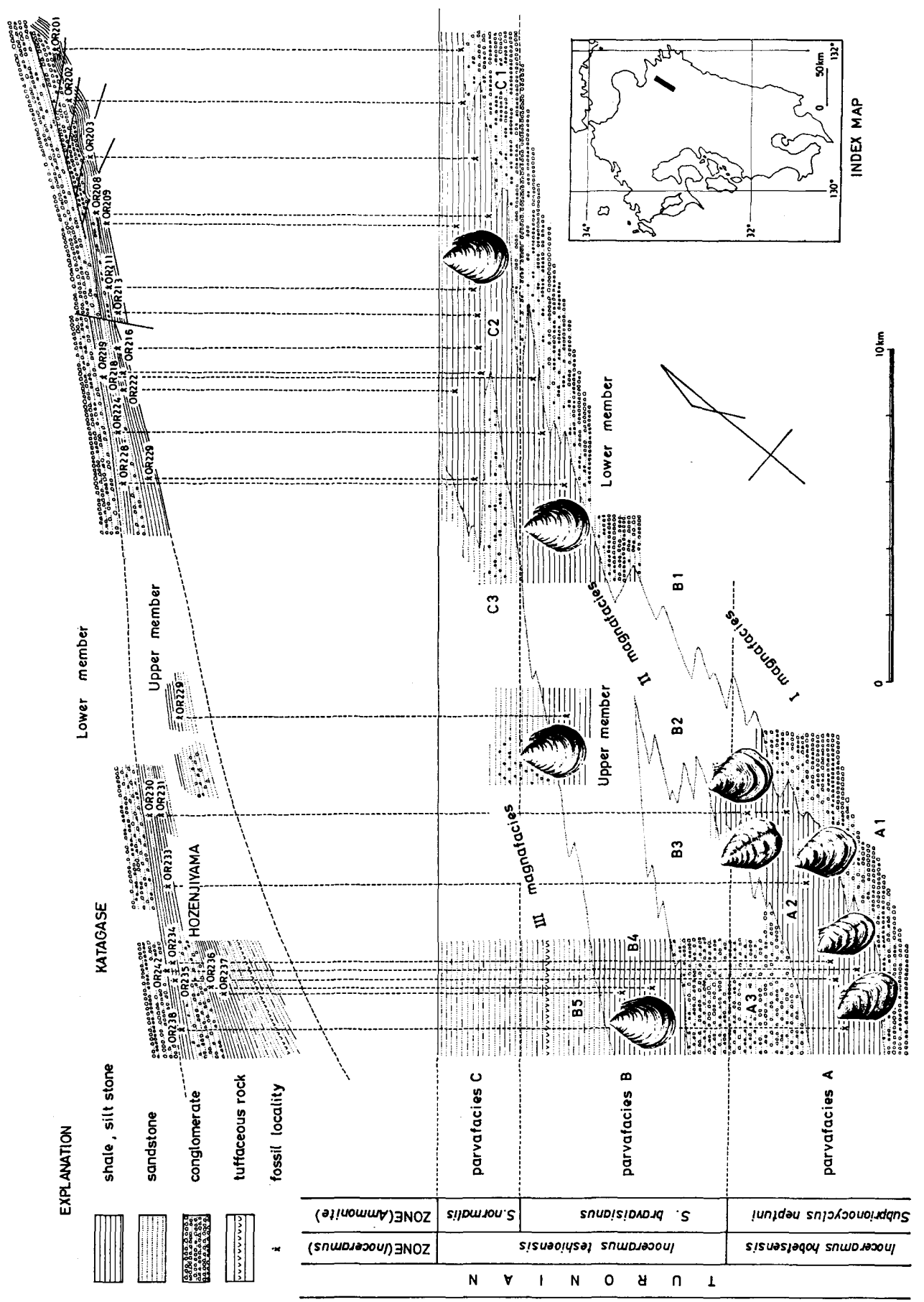

Fig. 21. A diagram showing the diachronous relation of rock units in the Upper member of the Ryozen Formation, Onogawa Group: above-geographical distribution of fossil localities; below-stratigraphical position of the localities and chronological change of Inoceramus. 
that I. uwajimensis is allied to I. kleini MÜLLER, from the Emscher of Germany, and also to I. stantoni Sokolow [=I. acuteplicatus STANTON], from the Coniacian of North America. Taking these points into consideration, we may need further examination with the internation cooperation.

\section{Further Remarks}

Through this study I have noticed several facts which may be concerned with the relation between the morphological change of Inoceramus and the environmental change. Paleoenvironments should be inferred on the basis of various kinds of information, but I take here mainly the facts in lithofacies.

1. The morphological relations of Sample TA213A, OR242, OR234, OR233 and OR230, as revealed by the foregoing analyses, seems to suggest that Inoceramus hobetsensis may have evolved along the trends of certain chronoclines, such as general broadening in outline, enlargement in size, gradual development of a radial furrow and appearance and strengthening of nodulous protuberance on either side of the radial furrow. Aside from TA213A, all the specimens of the above samples (and also Sample OR218 of Inoceramus toshioensis) were obtained from the exclusively shaly deposits of the Upper member of the Ryozen Formation, Onogawa Group. The succession of samples which may represent stages of phylogenetic series in the lineage of $I$. hobetsensis and appearance of another species I. teshioensis, together with the successive change in the associated ammonites, indicate a diachronous relation between parvafacies and magnafacies. As is schematically shown in Fig. 21, the fossil localities are all allocated in the shaly litho-facies. This implies that the environment under which Inoceramus lived and the Inoceramus bearing muddy sediments deposited shifted with time from southwest to northeast in the Onogawa basin.

2. As is interpreted from the mode of occurrence of the specimens, the examined species were probably benthic. Their mode of life, therefore, may have been considerably affected by the nature of substratum. The fact that the mor-

\section{Explanation of Plate 36}

(Figures all natural size)

Figs. 1-8. Inoceramus uwajimensis (YEHARA) ........................ 253

1. Elongate form with posterior wing-like area. JG. H2070, left valve. Loc. OI213 (coll. M. NODA).

2. Elongate form without posterior wing-like area. MK016, inner cast of left valve. Loc. OI213 (coll. H. YAMAMOTO).

3. Form with large beak angle and with weak concentric ornament. JG. H2102, inner cast of right valve. Loc. OI214 (coll. M. NODA).

4. Form with radial pseudosclupture on interspaces of concentric ribs. MK026, inner cast of right valve. Loc. OI213 (coll. H. YAMAMOTo).

5. Elongate form with narrow posterior wing-like area. JG. H2068, inner cast of right valve. Loc. OI213 (coll. M. NODA).

6. Form with large beak angle and with weak concentric ribs. JG. H2066, inner cast of left valve. Loc. OI213 (coll. M. NODA).

7. JG. H2053, inner cast of left valve. Loc. OI213 (coll. M. NoDA).

8. Form with weak ornament. JG. H2071, closed valves. Loc. OI213 (coll. SAT0). 

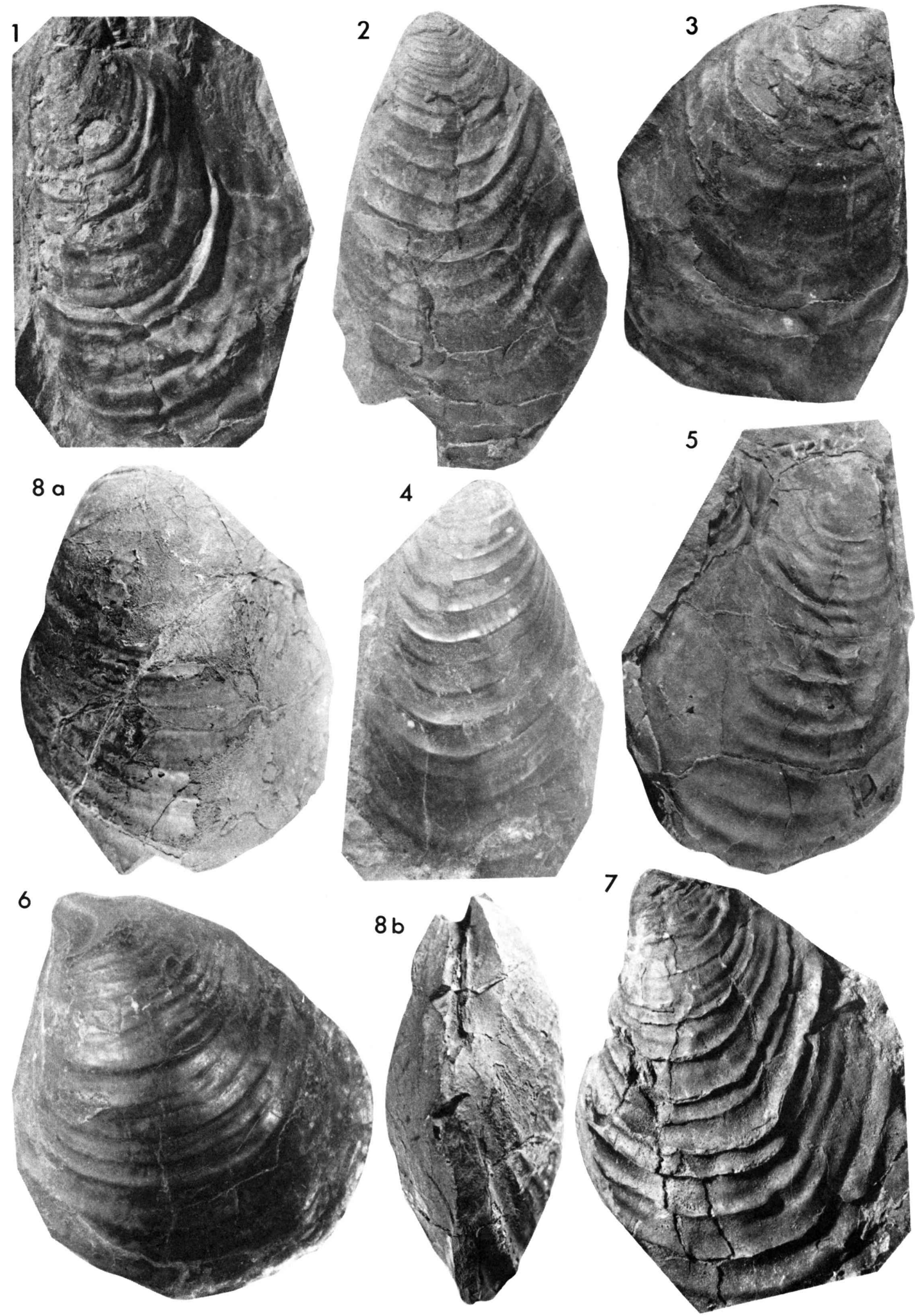

M. NoDA: Succession of Inoceramus in Upper Cretaceous 

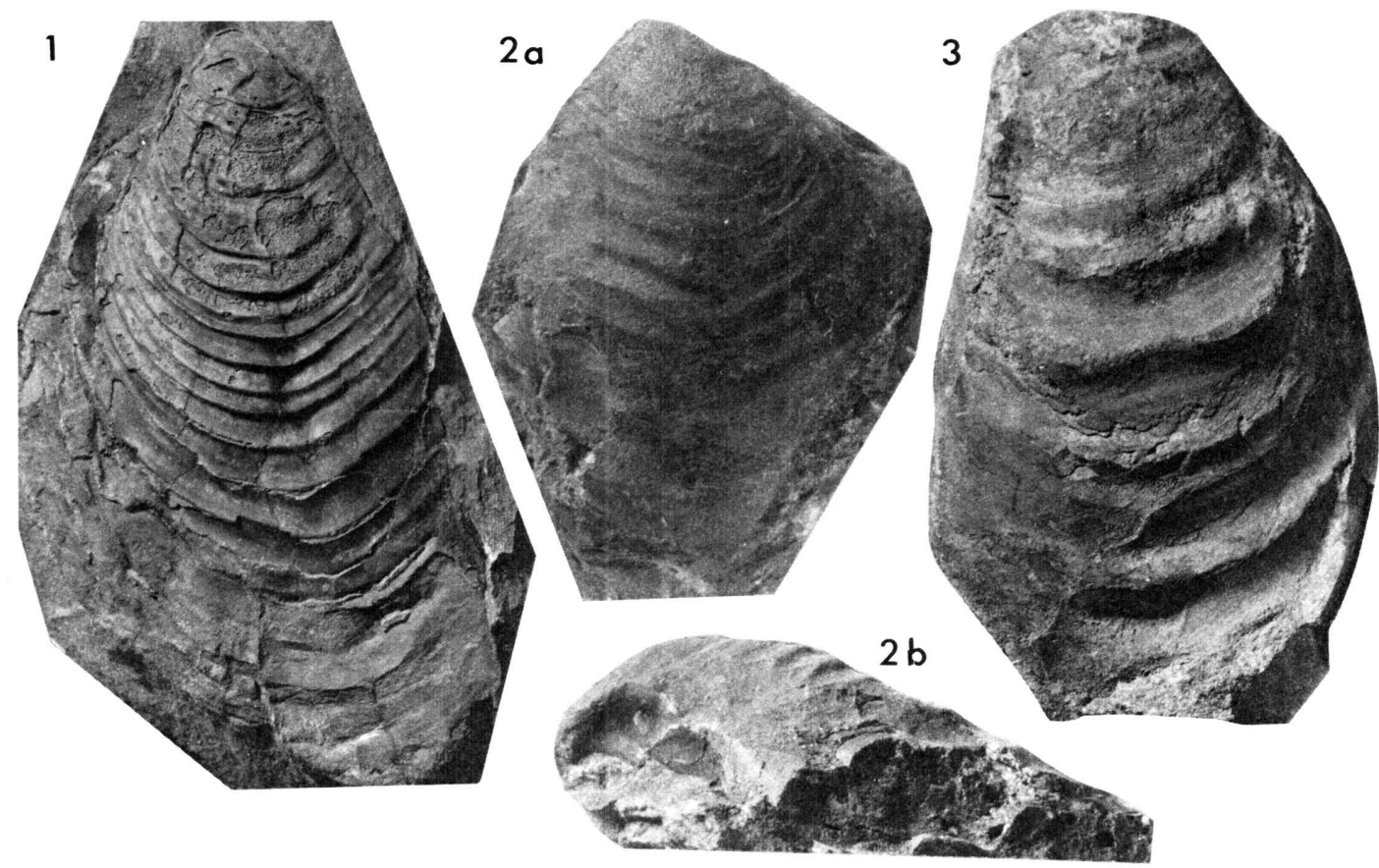

\section{4}

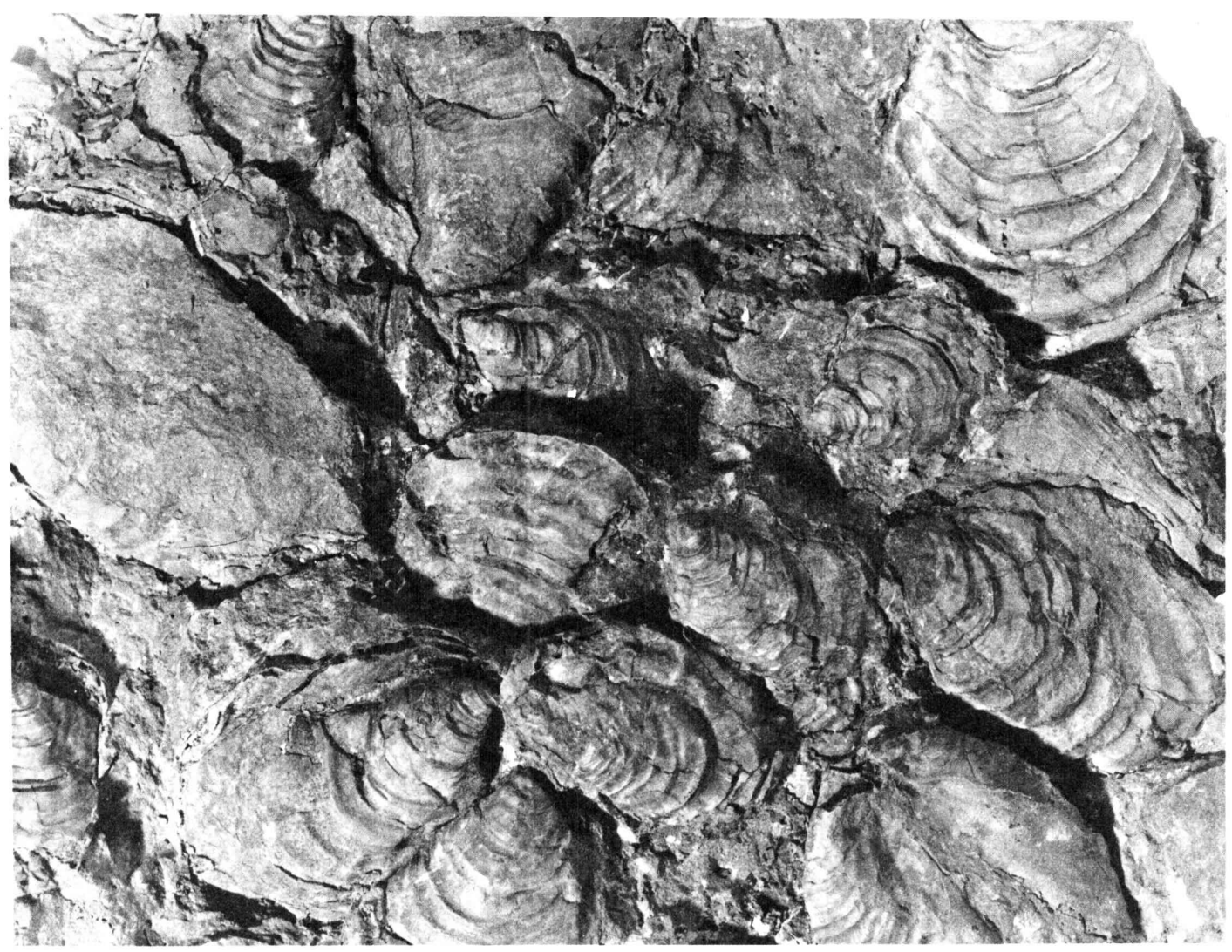

M. NoDA: Succession of Inoceramus in Upper Cretaceous 
phological change of a species as represented by Samples OR242, OR234 and OR233 (and probably also OR230) shows chronoclines despite the apparently persistent litho-facies suggests the influence of other factors which were not recorded in the litho-facies.

3. On the other hand, in the upper part of the sequence, from which Samples UN101, UF101, OI213 and OI214A of Inoceramus uwajimensis were obtained, the litho-facies frequently changes in vertical sequences. This may imply that some minor scale crustal movements were repeated in that age, resulting in frequent environmental changes. The chronological difference in shell morphology was remarkable between Samples OI213 and OI214B. It is noted that in the sequence of litho-facies a number of conspicuous coarse grained rocks intervene between the horizons of OI213 and OI214. We need further study on the materials of other areas for concluding the effect of the environmental change for this change in fossil records.

\section{Conclusion}

1. The specimens from Loc. TA213 are classified into two species. One (represented by Sample TA213A) is identified with Inoceramus teraokai MATsumoto et NODA, which belongs to the stock of Inoceramus labiatus. It disappeared in the Middle Turonian without leaving records of succeeding species in the higher sequences of the Onogawa Group.

2. The other (represented by Sample TA213B) is identified with Inoceramus hobetsensis NAGAO et MATSUMOTO. This species persisted for a certain extent of time interval in the main part of the Turonian. It changed in morphological characters along certain trends in ascending order of sequence, as represented by Samples TA213B, OR242, OR234 and OR233 (and probably also OR230). The principal changes were the broadening in outline (increase in $\mathrm{L} / \mathrm{H}$ ), the enlargement in size, the development of a radial furrow and the appearance and strengthing of nodulous protuberlances on either side of the furrow. The chronoclines in $I$. hobetsensis, if precisely recognized, would be useful for a biostratigraphic subdivision in finer scale.

3. The statistical study on samples from successive horizons would enable us to refine the typological classification. Inoceramus hobetsensis for instance, can be infraspecifically subdivided into at least two units with certain criteria including the absence or presence of a radial depression. In this respect Samples TA213, OR243 and OR234 probably represent a less evolved stage and Sample

\section{Explanation of Plate 37}

(Figures natural size, unless otherwise stated)

Figs. 1, 2, 4. Inoceramus uwajimensis (YeHARA) .............. Page 253

1. Elongate form without posterior wing-like area. JG. H2072, inner cast of left valve. Loc. OI213 (coll. M. NoDA).

2. Form with large beak angle and weak ornament, foretelling a form Inoc. mihoensis MATSUMOTo. MK027, a: lateral view; b: anterior view, inner cast of left valve. Loc. OI214 (coll. H. YAmamoto).

4. Showing the mode of occurrence. $\times 0.8$. Loc. UN101 (coll. M. NoDA).

Fig. 3. Inoceramus sp. GK. H6951. Inner cast of left valve. Loc. OI213 (coll. S. SATO). 


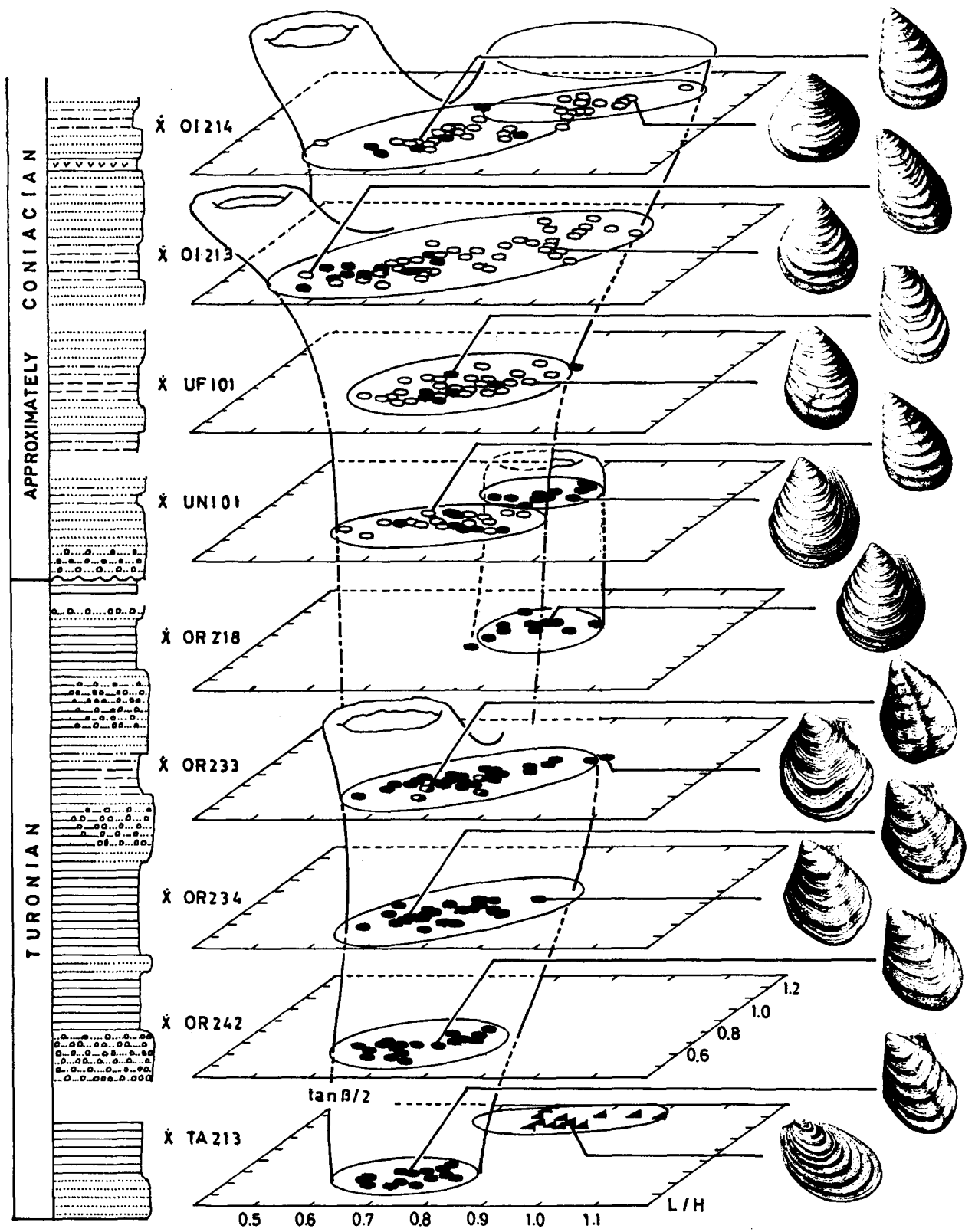

Fig. 22. Diagramatic illustration of the succession of Inoceramus from the Upper Cretaceous of Southwest Japan, with some interpretation of the phylogeny. 
OR233 a more advanced stage in the phylogenetic series of Inoceramus hobetsensis. I put off, however, the final conclusion of precisely defined infraspecific classification until the materials from other areas are comprehensively examined.

4. The morphological difference between Samples OR233 and OR218 probably indicates that Inoceramus hobetsensis was replaced in the Upper Turonian by Inoceramus teshioensis NAGAo et MATSUMOTO of an unrelated stock.

5. Sample UN101, from the available lowest horizon of the Coniacian sequence, consists of specimens of two species. One (represented by UN101B) is intimately related to Sample OR218 of the Upper Turonian Inoceramus teshioensis and the other (UN101A) can be linked with Sample UF101 of the next horizon, being referred to Inoceramus uwajimensis (YEHARA). The derivation of this species is uncertain as far as the material from Southwest Japan is concerned, because Sample UN101A is not related to any sample from a lower horizon in the examined sequence.

6. Specimens of Samples UN101A, UF101, OI213 and OI214 are all referred to Inoceramus uwajimensis. This species includes a form with posterior wing-like area, but taxonomically this form is hardly discriminated from the typical form, because they are both coexistent at every horizon as far as the examined samples from Southwest Japan are concerned.

7. As revealed by analyses of successive samples, Inoceramus uwajimensis shows the change of shell characters in various directions, expanding the extent of variation with time, Sample OI214 is divided into two groups. One is a form with a larger beak angle and a fan-shaped outline. This seems to foretell, at least as one of the alternative interpretations, the characters of Inoceramus mihoensis Matsumoto of the next substage (Upper Coniacian). The other form disappears without succeeding species. However, whether Inoceramus mihoensis was really derived from Inoceramus uwajimensis or merely records an incoming of a species from another unrelated stock of different province is open to question.

8. To sum up, the succession of Inoceramus in the Turonian to Coniacian sequences of Southwest Japan is schematically illustrated in Fig. 22. A presumed phylogenetic series is partly shown in the figure.

\section{References}

ASANo, K. (1973) : On the localization and internationalization of zonation. Jour. Geol. Soc. Japan, 79, (8), 557-561 (in Japanese).

FUJIr, K. (1954): Stratigraphy and geological structure of the Usuki area, Oita-Prefecture, Kyushu (1). Ibid., 60, (709), 413-427 (in Japanese with English abstract).

Hayami, I. (1967) : Principles and methods of systematic palaeontology with special reference to fossil bivalves. part 2. Fossils, (13), 39-52 (in Japanese). (1969): Notes on Mesozoic "planktonic" bivalves. Jour. Geol. Soc. Japan, 75, (7), 375-385 (in Japanese with English abstract).

(1969) : Mensuration of fossils and statistics-an example of palaeontological exercise-Sci. Rept. Fac. Sci. Kyushu Univ., [D], 10, (2), 67-90 (in Japanese with English abstract).

(1973): An evolutional interpretation of biostratigraphic zones. Jour. Geol. Soc. Japan, 79, (3), 219-235 (in Japanese with English abstract).

Hayami, I. and Matsukuma, A. (1972) : Mensuration of fossils and statistics.-Analysis of allometory and variation-Sci. Rept. Fac. Sci. Kyushu Univ., [D], 10, (3), 
p. 135-160 (in Japanese with English abstract).

HeINe, F. (1929): Die Inoceramen des mittelwestfälischen Emschers und unteren Untersenons. Abh. Preuss. Geol. Landesanst., Neue Folge, (120), 1-20.

Јімво, K. (1894) : Beiträge zur Kenntniss der Fauna der Kreide Formation von Hokkaido. Palaeont. Abhand., Neue Folge, 2, (3), 1-48, pl. 1-9.

Kotaka, T. (1953) : Variation of Japanese Anadara granosa. Trans. Proc. Palaeont. Soc. Japan, [N. S.], (10), 31-36, pl. 4.

Kudo, A. (1969) : Cretaceous system of the Uwajima area, Ehime Prefecture. Jour. Geol. Soc. Japan, 55, (648-649), 117 p. (in Japanese).

Matsumoto, T. (1936): Geology of the Onogawa basin, Kyushh. Ibid., 43, (517-518), 758-786, 815-852 (in Japanese with English abstract).

(1954) : Matsumoto, T. ed. The Cretaceous system in the Japanese islands. 241 pp. Japan Sci. Promot. Sci. Ueno, Tokyo.

(1957): Inoceramus mihoensis n. sp. and its significance. Mem. Fac. Sci., Kyushu Univ., [D], 6, (2), 65-68, pl. 21.

(1959) : Zonation of the Upper Cretaceous in Japan. Ibid., 9, (2), 55-93.

(1963) : Matsumoto, T. ed. A survey of the fossils from Japan illustrated in classical monobraphs. part 10, p. 60-68. Palaeont. Soc. Japan.

(1969): Study on the Cretaceous ammonite of Circum-Pacific region. Japanese Scientific Manthly, 22, (6), 7-17 (in Japanese).

Matsumoto, T. and NodA, M. (1968) : An interesting species of Inoceramus from the Upper Cretaceous of Kyushu. Trans. Proc. Palaeont. Soc. Japan, [N. S.], (71), $317-325$, pl. 32.

(1975): Notes on Inoceramus labiatus (Schlotherm) from Hokkaido. Ibid., (in print).

Matsumoto, T. and Ueda, Y. (1962) : in Ueda, The type Himenoura Group. Appendices Palaeontological Notes. Mem. Fac. Sci. Kyushu Univ., [D], 12, (2), 129-178, pls. 22-27.

MAYR, E., LINSLEY, E. G. and Usinger, R. L. (1953) : Methods and principles of systematic zoology. 336 pp, Mc Graw-Hill Book Company, INC. New-York.

MüLLER, G. (1888): Beiträge zur Kenntniss der Kreide am nordlichen Harzrands. Jahrbuch der König. Preussischen Geologischen Landesanstadt und Bergakademiein Berlin des Jajr 1887, Berlin 1888 (actual date of issue), 372-456, pls. $16-18$.

NAGAo, T. (1935) : A giant of Inoceramus. Warerano Kobutsu, 4, 197-199, pl. 1.

NAGA0, T. and MATSUmoto, T. $(1939,1940)$ : A monograph of the Cretaceous Inoceramus of Japan. part I, Jour. Fac. Sci. Hokkaido Imp. Univ., [4], 5, (3-4), 241-299, pls. 23-34 : part II, Ibid., 6, (1), 1-64, pls. 1-22.

NodA, M. (1969): Biostratigraphic study of the Onogawa Group, Kyushu. Sci. Rept. Fac. Sci. Kyushu Univ., [D], 10, (1), 1-10, pls. 1-3 (in Japanese with English abstract).

(1971): Cretaceous Inoceramus from the Onogawa Group and the Tano Formation, Central Kyushu. Sci. Rept. Oita, (25), 24-34, pls. 1-3 (in Japanese).

OватA, I. (1969) : Note on the upper limit of the Cretaceous Futaba Group. Jour. Geol. Soc. Japan, 73, (9), 443-444 (in Japanese).

Obata, I. and Suzuki, T. (1971): Additional note on the upper limit of the Cretaceous Futaba Group. Ibid., 75, (8), 443-445 (in Japanese).

OINomikado, T. (1936): Conchometrical research on the fossil Anadara granosa (LINNE). Vinus, 6, (3), 135-146.

SAITo, T. (1962) : The Upper Cretaceous system of Ibaraki and Fukushima Prefectures, Japan (part I). Bull. Fac. Art. Sci. Ibaraki Univ., [Nat. Sci.], (13), 51-88, pl. 108.

Seitz, O. (1961): Die Inoceramen des Santon von Nordwestdeutschland. Beih, Geol. Jb. (46), p. 1-186, pls. 1-15. 
(1965) : Die Inoceramen des Santon und Unter-Campan von Nordwestdeutschland. Ibid., (69), 1-194, pls. 1-26.

(1967) : Die Inoceramen des Santon und Unter-Campan von Nordwestdeutschland. Ibid., (75), 1-171, pls. 1-27.

(1970): Unter einige Inoceramen aus der oberen Kreide. Ibid., (86), 1-171, pls. $1-28$.

SyLvester, B. (1951): The subspecies in palaeontology. Geol. Mag., 88, 88-102.

TAKAI, Y. and MATSumoto, T. (1961): Cretaceous-Tertiary unconformity in Nagashima, Southwest Kyushu. Mem. Fac. Sci. Kyushu Univ., [D], 11, (2), 257-278, pls. 11-12.

TANABE, K. (1972): Stratigraphy and the Cretaceous formation in the Uwajima district, Ehime Prefecture, Shikoku. Jour. Geol. Soc. Japan, 78, (4), 177-190 (in Japanese with English abstract).

(1973) : Evolution and mode of life of Inoceramus (Sphenoceramus) naumanni Yokoyama emend., an Upper Cretaceous bivalve. Trans. Proc. Palaeont. Soc. Japan, [N. S.], (92), 163-184, pls. 27-28.

TERAOKA, Y. (1970): Cretaceous formation in the Onogawa basin and its vicinity, Kyushu, Southwest Japan. Rept. Geol. Surv. Japan, (237), 1-84, pls. 1-18 (in Japanese with English abstract).

Woons, H. (1912): The evolution of Inoceramus in the Cretaceous period. Q.J.G.S. London, 68, 1-20.

YABE, H. and NAGAO, T. (1925): New or little known Cretaceous fossils from North Saghlien. Sci. Rept. Tohoku Imp. Univ., [4], 7, (4), 111-124, pls. 28-29.

YeharA, S. (1924) : On the Izumi sandstone group in the Onogawa basin, Prov. Bungo, and the same group in Uwajima, Prov. Iyo. Jap. Jour. Geol. Geogr., 3, 24-40, pls. $2-4$.

Yokoyama, M. (1890) : Verstein Japan, Kreide. Palaeontographica, 36, 159-202, pls. 18-25. 